\title{
1. CENOZOIC AND MESOZOIC SEDIMENTS FROM THE PIGAFETTA BASIN, LEG 129, SITES 800 AND 801: MINERALOGICAL AND GEOCHEMICAL TRENDS OF THE DEPOSITS OVERLYING THE OLDEST OCEANIC CRUST ${ }^{1}$
}

\author{
Anne Marie Karpoff ${ }^{2}$
}

\begin{abstract}
Sites 800 and 801 in the Pigafetta Basin allow the sedimentary history over the oldest remaining Pacific oceanic crust to be established. Six major deposition stages and events are defined by the main lithologic units from both sites. Mineralogical and chemical investigations were run on a large set of samples from these units. The data enable the evolution of the sediments and their depositional environments to be characterized in relation to the paleolatitudinal motion of the sites. The upper part of the basaltic crust at Site 801 displays a complex hydrothermal and alteration evolution expressed particularly by an ochre siliceous deposit comparable to that found in the Cyprus ophiolite. The oldest sedimentary cover at Site 801 was formed during the Callovian-Bathonian (stage 1) with red basal siliceous and metalliferous sediments similar to those found in supraophiolite sequences, and formed near an active ridge axis in an open ocean. Biosiliceous sedimentation prevailed throughout the Oxfordian to Campanian, with rare incursions of calcareous input during the middle Cretaceous (stages 2, 4, and 5).

The biosiliceous sedimentation was drastically interrupted during the Aptian-Albian by thick volcaniclastic turbidite deposits (stage 3). The volcanogenic phases are pervasively altered and the successive secondary mineral parageneses (with smectites, celadonite, clinoptilolite, phillipsite, analcime, calcite, and quartz) define a "mineral stratigraphy" within these deposits. From this mineral stratigraphy, a similar lithologic layer is defined at the top of the Site 800 turbidite unit and the bottom of the Site 801 turbidite unit. Then, the two sites appear to have been located at the same distal distance from a volcanic source (hotspot). They crossed this locality, at about $10^{\circ} \mathrm{S}$, at different times (latest Aptian for Site 800 , middle Albian for Site 801).

The Cretaceous siliceous sedimentation stopped during the late Campanian and was followed by deposition of Cenozoic pelagic red clay (stage 6). This deep-sea facies, which formed below the carbonate compensation depth, contains variable zeolite authigenesis in relation to the age of deposition, and records the global middle Cenozoic hiatus events. At the surface, the red clay from this part of the Pacific shows a greater detrital component than its equivalents from the central Pacific deep basins.
\end{abstract}

\section{INTRODUCTION}

The Pigafetta Basin in the western Pacific Ocean is an elongated, deep oceanic basin within the Jurassic quiet zone, surrounded by seamount chains: the Magellan to the west-southwest and the MarcusWake to the north-northeast. The main objective of Leg 129 was to recover the oldest oceanic crust (predicted to be Middle Jurassic from the Mesozoic magnetic anomaly sequence) and the overlying deepsea pelagic sediments (Lancelot, Larson, et al., 1990). These deposits chronicle the paleoenvironment of the "superocean" at that time. Two sites were drilled: Site 800, 40 miles northeast of Himu Seamount on magnetic lineation M $33\left(21^{\circ} 55.38^{\prime} \mathrm{N}, 152^{\circ} 19.37^{\prime} \mathrm{E}, 5686 \mathrm{~m}\right.$ water depth) and Site 801 , in the central part of the basin $\left(18^{\circ} 38.57^{\prime} \mathrm{N}\right.$, $156^{\circ} 21.57^{\prime} \mathrm{E}, 5673 \mathrm{~m}$ water depth), on a magnetic quiet zone southeast of the M25-M37 magnetic lineation sequence (Fig. 1). Site 801, with three drill holes, is the first site ever to recover CallovianBathonian sediments and crust from the Pacific plate. Before drilling at Site 801, the previous attempts to recover Jurassic sediments in this area have failed in chert, thick volcaniclastic deposits of Cretaceous age (Deep Sea Drilling Project, or DSDP, Sites 461 and 585), and thick lavas flows, such as the volcanic sills of Early Cretaceous age at Site 800 .

The sedimentary facies at both Sites 800 and 801 resulted from two main types of input: predominantly biosiliceous oozes and associated pelagic clays, which experienced different degrees of diagenesis, and volcaniclastics related to the middle Cretaceous volcanic event. The mixture of these phases, in variable proportions, forms

\footnotetext{
'Larson, R. L., Lancelot, Y., et al., 1992. Proc. ODP, Sci. Results, 129: College Station, TX (Ocean Drilling Program).

${ }^{2}$ Centre de Géochimie de la Surface-C.N.R.S., 1 rue Blessig, 67084 Strasbourg Cedex, France.
}

several sedimentary units which can be correlated between sites, although these units are sometimes diachronous.

Thus, a synthetic and composite sequence has been established for this area of the Pacific Ocean, with several deposition episodes or events since the Middle Jurassic. The purpose of the present study is to establish the main mineralogical and chemical characteristics of the successive deposits, and to characterize the dissimilarity between the two sites and the possible influence of the volcaniclastic input and underlying basaltic crust on the diagenetic evolution and chemical composition of the biogenic sediments. The mineralogical and geochemical characterization of the sedimentary sequence over the oldest remaining Pacific crust can be used as a reference section, as is necessary for any further comparison with the equivalent sections from the Jurassic superocean and Mesozoic oceanic realm, such as Tethyan supraophiolite sequences. The Cenozoic condensed sediments are compared to the equivalent red clays from central Pacific deep basins.

\section{SEDIMENTARY SEQUENCES FROM SITES 800 AND 801}

The sedimentary sequences penetrated at Site 800 and Site 801 consist predominantly of pelagic clay, chert and porcellanite, limestone, volcaniclastic deposits, and siliceous red claystone as basal sediments. The stratigraphic sequences, ages, petrographic and major mineralogical compositions of the facies and their physical properties, sedimentation rates curves, and seismic stratigraphy are detailed in Lancelot, Larson, et al. (1990).

\section{Site 800}

The sedimentary column has been divided into five units, from top to bottom, above a massive dolerite unit (498.1-544.5 mbsf) (Fig. 2): 


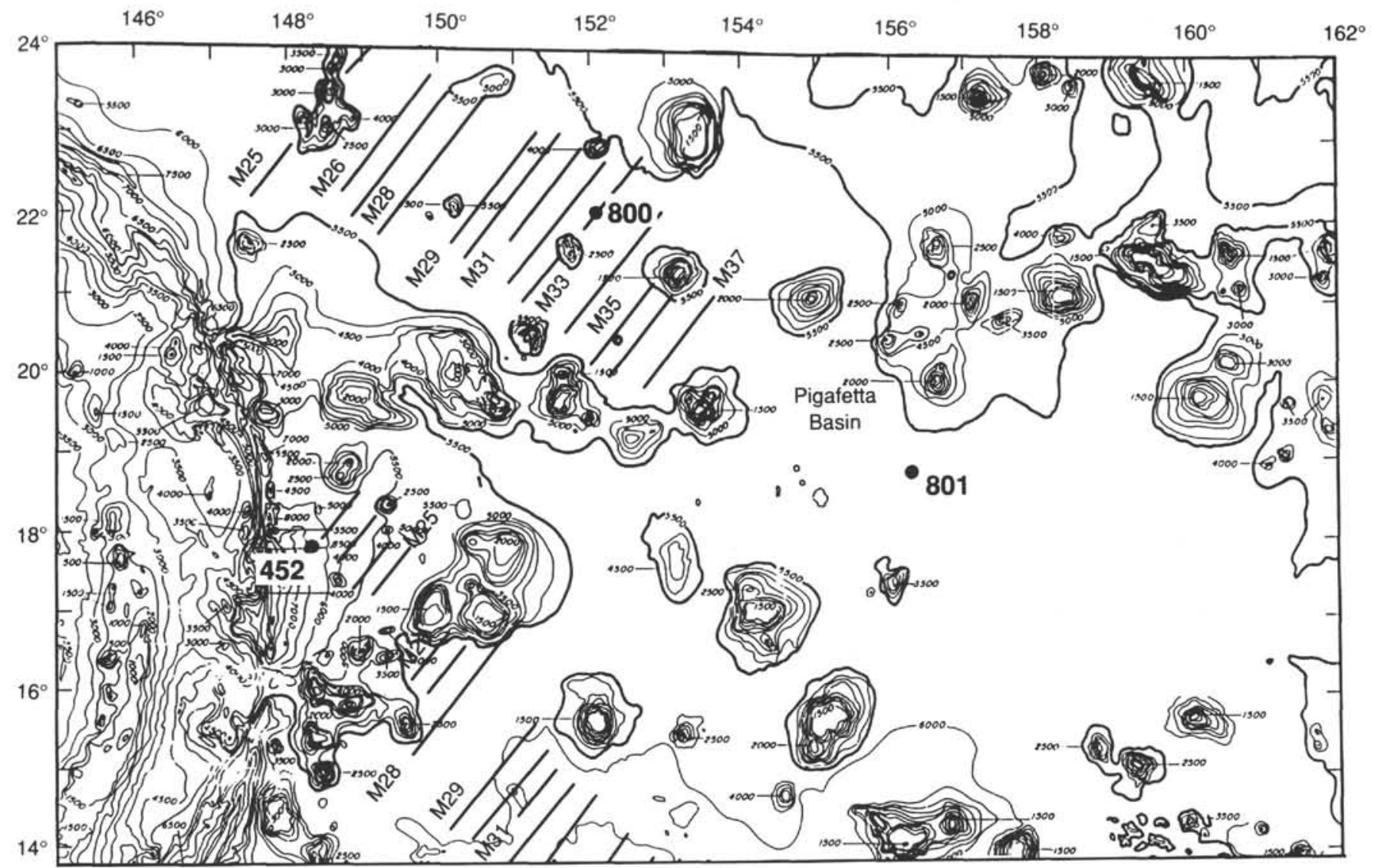

Figure 1. Location map of Sites 800 and 801, Pigafetta Basin, western Pacific Ocean. Bathymetry in meters of the central western Pacific Ocean; main magnetic anomalies and location of DSDP and ODP drill sites (from Lancelot, Larson, et al., 1990).

Unit I: 0-38.0 mbsf, Tertiary (Pliocene) to upper Campanian zeolitic pelagic brown clay.

Unit II: $38.0-78.2$ mbsf, upper Campanian to Turonian brown chert and porcellanite.

Unit III: 78.2-228.6 mbsf, Cenomanian to lower Albian gray chert and silicified limestone, grading into nannofossil chalk at the base of the sequence.

Unit IV: 228.6-449.6 mbsf, Aptian redeposited volcaniclastics with spectacular turbidite and debris-flow features.

Unit V: 449.6-498.1 mbsf, Hauterivian to Berriasian laminated red claystone with hard chert at the base.

\section{Site 801}

The stratigraphic sequence at Site 801 is subdivided into six units, from top to bottom (Fig. 2):

Unit I: 8.0-64.0 mbsf, Tertiary (Pliocene) to upper Campanian zeolitic pelagic brown clay, with a thin interval of calcareous ooze.

Unit II: 64.0-126.5 mbsf, Campanian to Turonian brown chert and porcellanite.

Unit III: 126.5-318.3 mbsf, Cenomanian and Albian volcaniclastic turbidites with minor radiolarite near the base.

Unit IV: 318.3-442.9 mbsf, Lower Cretaceous to Upper Jurassic brown radiolarite and manganiferous dark brown chert. Two subunits were distinguished on the basis of the relative abundance of chert and clay: Subunit IVA is clay-poor radiolarite with abundant chert (Valanginian-upper Tithonian) and Subunit IVB is clay-rich radiolarite (upper Tithonian-Oxfordian).

Unit V: 442.9-461.6 mbsf, Callovian-Bathonian umber-colored radiolarite and siliceous claystone.
Unit VI: 461.6-590.9 mbsf, Middle Jurassic basement, lava flows and pillows basalt (alkalic and tholeiitic basalt) with interbedded silicified claystone and a hydrothermal deposit.

\section{STAGES OF THE SEDIMENTARY HISTORY OF THE WESTERN PACIFIC}

Sedimentary history begins during the Middle Jurassic at Site 801 . Sites 800 and 801 show comparable successions of pelagic facies through time since the Early Cretaceous. Biogenic sedimentation, dominantly siliceous, was masked during the Cretaceous by the abundant input of volcaniclastic material from the building of numerous volcanic edifices.

Six main deposition stages and events above the basaltic basement (sampled at Site 801) are defined here, and have been established from the sedimentary record, physical properties, and compiled petrographic, macroscopic, and microscopic descriptions, and from the preliminary mineralogical investigations of the facies (Shipboard Scientific Party, 1990a, 1990b); these stages are confirmed by the mineralogical and geochemical data acquired for this study (Fig. 2).

\section{The Jurassic Basement}

The cored crustal sequence at Site 801, from 461.6 to 590.9 mbsf, consists of alkalic basalt overlying tholeiitic basalt. Pillow basalt is first identified at $495.0 \mathrm{mbsf}$. Several thin sedimentary layers were recovered in the upper part of the sequence interbedded with thin basalt flows. These deposits are mainly silicified claystone, chert, and recrystallized limestone. At $521.7 \mathrm{mbsf}, 60 \mathrm{~m}$ below the top of the basement, a remarkable chrome yellow siliceous hydrothermal layer 


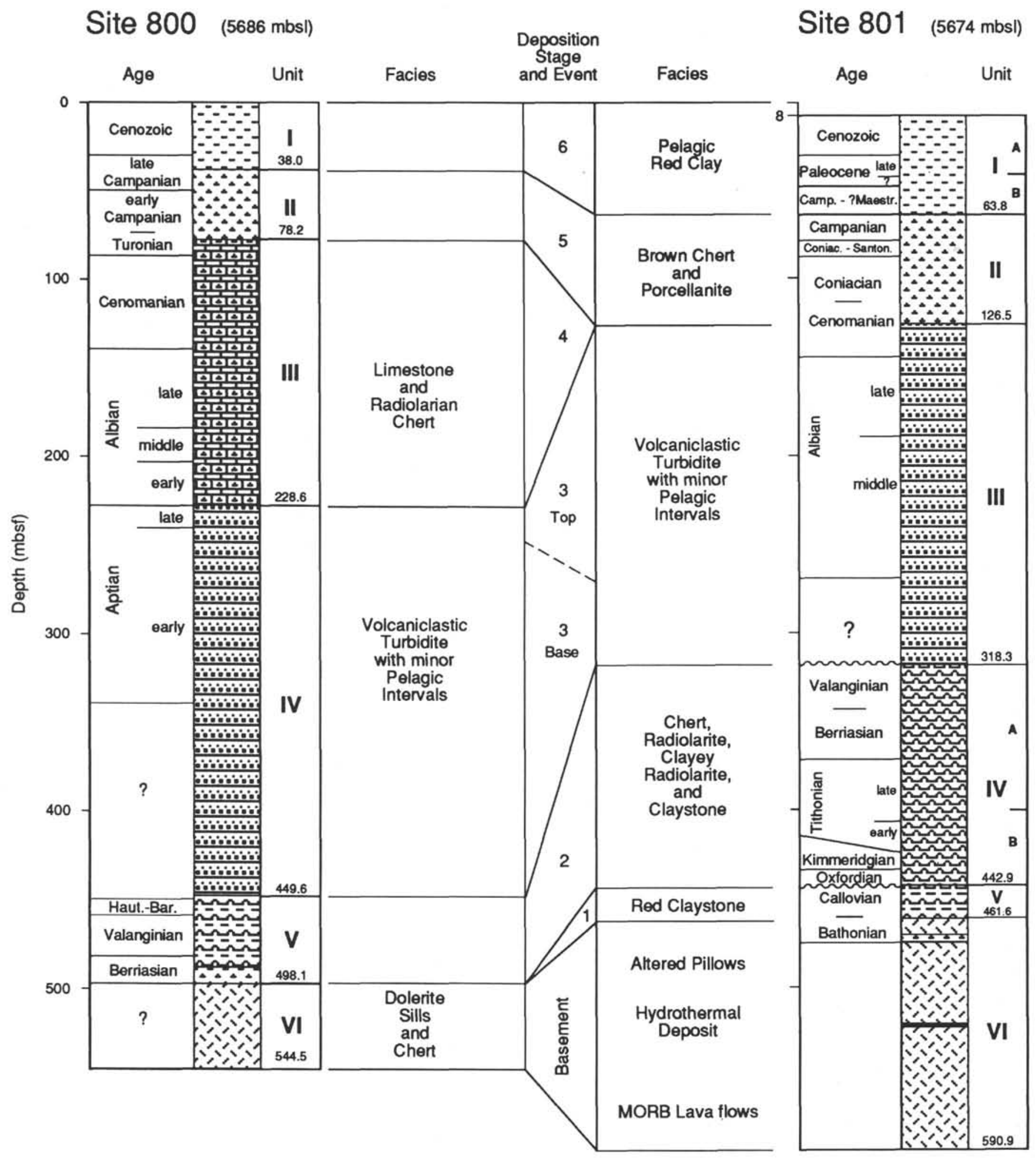

Figure 2. Composite lithologic units described at Sites 800 and 801 (from Lancelot, Larson, et al., 1990) and equivalent deposition episodes (stages 1 to 6) established in this paper. 
(of which $2.64 \mathrm{~m}$ were recovered) overlies extremely altered pillow basalt. The textural description of this interval established a possible sequence of formation events: deposition of colloids as spherical bodies, evolution of this primary material by recrystallization, and rapid invasion of silica-rich fluids with the crystallization of quartz (Shipboard Scientific Party, 1990b). Aphyric tholeiitic basalt flows become less altered downhole (Alt et al., this volume).

Samples from the basalt interval are used as mineralogical and chemical references; they are metasediment lenses, hydrothermal deposits, and interpillows and alteration materials.

\section{Stage 1: Callovian-Bathonian Basal Sedimentation}

The oldest sediments overlying the Jurassic basaltic crust are vivid red radiolarite and hematitic claystone, with common manganese coatings along silica-filled fractures. This 18 -m-thick facies was recovered only at Site 801 (Unit V). The age given by the siliceous fauna is Callovian-Bathonian to basal Oxfordian (Matsuoka, this volume). The more or less rhythmic interbedding between $\mathrm{Si}$-rich and clayey end-members is tentatively interpreted by Molinie and Ogg (this volume) to result from Milankovitch cycles; the contrast can also be related to bottom-current winnowing, episodic high iron input, differential silica dissolution, or diagenetic evolution. A characteristic of these deposits, buried below $442 \mathrm{~m}$ of sediments, is their relatively low compaction, with a porosity of $46 \%$. Another peculiarity is an apparent dip of about $30^{\circ}$. The estimated sedimentation rate for these deposits is about $3 \mathrm{~m} / \mathrm{m}$.y., relatively low compared to the rate of pelagic clays and siliceous oozes $(1-10 \mathrm{~m} / \mathrm{m} . \mathrm{y}$; references in Kennett, 1982; Karpoff, 1989).

\section{Stage 2: Oxfordian-Tithonian and Berriasian-Barremian Biosiliceous Sedimentation}

A probable hiatus marks the lithologic boundary between Callovian red radiolarite and Oxfordian-Tithonian brown clayey radiolarite (Subunit IVB at Site 801). The sediments grade upward to a more homogeneous siliceous deposit. The facies is characterized by mottling, burrows, and laminations. Millimetric manganese micronodules occur scattered or along the laminated stratification. Varicolored dark brown chert occurs as lenses. The transition between lower Tithonian clayey radiolarite with abundant manganese micronodules to upper Tithonian cherty radiolarite appears to be sharp. Intensively brecciated radiolarian chert with numerous quartz-filled fractures occurs in the poorly recovered upper Tithonian section.

The Berriasian-Hauterivian deposits show small-scale variations in the relative radiolarian concentration and in the development of the diagenetic silicification to porcellanite and chert (Behl and Smith, this volume). Partially coeval deposits occur at Sites 800 and 801 (basal Unit V at Site 800 and Subunit VIA at Site 801) with some dissimilarities. At Site 800, the facies is microlaminated clayey radiolarite-a regular alternation of light-colored radiolarian-rich layers and dark red claystone layers, with an apparent cyclicity. At Site 801, the radiolarite displays an irregular, fine lamination, and vague rhythmic banding. Within both sections, fine silica-filled fractures are common and thin manganese coatings occur over the laminations.

The clayey radiolarite from the Oxfordian-Kimmeridgian and Berriasian-Valanginian sections have an average porosity about $42 \%$, in contrast to that of the Tithonian chert $(<5 \%)$, and this value is slightly lower than that from the underlying basal red radiolarite. The estimated average sedimentation rate is low, about $2-5 \mathrm{~m} / \mathrm{m}$.y., for Oxfordian to early Barremian deposition as a whole (Site 801). The upper Tithonian section corresponds to the more siliceous sediments with the apparently higher sedimentation rate of about $10 \mathrm{~m} / \mathrm{m} . \mathrm{y}$.

\section{Stage 3: Middle Cretaceous Volcanic Event and Sedimentation}

The deposition of the thick volcaniclastic turbidites occurred at Site 800 (Aptian, Unit IV) before that at Site 801 (Albian-Cenomanian, Unit III), with a slight overlap, indicating that most of the volcaniclastic deposition was diachronous (Fig. 3). This diachronism could result from different volcanic sources, from successive pulses from the same source, or even from the deferred migration of both sites over the same location with respect to a fixed source (hotspot). The later possibility is suggested from the mineralogical facies (as described below). The massive redeposition of volcanogenic material masked the biogenic sedimentation background, often making the age diagnosis difficult. Further, possible hiatuses could have occurred during the Hauterivian-Barremian and at the Aptian/Albian boundary (Site 800 ) or during the Barremian-Aptian (Sites 800 and 801). The scarce biogenic input is mainly siliceous and calcareous. The occurrence of shallow-water fossils in some intervals indicates the proximity to the source, possibly a volcanic edifice. Facies are mainly debris flows, thick turbidites with upward-fining beds (over $4 \mathrm{~m}$ thick in the Albian section at Site 801), and debrites; ripple and cross laminations, breccia horizons, redox fronts, bioturbation features, clay-filled fractures, or calcite veins are common (Shipboard Scientific Party, 1990a, $1990 \mathrm{~b}$; Salimulah and Stow, this volume). In places, the degree of alteration of the volcaniclastic phases, both in sandstone as well as claystone, is relatively high, expressed by the occurrence of palagonite and zeolites in a green clay matrix. The measured porosities vary from $65 \%$ to $32 \%$. The sedimentation rate is estimated to be $5 \mathrm{~m} / \mathrm{m}$.y. (minimum for the section at Site 801 ) and $35 \mathrm{~m} / \mathrm{m}$.y. (maximum for the section at Site 800 ), with an average rate of about $12 \mathrm{~m} / \mathrm{m}$.y.

\section{Stage 4: Albian-Cenomanian Pelagic Sedimentation}

At Site 800 Albian-Cenomanian deposits coeval with the volcaniclastic sequence from Site 801 are radiolarian chert and limestone (Unit III). The calcareous and siliceous contributions become progressively more abundant over the latest volcanogenic input still present at the base of the unit. The biogenic facies, with the association of radiolarians, foraminifers, and nannofossils, reveals the high fertility of the surface water masses. Diagenesis created a full range of various lithologies between chalk and chert (Shipboard Scientific Party, 1990a; Behl and Smith, this volume). The locally well-compacted sediments ( $38 \%$ to $7 \%$ porosity) were deposited with an average sedimentation rate of $6 \mathrm{~m} / \mathrm{m}$.y.

\section{Stage 5: Late Cretaceous Siliceous Sedimentation}

At both sites, during the Turonian to late Campanian, deposits were predominantly biosiliceous and iron-rich, with a relatively low sedimentation rate $(3 \mathrm{~m} / \mathrm{m}$.y. in Unit II at Sites 800 and 801$)$. Diagenetic transformation has lead to formation of porcellanite and chert with low porosity (25\%). These Upper Cretaceous facies are widespread in the northwestern Pacific (Pisciotto, 1981); the same stratigraphic sequence, with overlying red clay, was recovered at northern DSDP Site 198 (Heezen and MacGregor, 1973).

\section{Stage 6: Latest Cretaceous to Quaternary Red Clay Deposition}

The pelagic dark brown clay lying over both sedimentary sequences at Sites 800 and 801 (Unit I) is similar to that recovered elsewhere in the abyssal basins (Karpoff, 1989, and references therein). This muddy facies (water content $50 \%$ to $84 \%$ ) is composed of clay minerals, zeolites, and 
Age

\section{0}

$\mathrm{Ma}$

Q uaternary $\overline{\text { Pliocene }}{ }^{0} \mathrm{Ma}$

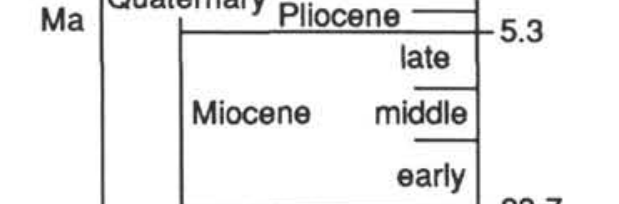

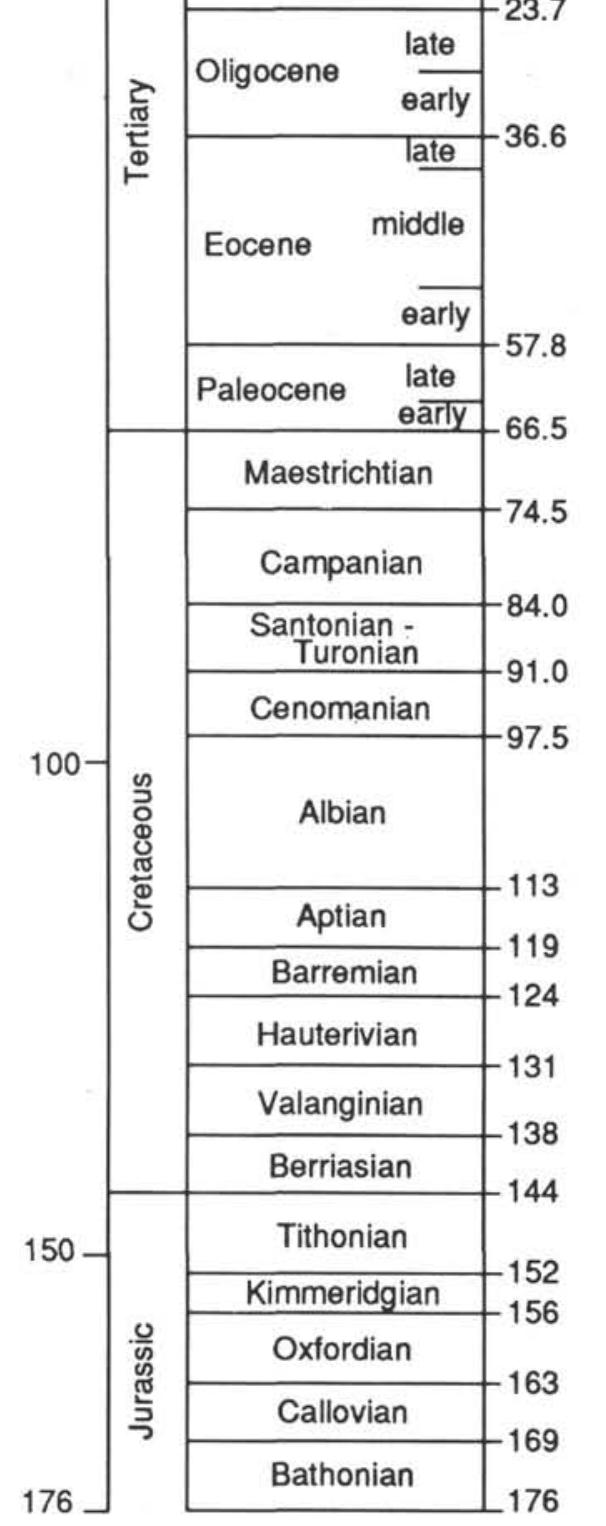

Site 800

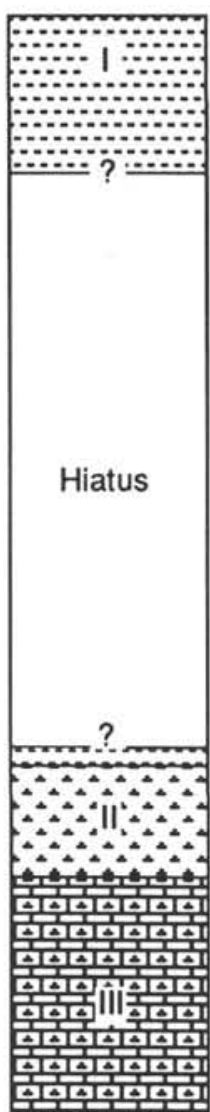

Hiatus

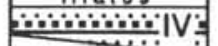

Hiatus?
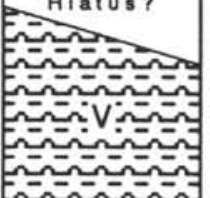

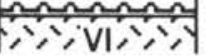

?
Site 801

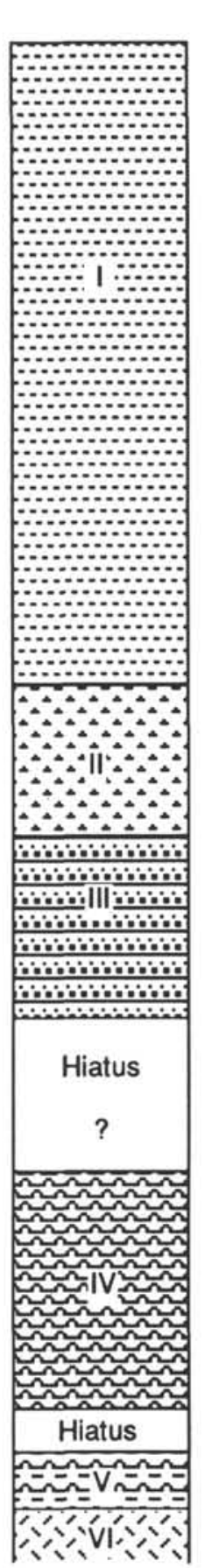

Paleolatitudes

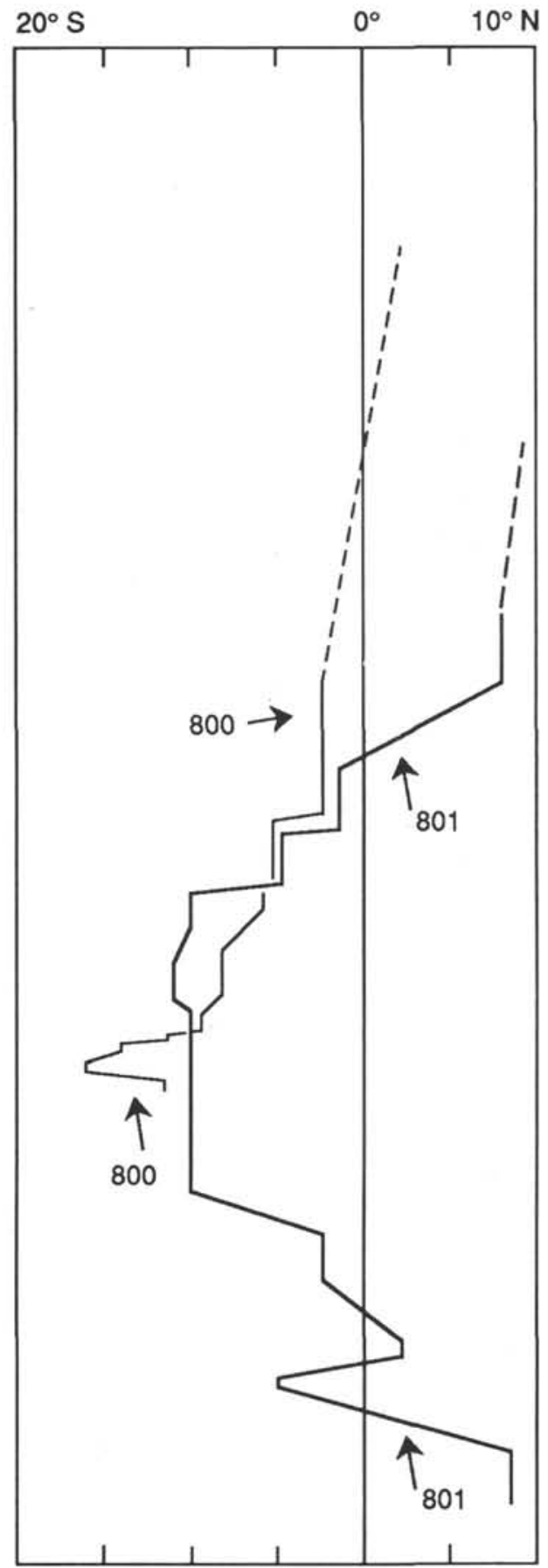

Figure 3. Age correlation for Sites 800 and 801 (lithologic symbols same as in Fig. 2) and paleolatitudes vs. time at both sites (data from Lancelot, Larson, et al., 1990). Time scale from Palmer (1983) and Kent and Gradstein (1985).

iron oxyhydroxides and manganese micro-nodules, resulting from early diagenesis; it is related to very slow sedimentation $(0.5 \mathrm{~m} / \mathrm{m}$.y.) below the carbonate compensation depth (CCD). At Site 801 the red clay unit is interrupted by $45 \mathrm{~cm}$ of a nannofossil ooze layer with a mixed fauna giving a latest Cretaceous to late Paleocene age. In the red clay facies, the rare, poorly preserved, and often mixed fauna tentatively corroborates the existence of several successive hiatuses during these times. The main and widespread Cenozoic hiatuses observed in the Pacific realm are at the Eocene-Oligocene boundary, in the middle Miocene, and at the base of the lower Pliocene; these events are related to tectonic events and motion of the Pacific plate and subsequent oceanic responses, including the dynamics of water masses and productivity (Karpoff, 1989). 
The age correlation diagram for Sites 800 and 801 also illustrates the diachronism of the deposition of the equivalent facies and the similarity of the sedimentary histories (Fig. 3). For both sites, the curves of the recorded paleolatitudes vs. time (from shipboard data in Lancelot, Larson, et al., 1990) also show that the periods of more biosiliceous sedimentation correlate to the subequatorial position of the sites (1) during late Oxfordian to Tithonian, stage 2, Site 801Unit IV, and (2) during the Cenomanian to Campanian, late stage 4 and stage 5, Site 800-Units II and III, and Site 801-Unit II. These episodes also correspond to the highest average sedimentation rates (estimated for compacted sediments), such as the Tithonian section at Site 801 , or with the highest primary productivity (siliceous and calcareous), such as the Cenomanian section at Site 800 .

Following identification of the sequence of deposition stages presented above, mineralogical and geochemical investigations on the deposits were conducted for both sites. These analyses allow the specific features of the deposits at each site and the trends of the sedimentary evolution (deposition and subsequent diagenesis) of the Pigafetta Basin to be defined. The studied samples are representative of the whole set of recovered lithologies. Although recovery was poor, some dense facies (i.e., chert and silicified limestone) and the missing material in these units were probably softer clayey or chalky facies (Fisher et al., this volume). The samples taken may represent the variety present in the complete section. The main lithological characteristics of the samples are given in Tables 1 and 2 .

\section{ANALYTICAL PROCEDURES}

\section{Mineralogical Investigations}

Routine X-ray diffraction (XRD) analyses were made on bulk powdered samples and on individual fragments using a Phillips PW1710 diffractometer. Samples were run between $3^{\circ}$ and $65^{\circ} 2 \theta$ at $40 \mathrm{kV} / 20 \mathrm{~mA}$, using $\mathrm{CuK} \alpha$ radiation, $\mathrm{Ni}$ filter, and a scan speed of $1 \% \mathrm{~min}$. For some samples, the clay fraction $(<2 \mu \mathrm{m})$ was separated and an XRD analysis was run on four types of oriented aggregates: (1) untreated, (2) ethylene-glycol treated, (3) hydrazine treated, and (4) heated $\left(4 \mathrm{hr}\right.$ at $\left.490^{\circ} \mathrm{C}\right)$. The following diffractometer conditions were used for clay extractions: $\mathrm{CoK} \alpha$ radiation, Fe filter, $40 \mathrm{kV} / 20 \mathrm{~mA}$, $0.2^{\circ}-1^{\circ}$ slits, and $1^{\circ} 2 \theta / \mathrm{min}$ scan speed. A few unoriented clay fractions were also run under the powdered XRD conditions in order to confirm the $\{060\}$ diffraction peak position, allowing discrimination of dioctahedral and trioctahedral smectites. The untreated clay fraction was also studied under a Phillips EM300 transmission electron microscope (TEM). Mineralogical controls are also made from observations of thin sections and of coarse $(>63 \mu \mathrm{m})$ fractions separated on the same set of samples treated for clay extractions; "Tracor" microprobe investigations (energy dispersive X-ray analysis) were made on bulk fragments of samples or separated grains, and observed under a JEOL JSM840 scanning electron microscope (SEM). Quantitative XRD analysis is difficult and aleatory in such polyphased heterogeneous facies (Eberhart, 1989), and the relative abundances of minerals, with an average precision of about $10 \%$, were estimated from the height of the main refection and comparisons with preceding and following samples. Results are given in Tables 3 to 7.

\section{Geochemical Analyses}

Bulk chemical analyses were run on the same set of samplesbulk rocks or individual fragments. Prior to the elemental analysis, the samples were dried at $110^{\circ} \mathrm{C}$ and melted in a mixture of lithium tetraborate and introduced into a glycolated solvent. Major element analyses were performed following the method described by Besnus and Rouault (1973), using arc spectrometry and an ARL quantimeter. $\mathrm{Na}$ and $\mathrm{K}$ contents were determined by emission spectrometry. Major elements are expressed in percentage of oxides, the weight loss on ignition (LOI, at $1000^{\circ} \mathrm{C}$ ) in percentage, for $100 \mathrm{~g}$ of dried sample and with a relative precision of $\pm 2 \%$.
Trace elements were determined using an inductively coupled plasma technique (ICP-35000-ARL) (Samuel et al., 1985). The relative precision for minor elements (in parts per million, or $\mathrm{ppm}$ ) is $\pm 10 \%$. Results are given in Tables 8 to 11 .

\section{MINERALASSOCIATIONS: EXPRESSION OF THE ORIGIN AND EVOLUTION OF THE SEDIMENTARY SEQUENCE}

\section{Mineralogical Phases from the Alteration of the Upper Part of the Jurassic Crust}

The few samples analyzed as references for alteration products of basaltic basement are (Tables 2 and 4): (1) a calcareous silicified tuff and a radiolarian metasiltstone interbedded with basalt, (2) the yellow hydrothermal deposit with botryoidal structures and a thin millimetric, white layer at its base, (3) the clayey and siliceous material between pillows and within veins and a breccia zone, and (4) slightly altered basalt pillow and flow.

The mineral composition of slightly altered basalt is feldspar, pyroxene, and olivine. Clay minerals show very broad diffraction peaks. The green interpillow material comprises prevalent, very wellcrystallized lathy celadonite with automorphic calcite and goethite (SEM observations). Celadonite also occurs within altered pillow margins, associated with smectites. The formula of the green dioctahedral mica is $(\mathrm{Si}, \mathrm{Al})_{4} \mathrm{~K}(\mathrm{Mg}, \mathrm{Fe}, \mathrm{Al})_{2} \mathrm{O}_{10}(\mathrm{OH})_{2}$. Further microprobe analyses will provide more information on the chemistry of the Site 801 celadonite. Celadonite is a frequent secondary product of the low-temperature hydrothermal alteration of basalt (Alt et al., 1986). The yellow breccia zone between lava flows (igneous unit 23 from Shipboard Scientific Party, 1990b) is made of quartz, hematite, goethite, and calcite.

The remarkable hydrothermal ochre interval is quartz with goethite. The microscopic arrangement of the two phases is very imbricated, the goethite forms small $(10 \mu \mathrm{m})$ aggregates within joined quartz grains (Pl. 1, Fig. 1). The intergranular porosity is near zero. At the base of this massive hydrothermal deposit a small piece, $1.5 \mathrm{~cm}$ thick, has two thin layers: the lower laminae is white, the upper is pale yellow (Sample 129-801C-4R-1, 101-102 cm). XRD analysis establishes prevalent quartz and traces of a phosphatic phase. In SEM observation, the spectacular occurrence of apatite is revealed, more abundant in the white part of the sample: apatite forms $20-\mu \mathrm{m}$ crystals mixed with very small $(5-10 \mu \mathrm{m})$ automorphic bipyramidal quartz crystals (Pl. 1, Fig. 2). The apparent porosity of this small interval is greater than that of the massive ochre.

Hydrothermal authigenesis of apatite is rarely described. Similar automorphic quartz and texture was found within hydrothermal metalliferous deposits within upper lava sequences of the Oman ophiolite, and an occurrence of phosphate-enriched zones was also found in such lenses (Karpoff et al., 1988). In the present case the formation of apatite may have resulted from the fast interaction between lava, scarce biogenic phases, and hydrothermal fluids. The supply of phosphorous to oceanic deposits from ridge axes is evoked by Froelich et al. (1977) and Kolodny (1981). The temperature of formation of the ochre hydrothermal deposit is about $40^{\circ} \mathrm{C}$ (Alt et al., this volume).

The interbedded sedimentary lense analyzed within the upper part of the crustal sequence ( $41 \mathrm{~m}$ below the basement-sediment interface) is made of prevalent carbonates as ankerite $\left(\mathrm{Ca}(\mathrm{Fe}, \mathrm{Mg}, \mathrm{Mn})\left(\mathrm{CO}_{3}\right)_{2}\right)$ and calcite associated with quartz. Hydrothermal recrystallization of biogenic carbonate at low temperature (about $70^{\circ} \mathrm{C}$ ), forming dolomite, has been described in basal metalliferous sediments elsewhere (McKenzie et al., 1990, and references therein). Carbonates also form during low temperature, reducing alteration processes of oceanic basalts (Alt et al., 1986).

The various secondary minerals found in these few sites of the uppermost crustal sequence (celadonite, smectites, quartz, goethite, 
Table 1. Samples from Hole 800A and their main macroscopic characteristics.

\begin{tabular}{|c|c|c|}
\hline $\begin{array}{c}\text { Sample } \\
\text { (cm, top) }\end{array}$ & $\begin{array}{l}\text { Depth } \\
\text { (mbsf) }\end{array}$ & Unit \\
\hline \multicolumn{3}{|l|}{ 129-800A- } \\
\hline & & I-Pelagic brown clay-Tertiary to upper Campanian (0-38 mbsf) \\
\hline IR-CC, 1 & 0.28 & Relatively homogeneous dark brown (5YR $3 / 2-2.5 / 2)$ soft clay \\
\hline $3 \mathrm{R}-1,136$ & 11.96 & Relatively homogeneous dark brown ( 5 YR $3 / 2-2.5 / 2$ ) soft clay \\
\hline $4 \mathrm{R}-1,97$ & 21.27 & Relatively homogeneous dark brown $(5 Y \mathrm{R} 3 / 2-2.5 / 2)$ soft clay \\
\hline $4 \mathrm{R}-2,67$ & 22.37 & Relatively homogeneous dark brown (5YR $3 / 2-2.5 / 2$ ) soft clay \\
\hline $4 \mathrm{R}-2,116$ & 22.86 & Relatively homogeneous dark brown (5YR $3 / 2-2.5 / 2$ ) soft clay \\
\hline $4 \mathrm{R}-3,80$ & 24.00 & Relatively homogeneous dark brown (5YR $3 / 2-2.5 / 2$ ) soft clay \\
\hline $4 \mathrm{R}-4,17$ & 24.87 & Relatively homogeneous dark brown ( 5 YR $3 / 2-2.5 / 2$ ) soft clay \\
\hline & & II-Brown cherts and porcellanites - Campanian to Turonian (38-78.2 mbsf) \\
\hline $6 \mathrm{R}-1.7$ & 39.67 & Brown $(7.5$ YR $4 / 2)$ \\
\hline $6 \mathrm{R}-1,37$ Clear & 39.97 & Reddish yellow (7.5YR 6/6) \\
\hline 6R-1,38 Dark & 39.98 & Dark brown (7.5YR $3 / 2)$ \\
\hline $7 \mathrm{R}-1,66$ & 49.86 & Dark reddish brown $(5$ YR $3 / 3)$ \\
\hline $8 \mathrm{R}-1,1$ & 58.91 & Reddish brown and pink ( 5 YR $4 / 3$ and $8 / 4$ ) fine laminae \\
\hline $8 \mathrm{R}-1,22$ & 59.12 & Light reddish brown (5YR 6/4) \\
\hline $9 \mathrm{R}-1,1$ & 68.51 & Opalescent fragment (5YR 6/4) with small fissure \\
\hline & & III-Gray siliceous limestones and cherts-Albian to Cenomanian (78.2-228.6 mbsf) \\
\hline $10 \mathrm{R}-1,13$ & 78.33 & Gray (5Y 5/1), with small spots of pyrite \\
\hline $11 \mathrm{R}-1,90$ Clear & 88.70 & Very light gray $(5 Y 8 / 1-7 / 1)$ \\
\hline 11R-1, 91 Dark & 88.71 & Olive gray $(5 Y 5 / 2)$ \\
\hline $12 \mathrm{R}-1,37$ & 97.67 & Light olive gray $(5 Y 6 / 2)$ \\
\hline $13 \mathrm{R}-1,46$ & 107.26 & White $(5 Y 8 / 2)$ \\
\hline $14 \mathrm{R}-1,101$ & 117.21 & Light greenish gray $(5 Y 7 / 2)$ \\
\hline $17 \mathrm{R}-1,25$ & 144.45 & Light gray $(5 Y 7 / 1)$ \\
\hline $18 \mathrm{R}-1,70$ & 154.40 & Light gray $(2.5 Y 7 / 2)$ \\
\hline $18 \mathrm{R}-1,121$ & 154.91 & Light gray $(5 Y 7 / 1)$ \\
\hline $19 \mathrm{R}-1,1$ & 162.91 & Pale greenish gray \\
\hline $19 \mathrm{R}-1,37$ & 163.27 & Olive gray $(5 \mathrm{Y} 4 / 2)$, sandy \\
\hline 21R-1, 54 Gray & 181.84 & Light gray $(5 Y 7 / 1)$ \\
\hline 21R-1, 56 White & 181.86 & White $(5$ Y $8 / 2)$ \\
\hline $21 \mathrm{R}-2,8$ & 182.88 & White $(5 Y 8 / 1)$ \\
\hline $22 \mathrm{R}-1,19$ & 191.19 & Light gray (5Y $7 / 2)$; soft, clayey \\
\hline $24 \mathrm{R}-1,30$ & 210.20 & Pale brown $(10 \mathrm{YR} 6 / 3)$ \\
\hline & & IV - Redeposited volcaniclastic sandstones to claystones - Aptian (228.6-449.6 mbsf) \\
\hline $26 \mathrm{R}-1,4$ & 228.64 & Apple green, clayey, soft \\
\hline $26 \mathrm{R}-1,106$ & 229.66 & Green, silty \\
\hline $26 \mathrm{R}-2,12$ & 230.22 & Black $(5 Y 2.5 / 1)$, sandy \\
\hline $27 \mathrm{R}-1,30$ & 238.30 & Olive gray ( 5 Y $5 / 2$ ) \\
\hline $28 \mathrm{R}-1,82$ & 248.02 & Olive gray ( 5 Y $5 / 2)$ \\
\hline $28 \mathrm{R}-2,48$ & 249.18 & Gray $(5 Y 6 / 1)$ silty, thin laminae \\
\hline $28 \mathrm{R}-4,2$ & 251.72 & Grayish brown (2.5Y $5 / 2)$ clayey, thin laminae \\
\hline $29 \mathrm{R}-3,72$ & 260.22 & Light gray $(5 Y 6 / 2)$, thin laminae \\
\hline $30 \mathrm{R}-2,25$ & 267.65 & Light gray $(10 \mathrm{YR} 6 / 2)$, clayey \\
\hline $33 \mathrm{R}-2,146$ & 290.46 & Pale green, sandy \\
\hline $33 \mathrm{R}-7,63$ & 296.33 & Dark reddish gray (5YR $4 / 2$ ), clayey \\
\hline $35 \mathrm{R}-2,98$ & 308.88 & Light grayish green $(5 Y 7 / 1)$, clayey \\
\hline $36 \mathrm{R}-2,39$ & 317.79 & Dark brown $(7.5 Y R 3 / 2)$, clayey \\
\hline $36 \mathrm{R}-3,28$ & 319.18 & Greenish gray ( $5 Y$ Y $5 / 1$ ), clayey (with a sharp contact with sand) \\
\hline 37R-CC, 1 & 328.02 & Olive gray $(5 Y 5 / 2-5 / 3)$, sandy \\
\hline $38 \mathrm{R}-1,12$ & 334.62 & Greenish, clayey with an apple green lamina \\
\hline $38 \mathrm{R}-1,24$ & 334.74 & Reddish brown (5YR 5/4) with Mn dendrites \\
\hline 38R-1, 29 Nodule & 334.79 & Black manganese micronodule extracted from bulk deposit \\
\hline $39 \mathrm{R}-2,111$ & 337.15 & Olive gray $(5 \mathrm{Y} 4 / 2)$ \\
\hline $41 \mathrm{R}-1,93$ & 363.43 & Green, silty sand \\
\hline $50 \mathrm{R}-1,59$ & 440.79 & Brown, clayey \\
\hline \multicolumn{3}{|r|}{$\mathrm{V}$-Clayey radiolarites to siliceous claystones-Valanginian-Barremian (449.6-498.1 mbsf) } \\
\hline $51 \mathrm{R}-1,88$ & 450.48 & Red (2.5YR 5/6) with darker patches (10R 3/4) \\
\hline 51R-1, 135 Clear & 450.95 & Pinkish gray $(5 Y R 6 / 2)$, soft \\
\hline 5IR-1, 136 Dark & 450.96 & Dark reddish gray ( 5 YR $4 / 2)$, hard \\
\hline $52 \mathrm{R}-1,141$ & 460.21 & Pinkish gray $(7.5$ YR $6 / 2)$ with black laminae, silty \\
\hline $52 \mathrm{R}-2,86$ & 461.16 & Pinkish gray $(7.5 Y R 7 / 2)$ \\
\hline 52R-2, 86 Fissure & 461.20 & Thin white fissure with dark coatings extracted from bulk deposit \\
\hline $53 \mathrm{R}-1,117$ & 466.07 & Pinkish gray $(5 Y R 6 / 2$ ) with black coatings \\
\hline $53 \mathrm{R}-2,25$ Pink & 466.65 & Pinkish gray $(7.5$ YR $6 / 2)$ \\
\hline 53R-2, 27 Brown & 466.67 & Pinkish gray $(7.5 Y R 6 / 2)$ with abundant black patches \\
\hline $55 \mathrm{R}-1,126$ & 480.36 & Pinkish gray $(5 Y R 7 / 2)$ silty \\
\hline
\end{tabular}


Table 2. Samples from Site 801 and their main macroscopic characteristics.

\begin{tabular}{|c|c|c|c|c|}
\hline $\begin{array}{c}\text { Sample } \\
\text { (cm, top) }\end{array}$ & $\begin{array}{l}\text { Depth } \\
\text { (mbsf) }\end{array}$ & \multicolumn{3}{|c|}{ Unit } \\
\hline \multicolumn{5}{|l|}{ 129-801A- } \\
\hline & & \multicolumn{3}{|c|}{ I-Brown pelagic clay-Tertiary to Campanian (8-63.8 mbsf) } \\
\hline $1 \mathrm{R}-1,40$ & 8.40 & \multirow{2}{*}{ IA } & \multicolumn{2}{|c|}{ Homogeneous dark reddish brown ( 5 YR $2.5 / 2$ to 7.5 YR $3 / 4$ ) soft clay } \\
\hline $3 \mathrm{R}-1,63$ & 21.03 & & \multicolumn{2}{|c|}{ Homogeneous dark reddish brown (5YR $2.5 / 2$ to 7.5 YR $3 / 4$ ) soft clay } \\
\hline $3 R-2,145$ & 23.35 & \multicolumn{3}{|c|}{ Homogeneous dark reddish brown (5YR $2.5 / 2$ to 7.5 YR $3 / 4$ ) soft clay } \\
\hline $5 \mathrm{R}-1,13$ & 39.73 & \multicolumn{3}{|c|}{ Dark yellowish brown (10YR 3/4) clay } \\
\hline $5 R-1,15$ & 39.75 & \multicolumn{3}{|c|}{ Light yellowish brown (10YR 6/4) nannofossil ooze } \\
\hline $5 \mathrm{R}-1,62$ & 40.22 & \multicolumn{3}{|c|}{ Light yellowish brown (10YR 6/4) nannofossil ooze } \\
\hline $5 \mathrm{R}-1,63$ & 40.23 & \multicolumn{3}{|c|}{ IB Dark yellowish brown (10YR 3/4) clay } \\
\hline $7 \mathrm{R}-1,67$ & 59.67 & \multicolumn{3}{|c|}{ Dark brown to brown ( 7.5 YR $4 / 4$ to $5 / 6$ ) clay } \\
\hline & & \multicolumn{3}{|c|}{ II-Brown cherts and porcellanites-Campanian-Cenomanian (63.8-126.5 mbsf) } \\
\hline 7R-CC, 1 & 63.96 & \multicolumn{3}{|c|}{ Pinkish gray $(7.5 \mathrm{YR} 6 / 7)$ with pink laminae } \\
\hline 10R-1.11 & 87.61 & \multicolumn{3}{|c|}{ Light reddish brown (5YR 6/3) } \\
\hline & & \multicolumn{3}{|c|}{ III-Volcaniclastic turbidites and Pelagic intervals-Cenomanian-Albian (126.5-318.3 mbsf) } \\
\hline $16 \mathrm{R}-1,4$ & 145.64 & & Gray (5Y 5/1) clayey & \\
\hline $16 \mathrm{R}-1,140$ & 147.00 & & Dark gray (5Y 4/1) sandy & \\
\hline $19 \mathrm{R}-1,55$ & 175.25 & & Green, clayey & \\
\hline $19 \mathrm{R}-1,70$ & 175.35 & & Pale grayish green, clayey & \\
\hline \multicolumn{5}{|l|}{ 129-801B- } \\
\hline $2 \mathrm{R}-1,41$ & 203.91 & & Olive gray $(5 \mathrm{Y} 4 / 2)$, sandy & \\
\hline $3 R-1,100$ & 213.90 & & Gray (5Y 5/1), clayey & \\
\hline $5 \mathrm{R}-1,50$ Green & 232.20 & & Light olive gray ( 5 Y $6 / 2)$ & Sandy, thin laminae with \\
\hline $5 \mathrm{R}-1,52$ Brown & 232.22 & & Grayish brown $(2.5$ Y $5 / 2)$ & $\int_{\text {gradational color change }}$ \\
\hline $5 R-2,84$ & 234.04 & & Green & \\
\hline $6 \mathrm{R}-4,62$ & 246.42 & & Pale green, clayey & \\
\hline $7 R-1,34$ & 251.34 & & Pale green, clayey & \\
\hline $8 \mathrm{R}-1,130$ & 262.00 & & Gray $(5 Y 5 / 1)$, clayey & \\
\hline $8 R-5,102$ & 267.72 & & Light olive gray $(5 Y 6 / 2)$, clayey & \\
\hline & & IV- & -Brown radiolarites-Valanginian-Oxfordian (318.3-44 & $9 \mathrm{mbsf})$ \\
\hline 14R-1, 24 Gray & 318.54 & IVA & Pinkish gray $(7.5 Y R 7 / 2)$, hard & \\
\hline 14R-1, 25 Pink & 318.55 & & Pink, with black small patches & \\
\hline $18 \mathrm{R}-1,24$ & 356.04 & & Very pale brown (10YR $7 / 3)$ with $\mathrm{Mn}$ & \\
\hline $24 \mathrm{R}-1,54$ & 401.14 & IVE & 3 Light brownish gray $(10 Y R$ R/2) with Mn micronodule & \\
\hline $25 \mathrm{R}-1,1$ & 405.21 & & Pinkish gray (7.5YR 7/2) with Mn patches & \\
\hline 27R-1, 30 & 415.00 & & Chert, reddish brown and weak red ( 2.5 YR 5/4-5/2) & \\
\hline & & $\mathrm{V}-$ & -Radiolarites and claystones - Callovian-Bathonian (442 & $9-461.6 \mathrm{mbsf})$ \\
\hline $33 \mathrm{R}-1,43$ & 443.23 & & Strong brown ( 7.5 YR $5 / 6)$ & \\
\hline $33 \mathrm{R}-2,48$ & 444.78 & & Yellowish red (5YR 5/8) soft & \\
\hline $35 \mathrm{R}-2,120$ & 455.00 & & Dark red (2.5YR 3/6) & \\
\hline $35 \mathrm{R}-2,140$ & 455.20 & & Dark red (2.5YR 3/6) with yellowish patches & \\
\hline 35R-3, 1 Red & 455.31 & & Dark red (2.5YR 3/6), soft, on external zone & Separated areas of \\
\hline 35R-3, 3 Yellow & 455.33 & & Strong brown (7.5YR 5/6), hard, as a nodular zone & $\int_{\text {the same sample }}$ \\
\hline $35 \mathrm{R}-3,19$ & 455.49 & & Dark red $(2.5 Y R 3 / 6)$ & \\
\hline & & VI- & -Interbedded basalt and silicified claystone-Callovian- & 3athonian \\
\hline 44R-1, 125 Brown & 502.95 & & Reddish gray $(5 Y R 5 / 2)$ & Fragments from \\
\hline $44 \mathrm{R}-1,126$ Green & 502.96 & & Light olive gray $(5 Y 6 / 2)$ & $\int_{\text {the same interval }}$ \\
\hline $44 \mathrm{R}-1,132$ & 503.03 & & Light reddish brown ( 5 YR $6 / 4)$ and darker patches & \\
\hline 129-801C- & & & & \\
\hline & & $\mathrm{Hyc}$ & Irothermal ochre & \\
\hline $4 \mathrm{R}-1,73$ & 522.43 & & Light yellowish brown to olive yellow $(2.5 Y$ Y $6 / 4,6-6$ ) & \\
\hline $4 \mathrm{R}-2,101$ & 524.08 & & Yellow $(2.5 Y 7 / 6)$ & Two very thin layers \\
\hline 4R-2, 102 White & 524.09 & & White $(2.5$ Y $8 / 2)$ & \\
\hline & & Inte & rpillow deposits and alteration products & \\
\hline SR-2, 99 Green & 533.45 & & Grass green fissure from grayish gray basalt & \\
\hline 5R-5, 124 Green & 537.93 & & Grass green fragment & \\
\hline $7 \mathrm{R}-3,120$ & 554.18 & & Brownish yellow (10YR 6/8), alteration product & \\
\hline $8 \mathrm{R}-1,23$ & 559.73 & & Dark reddish brown (5YR $2.5 / 2$ ), with few green fragm & nts, margin of altered pillow \\
\hline 9R-2, 97 & 565.57 & & Basalt & \\
\hline
\end{tabular}

apatite, ankerite, and calcite) are those of low-temperature parageneses resulting from the interactions between basalt, low sedimentary supply, and hydrothermal fluids. The fluid circulation is also demonstrated by the textural features of the silicified facies and of the fracture network (see figures in Lancelot, Larson, et al., 1990). Redox conditions appear at the border between oxidizing and reducing environments, which exist in the affected micro-sites (interpillow, sedimentary lenses).

\section{Jurassic Basal Radiolarite and Claystone (Stage 1)}

Callovian-Bathonian red radiolarite and claystone at Site 801 (Unit V) comprise quartz, dioctahedral smectite $(d\{060\}$ between 1.48 and $1.50 \AA$ ), hematite, and some goethite. Volcanogenic minerals (mainly feldspars) are ubiquitous. In place, barite occurs in trace amounts. Barite is a common constituent of pelagic siliceous oozes 
and cherts, where the mineral is often related to early biomineralization processes (Goldberg and Arrhenius, 1958; Church, 1979). A hydrothermal origin is also suggested for deposits near spreading axes (Arrhenius and Bonatti, 1965; Church, 1979; McMurtry and Yeh, 1981). It is often difficult to discriminate between both origins in siliceous deposits formed near volcanic edifices or ridge axes (Karpoff, 1980; Karpoff et al., 1988). The preservation of barium within these deposits during the early diagenetic dissolution-recrystallization of biogenic compounds seems favored in such "active" environments.

The proportion of quartz is negatively correlated with that of smectites and oxides. The upper part of the unit (Core 129-801B-33R) appears richer in quartz and feldspar than the lower part close to the basement (Core 129-801B-35R) where goethite occurs associated with hematite. The frequent fine white fillings of the fissures crosscutting the laminations are made of cryptocrystalline quartz enclosing radiolarian tests, spheric aggregates of iron oxides, and thin manganese coatings (SEM observation). These fracture fillings are broken as small slabs within the coarse fraction of the deposit which contains an abundant radiolarian fauna. The tests are often recrystallized, with microcrystalline quartz or chalcedony infillings.

The fine fraction $(<2 \mu \mathrm{m})$ is made of prevalent well-crystallized smectites with a rare $10 \AA$ phase as illite, interlayered illite-smectite (I-S), goethite, and still-present quartz. Goethite and interlayered I-S are more abundant in the lower part; illite is better represented in the more quartzitic samples (Table 5). Smectites are mainly dioctahedral (large reflection between 1.50 and $1.51 \AA$ ). Under TEM (PI. 1, Fig. 3), hematite displays clusters of very small rice-shaped grains $(0.1-$ $0.2 \mu \mathrm{m}$ ), and the particles of smectite exhibit a flaky feature with diffuse borders which is common for authigenic and diagenetic smectites.

The Callovian-Bathonian radiolarite and siliceous claystone are comparable, by their composition and textural features, to basal metalliferous sediments recovered either along ridges axes, or in a similar stratigraphic position overlying ophiolite sequences, and whose formation is related to the interaction between biogenic and hydrothermal phases (Bonatti et al., 1972; McMurtry and Yeh, 1981; Bonatti, 1981; Cole, 1985; Karpoff et al., 1988).

\section{Oxfordian to Barremian Biosiliceous Sediments (Stage 2)}

Clayey radiolarite, siliceous claystone, and brown radiolarite deposited during the Late Jurassic and Early Cretaceous (Site 801Unit IV, and Site 800 - Unit V) contain prevalent quartz with smectite (Tables 3 and 4). The dissimilarity between coeval sediments is mainly the occurrence of abundant opal-CT (main peak at $4.05 \AA$ ) in the Valanginian section at Site 801 (Core 129-801B-14R). The silica phases consistently decrease upward at both sites. The accessory minerals also emphasize small differences and heterogeneities: iron oxides and trace amounts of zeolites occur at Site 800, and illite and halite are present at the Jurassic-Cretaceous transition (Cores 129801B-18R and -24R).

The numerous black patches and micronodules of manganese oxides are not in evidence on the bulk XRD diagrams. Nevertheless, within the pinkish gray Valanginian radiolarite (Site 801), crystallites of manganese oxide are easily identified on the borders of the opaline tests of radiolarians (PI. 1, Fig. 4). The well-crystallized manganese occurs as rods, up to $40 \mu \mathrm{m}$ long, closely mixed with very thin, curly fibers of smectite.

The fine fraction of these deposits (Table 5) is composed of dioctahedral smectite $(d\{060\}=1.50 \AA)$, illite, and interlayered I-S phases; clay-sized quartz is present as well. Palygorskite fibers are also observed under TEM, associated with flaky particles of smectite, large illite particles with hairy outlines resulting from poor preservation, and small spherules of opal.

This mineral association corresponds to the early diagenetic evolution of the biosiliceous sediment (formation of smectite, scarce palygorskite, manganese oxide, and, in place of phillipsite, recrystallization of biogenic silica) which also contains primary detrital clays.

\section{Volcaniclastic Turbidites from the Middle Cretaceous Event (Stage 3)}

The middle Cretaceous redeposited volcaniclastic sand-, silt-, and claystones overshadow the biosiliceous background sedimentation (Site 800-Unit IV; Site 801-Unit III). These deposits display various secondary diagenetic minerals resulting from intense interactions between interstitial water and primary biogenic and volcanogenic phases (France-Lanord et al., this volume). Several distinct mineral associations including ubiquitous volcanogenic feldspar, pyroxene, and olivine have been defined and appear stratigraphically in ascending order; they may be time dependent (Tables 3 and 4). These associations, from bottom to top and with minerals in decreasing order of abundance, are (for Site 800):

a. Smectites, with trace amounts of quartz, phillipsite, clinoptilolite, and well-crystallized manganite;

b. Smectites, calcite, phillipsite, and traces of quartz with clinoptilolite;

c. Opal-CT, quartz, smectites, and traces of clinoptilolite;

d. Smectites and celadonite (negatively correlated in abundance), clinoptilolite, quartz, and sometimes smectites alone.

The associations (for Site 801) are:

e. Smectites and celadonite (negatively correlated in abundance), clinoptilolite, quartz, and sometimes smectites alone;

f. Smectites, analcime, and phillipsite; and

g. Opal-CT, clinoptilolite, smectites, and trace amounts of celadonite.

From this set of data, clinoptilolite occurs in silica-rich intervals which are also pale brown to gray-colored, whereas rarer phillipsite is associated with calcite. This discrimination is well established; the zeolite with the highest $\mathrm{Si} / \mathrm{Al}$ ratio forms within silica-rich deposits (Kastner, 1979, 1981, and references therein). During basalt-seawater interactions, the formation of zeolite is favored when another nonbasaltic source of silica, such as biogenic silica, is added (Crovisier et al., 1987). Local peculiarities include a high analcime content within a dark olive siltstone (Sample 129-801B-2R-1, 41-46 cm), opal-CT-rich layers (reflection at $4.06 \AA$ ) at both sites, and very well-crystallized manganite as nodules or laminae at the base of the sequence from Site 800 . Analcime reflects a greater contribution of basaltic phases at possibly slightly higher temperature than the clinoptilolite most frequently found in diagenetically altered biogenic sediments. The manganite, $\mathrm{MnOOH}$, forms small coalescent platelets (Pl. 2, Fig. 1). This hydroxide is not commonly described in recent sediments. At Site 800, manganite could have resulted from aging of primarily less-ordered phases such as birnessite formed during early oxidizing diagenesis.

A frequently observed morphology of smectites is that of honeycomb nontronite found within altered hyaloclastites and bentonites (Khoury and Eberl, 1979; Karpoff et al., 1980; Konta, 1986). Nevertheless, within the volcaniclastics from Sites 800 and 801 , supple fibers and fibrilla, slightly curled, making "bridges" between aggregates (Pl. 2, Figs. 2 and 3), are more common. This feature is similar to that of the hydrothermal clay from the Galapagos hydrothermal mounds (Kurnosov et al., 1983; Karpoff, 1989) and that of fibrous illite formed by burial diagenesis (Keller et al., 1986). Calcite is a recrystallized phase mixed with clay minerals in fine fractures. Radiolarians trapped within the volcanogenic material are poorly preserved and the tests are often completely clay-replaced and quartz-filled; the clinoptilolite of such a clayey interval displays very small crystallites (Pl. 2, Fig. 4).

Clay minerals are smectites and celadonite (dioctahedral mica). From the double $d\{060\}$ peak on XRD diagrams (1.50 and $1.53 \AA$ ), trioctahedral clay minerals appear associated with dioctahedral clay minerals. The clay from the analcime-rich interval is predominantly a trioctahedral smectite. The fine fraction extracted from some inter- 
Table 3. Bulk mineralogical composition of the sediments from Site 800, estimated by X-ray diffraction on powdered samples.

\begin{tabular}{|c|c|c|c|c|c|c|c|c|c|c|c|}
\hline $\begin{array}{c}\text { Sample } \\
\text { (cm, top) }\end{array}$ & $\begin{array}{l}\text { Depth } \\
\text { (mbsf) }\end{array}$ & Quartz & Opal-CT & Calcite & Phillipsite & Clinoptilolite & Smectite & $10 \AA^{a}$ & Halite & Fe-oxides & $\begin{array}{l}\text { Volc. } \\
\text { minerals }\end{array}$ \\
\hline \multicolumn{12}{|l|}{$129-800 \mathrm{~A}-$} \\
\hline 1R-CC, 1 & 0.28 & $x x$ & & & $\mathrm{xx}$ & o & $\mathrm{xxx}$ & o & $\mathrm{x}$ & & o \\
\hline $3 \mathrm{R}-1,136$ & 11.96 & $x x$ & & & $\mathrm{xx}$ & o & $\mathrm{xx}$ & o & $\mathrm{x}$ & & o \\
\hline $4 \mathrm{R}-1,97$ & 21.27 & $\mathrm{x}$ & & & $\mathrm{xx}$ & o & $\mathrm{xx}$ & o & o & o & o \\
\hline $4 R-2,67$ & 22.37 & $x$ & & & $\mathrm{xx}$ & $\mathrm{x}$ & $\mathrm{xx}$ & o & o & o & o \\
\hline $4 \mathrm{R}-2,116$ & 22.86 & $\mathrm{x}$ & & & $x$ & $x x$ & $\mathrm{xx}$ & 0 & 0 & o & o \\
\hline $4 \mathrm{R}-3,80$ & 24.00 & $x$ & & & $\mathrm{x}$ & $\mathrm{xx}$ & $x x x$ & o & & & o \\
\hline $4 \mathrm{R}-4,17$ & 24.87 & $x$ & & & $x$ & $\mathrm{xx}$ & $\mathrm{xx}$ & & & & o \\
\hline $6 \mathrm{R}-1,7$ & 39.67 & $\mathrm{xx}$ & $\mathrm{xxxx}$ & & o & & o & & & & \\
\hline 6R-1, 37 Clear & 39.97 & $x$ & $x x x$ & & - & $x$ & $\mathrm{x}$ & & & & \\
\hline 6R-1, 37 Dark & 39.98 & $x$ & $\operatorname{xxxxx}$ & & & o & 0 & & & & \\
\hline $7 \mathrm{R}-1,66$ & 49.86 & $x \mathbf{x}$ & $\mathrm{xxx}$ & & & - & & & & & \\
\hline $8 \mathrm{R}-1,1$ & 58.91 & $\mathrm{x}$ & $\operatorname{xxxxx}$ & & & - & - & & & & o \\
\hline $8 \mathrm{R}-1,22$ & 59.12 & o & $\operatorname{xxxxx}$ & & & o & o & & & & o \\
\hline $9 \mathrm{R}-1,1$ & 68.51 & $\operatorname{xxxxxx}$ & o & & & & & & & & \\
\hline $10 \mathrm{R}-1,13$ & 78.33 & $x x$ & $x x x x$ & & - & & & & & & \\
\hline 11R-1, 90 Clear & 88.70 & $x$ & $\mathrm{xx}$ & $\mathrm{xxx}$ & & & o & & & & \\
\hline 11R-1, 90 Dark & 88.71 & $\mathrm{xxxx}$ & $\mathrm{x}$ & $x$ & & & & & & & \\
\hline $12 \mathrm{R}-1,37$ & 97.67 & $\mathrm{xx}$ & $x x x$ & o & & & 0 & & & & \\
\hline $13 \mathrm{R}-1,46$ & 107.26 & $x$ & $\mathrm{x}$ & $x x x$ & & & & & & & \\
\hline $14 \mathrm{R}-1,101$ & 117.21 & $x x x$ & $x x x$ & - & & & o & o & & & \\
\hline $17 \mathrm{R}-1,25$ & 144.45 & $\mathrm{x}$ & $x x$ & $\mathrm{xxx}$ & & & & & & & \\
\hline $18 \mathrm{R}-1,70$ & 154.40 & $\mathrm{xx}$ & $\mathrm{xxx}$ & - & & & $\mathrm{x}$ & o & & & \\
\hline $18 \mathrm{R}-1,121$ & 154.91 & $\operatorname{xxxx}$ & $\mathrm{xx}$ & & & & o & & & & o \\
\hline $19 \mathrm{R}-1,1$ & 162.91 & $\mathrm{xx}$ & $\mathrm{xxx}$ & o & & & $\mathrm{x}$ & oP & & & 0 \\
\hline $19 \mathrm{R}-1,37$ & 163.27 & $\mathrm{xx}$ & $\mathrm{xx}$ & & & & $\mathrm{xx}$ & oP & & o & o \\
\hline $21 \mathrm{R}-1,54$ Gray & 181.84 & $\mathrm{xx}$ & $\mathrm{x}$ & & & 0 & $x x x$ & & & & o \\
\hline 21R-1, 54 White & 181.86 & $x$ & $x x$ & $x x x$ & & & o & & & & \\
\hline $21 \mathrm{R}-2,8$ & 182.88 & $\mathrm{x}$ & $\mathrm{x}$ & $\mathrm{xxxx}$ & & & & & & & \\
\hline $22 \mathrm{R}-1,19$ & 191.19 & $x$ & & $\mathrm{xx}$ & & $\mathrm{x}$ & $x x$ & o & & & o \\
\hline $24 \mathrm{R}-1,30$ & 210.20 & $\mathrm{xx}$ & $\operatorname{xxxx}$ & & & & o & o & & & \\
\hline $26 \mathrm{R}-1,4$ & 228.64 & $\mathrm{x}$ & & & & $x x$ & $x$ & $x \times C$ & & & \\
\hline $26 \mathrm{R}-1,106$ & 229.66 & - & & & & $\mathrm{xxx}$ & $\mathrm{xx}$ & $\mathrm{xxC}$ & & & $\Delta$ \\
\hline $26 \mathrm{R}-2,12$ & 230.22 & & & & & & $\operatorname{xxxx}$ & & & & $\Delta \Delta \Delta$ \\
\hline $27 \mathrm{R}-1,30$ & 238.30 & o & & & & $x x$ & $x x x$ & & & & $\Delta \Delta \Delta$ \\
\hline $28 \mathrm{R}-1,82$ & 248.02 & o & & & & & $\operatorname{xxxx}$ & $x \mathrm{C}$ & & & $\Delta \Delta$ \\
\hline $28 \mathrm{R}-2,48$ & 249.18 & $\mathrm{xx}$ & & & & $x x x$ & $\mathrm{xx}$ & & & & \\
\hline $28 \mathrm{R}-4,2$ & 251.72 & o & & o & & $\mathrm{x}$ & $\mathrm{xxx}$ & & & & $\Delta \Delta \Delta \Delta$ \\
\hline $29 \mathrm{R}-3,72$ & 260.22 & $x x$ & $\mathrm{xxx}$ & & & & $x$ & & & & \\
\hline $30 \mathrm{R}-2,25$ & 267.65 & $\mathrm{xx}$ & $\mathrm{xx}$ & & & $\mathrm{x}$ & $x x$ & & & & \\
\hline $33 \mathrm{R}-2,146$ & 290.46 & & o & $\mathrm{xxx}$ & 0 & & $\mathrm{xxx}$ & & & & $x$ \\
\hline $33 R-7,63$ & 296.33 & & & $x x$ & o & & $\mathrm{xxxx}$ & & & & $x$ \\
\hline $35 R-2,98$ & 308.88 & $\mathrm{x}$ & & & o & o & $\operatorname{xxxx}$ & & & & o \\
\hline $36 \mathrm{R}-2,39$ & 317.79 & o & & $\mathrm{xxx}$ & o & & $\mathrm{xxx}$ & & & & $x$ \\
\hline $36 \mathrm{R}-3,28$ & 319.18 & & & & & & $\operatorname{xxxxx}$ & oC & & & 0 \\
\hline 37R-CC, 1 & 328.02 & & & & & & $\operatorname{xxxx}$ & & & & $\Delta \Delta \Delta$ \\
\hline $38 \mathrm{R}-1,12$ & 334.62 & & & & o & & $x x x x$ & o C & & & $\Delta$ \\
\hline $38 \mathrm{R}-1,24$ & 334.74 & $\mathrm{x}$ & o & & & $\mathrm{x}$ & $x x x$ & & & & o \\
\hline $38 \mathrm{R}-1,29$ Nodule & 334.79 & & & & & & & & & & \\
\hline $39 \mathrm{R}-2,111$ & 337.15 & o & & & & & $x x x x x$ & oC & & & o \\
\hline $41 \mathrm{R}-1,93$ & 363.43 & & & 0 & o & & $x x x x$ & & & & $\Delta$ \\
\hline $50 \mathrm{R}-1,59$ & 440.79 & $\mathrm{x}$ & & & & & $x x x$ & & & & $\Delta \Delta \Delta$ \\
\hline 51R-1, 88 & 450.48 & $\mathrm{xxxx}$ & & & - & & $x x$ & & & o & \\
\hline 51R-1, 135 Clear & 450.95 & $x x x x$ & & & & & $\mathrm{xx}$ & & & & \\
\hline 5IR-1, 135 Dark & 450.96 & $x x x x$ & & & & & $\mathrm{x}$ & & & $\mathrm{x}$ & \\
\hline $52 \mathrm{R}-1,141$ & 460.21 & $\operatorname{xxxx}$ & & & & & $x x$ & & & o & \\
\hline $52 \mathrm{R}-2,86$ & 461.16 & $x x x$ & & & o & & $\mathrm{xx}$ & & & $\mathrm{x}$ & \\
\hline $52 \mathrm{R}-2,86$ Fissure & 461.20 & $\operatorname{xxxxxx}$ & & & & & & & & & \\
\hline $53 \mathrm{R}-1,117$ & 466.07 & $\operatorname{xxxxx}$ & & & & & $\mathrm{x}$ & & & & \\
\hline 53R-2, 25 Pink & 466.65 & $x \times x x x$ & & & & & $x$ & & & & \\
\hline 53R-2, 25 Brown & 466.67 & $x x x x$ & & & & & $\mathrm{x}$ & & & $\mathrm{x}$ & \\
\hline $55 \mathrm{R}-1,126$ & 480.36 & $x x x x x$ & & & & & $\mathrm{x}$ & & & o & \\
\hline
\end{tabular}

Notes: $-=$ traces; $o=$ present $x=$ relative abundance; $\Delta=$ mixture of volcanic minerals (with feldspars, pyroxenes, and olivine).

${ }^{a} 10 \AA=$ clay minerals at $10 \AA$ as illite; $\mathrm{P}=$ palygorskite; $\mathrm{C}=$ celadonite.

${ }^{b}$ Volcanodetrital minerals, mainly feldspars.

${ }^{\mathrm{c}}$ See text for full discussion. 
Table 3 (continued).

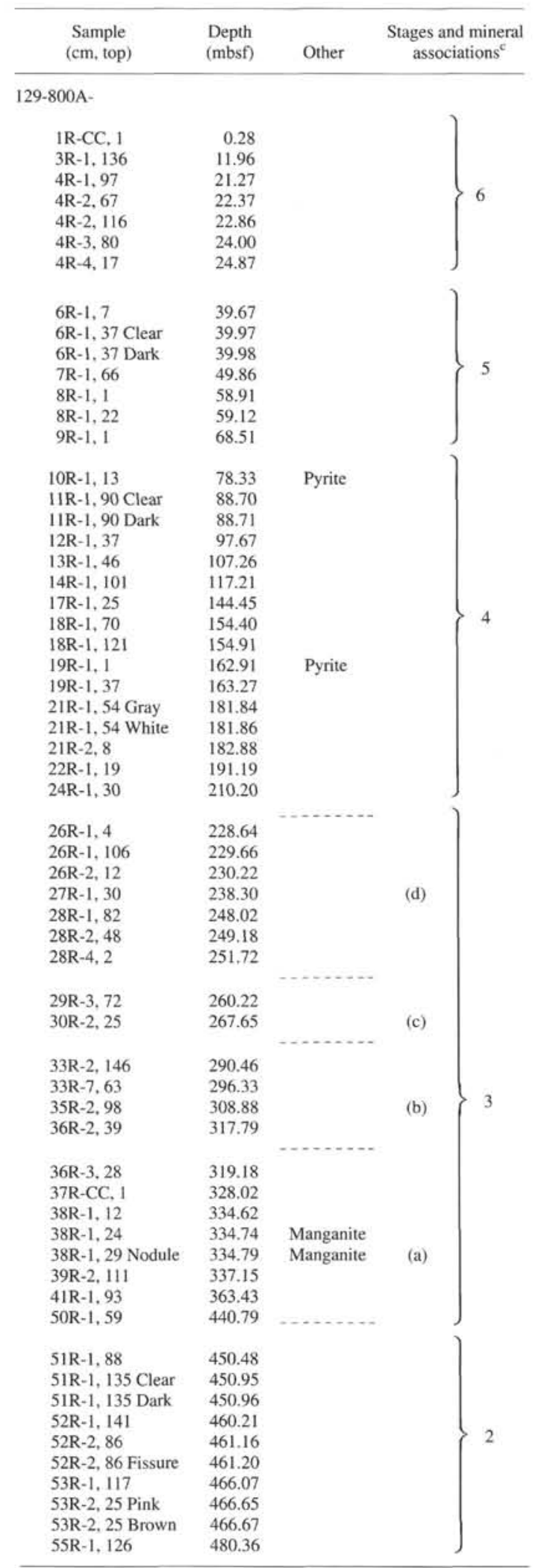

vals of the volcaniclastic sequences is composed of dominant smectites, celadonite, traces of interlayered I-S phases, and a possible $7-\AA$ phase such as kaolinite or halloysite (Table 6). Under TEM, clay particles exhibit various morphologies and some clay-sized zeolite fragments occur (Pl. 3, Figs. 1-3). Within the basal interval from Site 800 (mineral association "a"), the smectites display two types of particles: (1) large flakes with curled edges, and (2) thin, small laths forming a light felt. Within some samples, the rare squat cylinders can be identified as halloysite. Celadonite, which is more abundant at the top of the Site 800 sequence and the base of the Site 801 volcaniclastic sequence, exhibits very light platy particles. These mixed morphological types are found in the green clays from the Galapagos mounds (Honnorez et al., 1983; Buatier et al., 1989). In oceanic volcanogenic rocks, celadonite is formed at higher temperature $\left(>25^{\circ} \mathrm{C}\right)$ than iron-smectite (Bohkle et al., 1984; Duplay et al., 1989).

Peculiar and sometimes unusual mineral occurrences (calcite, analcime, and halloysite) illustrate the complexity of the diagenetic reactions within these heterogeneous deposits (France-Lanord et al., this volume). Part of the water-rock interaction could have occurred at higher temperatures than that of bottom seawater. Diagenetic paragenesis is not primarily controlled by the grain size of the deposit; clay-, silt-, and sandstones from the same turbidite bed do not show drastic differences. The variability of the paragenesis seems more related to the primary composition of the turbidite deposits, which varied stratigraphically.

The comparison between the two units (IV at Site 800 and III at Site 801) allows the mineral associations to be correlated (Tables 3 and 4). In consequence, a "mineral stratigraphy" is established within these thick, redeposited sediments from the successive mineral associations given above. The top of the upper Aptian unit at Site 800 (association "d") appears to be the lithologic equivalent of the base of the middle Albian section from Site 801 (association "e"). Petrographical features corroborate this correspondence; at both sites the turbidite facies, with fine-laminated thin beds, is similar. The correspondence is also recorded by the biogenic input characterized by the appearance of the radiolarian-nannofossil assemblage (Erba, this volume). This interval $(\mathrm{e}-\mathrm{d})$ is bounded at top and bottom by silica-rich intervals (c, g), reflecting the dominantly siliceous background biosedimentation.

The paleolatitude of Site 800 from late Aptian was the same as that of Site 801 during the middle Albian $\left(10^{\circ} \mathrm{S}\right.$, Fig. 3). Both sites appear to have been at the same distance from a distal fixed volcanic source (hotspot) at those times. Site 800 moved off from this source faster than Site 801 , back to a more subequatorial position in the high productivity belt, allowing biogenic sedimentation to dominate its sequence.

\section{Pelagic Sediments from Albian-Cenomanian Times (Stage 4)}

This stage in the sedimentary evolution of the Pigafetta Basin is represented only by lithological Unit III at Site 800 , consisting of limestone and gray chert. The mineralogical composition of the facies is in accordance with its macroscopic features, and contains mainly silica phases, opal-CT (reflection at 4.05 to $4.10 \AA$, increasing upward), and quartz of inversely varying proportions (Table 3 ). In places calcite is the prevalent mineral. Clay minerals are better represented within siliceous intervals, particularly at the base of the unit where clinoptilolite also occurs (Core 129-800A-24R to-18R). At this level the volcanogenic minerals, feldspar, and pyroxene are still present. Clay minerals are dioctahedral smectite $(d\{060\}$ at $1.50 \AA)$ and rare palygorskite. Accessory minerals are pyrite (around radiolarian tests) and oxides. The fine fraction comprises smectite, palygorskite, and rare illite and interlayered I-S phases (Table 5). The light particles of smectite have lath-shaped edges, with curled overgrowths. Palygorskite is long, lath-shaped. Aggregates of small granules of silica are very abundant (Pl. 4, Fig. 1). 
Table 4. Bulk mineralogical composition of the sediments and basement alteration products from Site 801, estimated by X-ray diffraction on powdered samples.

\begin{tabular}{|c|c|c|c|c|c|c|c|c|c|c|c|}
\hline $\begin{array}{c}\text { Sample } \\
(\mathrm{cm}, \text { top) }\end{array}$ & $\begin{array}{l}\text { Depth } \\
\text { (mbsf) }\end{array}$ & Quartz & Opal-CT & Calcite & Phillipsite & Clinoptilolite & Smectite & $10 \AA^{a}$ & Halite & Fe-oxides & $\begin{array}{l}\text { Volc. } \\
\text { minerals }\end{array}$ \\
\hline \multicolumn{12}{|l|}{ 129-801A- } \\
\hline IR-1, 40 & 8.40 & $x x$ & & & $x x$ & & $x x$ & $x$ & 0 & & o \\
\hline $3 R-1,63$ & 21.03 & $x$ & & & $x x$ & & $\mathrm{xx}$ & $x$ & 0 & & $x$ \\
\hline $3 R-2,145$ & 23.35 & $\mathrm{x}$ & & & $\mathrm{x}$ & & $x x x$ & $x$ & $\circ$ & & 0 \\
\hline $5 R-1,13$ & 39.73 & $x$ & & o & o & & $x x x$ & $x$ & $\mathrm{x}$ & & $\mathrm{x}$ \\
\hline $5 R-1.15$ & 39.75 & o & & $\operatorname{xxxx}$ & & & $\mathrm{x}$ & & & & \\
\hline $5 \mathrm{R}-1,62$ & 40.22 & o & & $\operatorname{xxxxx}$ & & & o & & & & \\
\hline $5 R-1,63$ & 40.23 & $x$ & & o & o & $\mathrm{x}$ & $\mathrm{xx}$ & $\mathrm{x}$ & $x$ & & $\mathrm{x}$ \\
\hline $7 \mathrm{R}-1,67$ & 59.67 & $\mathrm{x}$ & & & - & $\mathrm{xxx}$ & $\mathrm{xxx}$ & o & o & & $x$ \\
\hline 7R-CC. 1 & 63.96 & $x$ & $\mathrm{xxxx}$ & & & & o & & & & \\
\hline $10 \mathrm{R}-1,11$ & 87.61 & $x$ & $x x x x$ & & & & o & & & & \\
\hline $16 \mathrm{R}-1,4$ & 145.64 & o & & & & $x x x$ & $\mathrm{xx}$ & o C & & & o \\
\hline $16 \mathrm{R}-1,140$ & 147.00 & & & - & & & $\operatorname{xxxxx}$ & & & & $\Delta$ \\
\hline $19 \mathrm{R}-1,55$ & 175.25 & & $x$ & $\mathrm{x}$ & & $\mathrm{xx}$ & $\mathrm{xx}$ & $x \mathrm{C}$ & & & $\Delta$ \\
\hline $19 \mathrm{R}-1,70$ & 175.35 & o & $\operatorname{xxxx}$ & o & & $\mathrm{x}$ & $\mathrm{x}$ & & & & 0 \\
\hline
\end{tabular}

129-801B-

\begin{tabular}{|c|c|}
\hline $2 \mathrm{R}-1,41$ & 203.91 \\
\hline $3 R-1,100$ & 213.90 \\
\hline $5 R-1,50$ Green & 232.20 \\
\hline $5 R-1,50$ Brown & 232.22 \\
\hline $5 R-2,84$ & 234.04 \\
\hline $6 \mathrm{R}-4,62$ & 246.42 \\
\hline $7 R-1,34$ & 251.34 \\
\hline $8 R-1,130$ & 262.00 \\
\hline $8 R-5,102$ & 267.72 \\
\hline 14R-1, 24 Gray & 318.54 \\
\hline 14R-1, 24 Pink & 318.55 \\
\hline $18 \mathrm{R}-1,24$ & 356.04 \\
\hline $24 \mathrm{R}-1,54$ & 401.14 \\
\hline $25 \mathrm{R}-1,1$ & 405.21 \\
\hline $27 \mathrm{R}-1,30$ & 415.00 \\
\hline $33 \mathrm{R}-1,43$ & 443.23 \\
\hline $33 R-1,143$ & 444.23 \\
\hline $33 R-2,48$ & 444.78 \\
\hline $35 \mathrm{R}-2,120$ & 455.00 \\
\hline $35 \mathrm{R}-2,140$ & 455.20 \\
\hline 35R-3, 1 Red & 455.31 \\
\hline 35R-3, 1 Yellow & 455.33 \\
\hline $35 \mathrm{R}-3,19$ & 455.49 \\
\hline 44R-1, 125 Brown & 502.95 \\
\hline 44R-1, 125 Green & 502.96 \\
\hline $44 \mathrm{R}-1.132$ & 503.03 \\
\hline
\end{tabular}

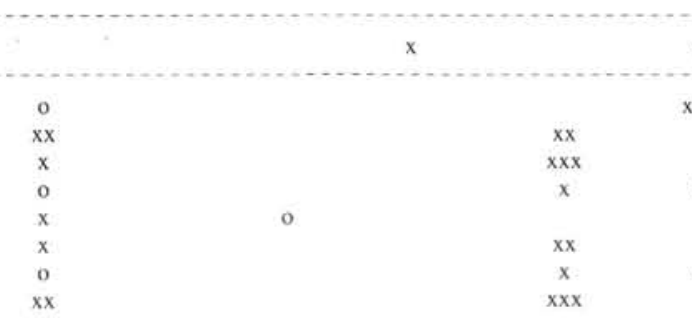

$\mathrm{xxx}$

$x x x x$
$x x$
$x x$
$x x x$
$x x$
$x$
$x x x$
$x$

o C

$x \mathrm{C}$

$x x \mathrm{C}$

$\operatorname{xxxC}$

$\begin{array}{ll}x x & x x x \\ x x & x x x\end{array}$

$\mathrm{xx}$
$\mathrm{xxxx}$

$x x x x$
$x x x x$

$\mathrm{xxxx}$

$x x x x x$

\section{$\operatorname{xxxx}$}

$\operatorname{xxxx}$

$\operatorname{xxxx}$

$x$
$x x$

$\mathrm{xx}$

$\mathrm{xx}$

$\mathrm{xx}$

$\mathrm{xx}$

$\underset{\operatorname{xxxx}}{-}$

\section{$x x x$}

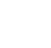

29-80IC-

4R-1, 73
4R-2, 101
4R-2, 102 White
5R-2, 99 Green
$5 R-5,124$ Green
$7 R-3,120$
$8 R-1,23$
$9 R-2,97$

9R-2, 97

522.43
524.08
524.09
533.45
537.93
554.18
559.73
565.57

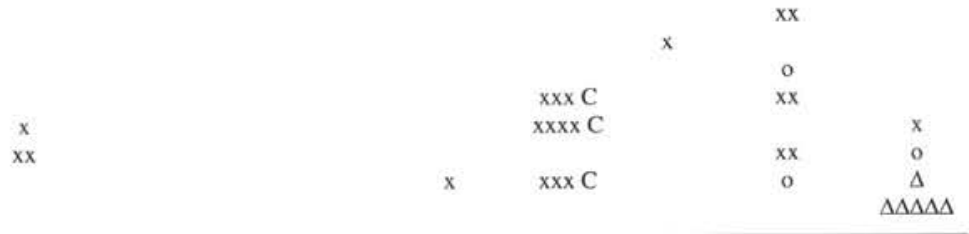

Notes: $-=$ traces; $0=$ present $x=$ relative abundance: $\Delta=$ mixture of volcanic minerals (with feldspars, pyroxenes, and olivine).

${ }^{\mathrm{a}} 10 \AA$ = clay minerals at $10 \AA$ as illite; $\mathrm{C}=$ celadonite.

volcanodetrital minerals, mainly feldspars.

${ }^{\text {c}}$ See text for full discussion.

Within the basal section of this unit of early to late Albian age, the slight volcaniclastic input yielded similar secondary paragenesis to that within the underlying deposit. Palygorskite, sometimes ascribed to volcanic phase alteration, is commonly found in silicified limestones and cherts and expresses the hypersilicic environment (Karpoff et al., 1981, and references therein).

\section{Upper Cretaceous Chert (Stage 5)}

As expected, the brown chert and porcellanite from both lithologic Units II (Sites 800 and 801) are made of quartz and opal-CT (with values for the main peak ranging from 4.06 to $4.11 \AA$ ). For the diagenetic implications of the relative abundances and characteristics 
Table 4 (continued).

\begin{tabular}{cccc}
\hline $\begin{array}{c}\text { Sample } \\
(\mathrm{cm}, \text { top })\end{array}$ & $\begin{array}{l}\text { Depth } \\
\text { (mbsf) }\end{array}$ & Other & $\begin{array}{c}\text { Stages and mineral } \\
\text { associations }\end{array}$ \\
\hline
\end{tabular}

129-801A-

$\begin{array}{lr}\text { IR-1, 40 } & 8.40 \\ \text { 3R-1, 63 } & 21.03 \\ \text { 3R-2, 145 } & 23.35 \\ \text { 5R-1, 13 } & 39.73 \\ \text { 5R-1, 15 } & 39.75 \\ \text { 5R-1, 62 } & 40.22 \\ \text { 5R-1, 63 } & 40.23 \\ \text { 7R-1, 67 } & 59.67 \\ & \\ \text { 7R-CC, 1 } & 63.96 \\ \text { 10R-1, 11 } & 87.61 \\ & \\ \text { 16R-1, 4 } & 145.64 \\ \text { 16R-1, 140 } & 147.00 \\ \text { 19R-1, 55 } & 175.25 \\ \text { 19R-1, 70 } & 175.35\end{array}$

129-801B.

\begin{tabular}{|c|c|c|c|}
\hline $2 \mathrm{R}-1,41$ & 203.91 & xx Analcime & (f) \\
\hline $3 \mathrm{R}-1,100$ & 213.90 & & \\
\hline $5 \mathrm{R}-1,50$ Green & 232.20 & & \\
\hline $5 \mathrm{R}-1,50$ Brown & 232.22 & & \\
\hline $5 R-2,84$ & 234.04 & & (e) \\
\hline $6 \mathrm{R}-4,62$ & 246.42 & & \\
\hline $7 \mathrm{R}-1,34$ & 251.34 & & \\
\hline $8 \mathrm{R}-1,130$ & 262.00 & & \\
\hline $8 R-5,102$ & 267.72 & $\ldots \ldots$ & \\
\hline 14R-1, 24 Gray & 318.54 & & \\
\hline 14R-1, 24 Pink & 318.55 & & \\
\hline $18 \mathrm{R}-1,24$ & 356.04 & & \\
\hline $24 \mathrm{R}-1,54$ & 401.14 & & \\
\hline $25 \mathrm{R}-1,1$ & 405.21 & & \\
\hline $27 \mathrm{R}-1,30$ & 415.00 & & \\
\hline $33 \mathrm{R}-1,43$ & 443.23 & Barite & \\
\hline $33 \mathrm{R}-1,143$ & 444.23 & Barite & \\
\hline $33 R-2,48$ & 444.78 & & \\
\hline $35 \mathrm{R}-2,120$ & 455.00 & & \\
\hline $35 \mathrm{R}-2,140$ & 455.20 & & \\
\hline 35R-3, I Red & 455.31 & Barite & \\
\hline 35R-3, 1 Yellow & 455.33 & Barite & \\
\hline $35 \mathrm{R}-3,19$ & 455.49 & & \\
\hline 44R-1, 125 Brown & 502.95 & $\mathrm{x}$ Ankerite & \\
\hline $44 \mathrm{R}-1,125$ Green & 502.96 & $\mathrm{xxx}$ Ankerite & \\
\hline $44 \mathrm{R}-1,132$ & 503.03 & Ankerite & \\
\hline
\end{tabular}

129-801C-

$\begin{array}{lll}\text { 4R-1, 73 } & 522.43 & \\ \text { 4R-2, 101 } & 524.08 & \\ \text { 4R-2, 102 White } & 524.09 & \\ 5 \mathrm{R}-2,99 \text { Green } & 533.45 & \\ 5 \mathrm{R}-5,124 \text { Green } & 537.93 & \\ 7 \mathrm{R}-3,120 & 554.18 \\ 8 \mathrm{R}-1,23 & 559.73 \\ \text { 9R-2, 97 } & 565.57 & \end{array}$

of these silica phases, see Behl and Smith (this volume). Accessory minerals are smectite and zeolites. The latter are prevalent clinoptilolite in opal-rich facies and scarce phillipsite within the uppermost interval of the unit at Site 800. Zeolites were not found in the few samples from this poorly recovered section at Site 801 . Scarce detrital feldspar also occurs at Site 800 . This facies is similar to the underlying sediments, with higher silica supply and strong diagenetic evolution. This facies is widespread in the northern Pacific (Larson, Moberly, et al., 1975; Thiede, Vallier, et al., 1981; Heath, Burckle, et al., 1985).

\section{Uppermost Cretaceous and Cenozoic Pelagic Red Clay} (Stage 6)

The latest episode consists of the slow deposition of deep-sea red clay below the CCD (Unit I-Sites 800 and 801 ). This facies contains the phases commonly found within the equivalent facies from Pacific deep basins: prevalent clay minerals, iron-oxides, and zeolites (Karpoff, 1989, and references therein). The manganese oxides that form micronodules do not give diffraction peaks, as they are amorphous phases. Halite is related to the high seawater content. The specificity to the red clays at Site 800 and 801 is the occurrence of relatively abundant detrital minerals (quartz, illite, scarce feldspar) in the uppermost part of the unit, and the vertical repartition of zeolites (Tables 3 and 4).

Phillipsite and clinoptilolite contents are negatively correlated; the latter is more abundant within the lower part of the unit. The relationship is progressive at Site 800 but emphasized at Site 801, where the nannofossil ooze interval is an effective border between the two levels of different mineralogy. As established by Kastner (1979, 1981), clinoptilolite appears to be the representative zeolite of the oldest condensed pelagic sediments (Upper Cretaceous), whereas phillipsite is better developed within Cenozoic deposits.

The fine fraction of the red clay is heterogeneous, comprising prevalent dioctahedral smectites, illite and interlayered minerals, kaolinite, chlorite, and quartz (Table 7). Palygorskite fibers are observed within TEM preparations (Pl. 4, Fig. 2). The detrital input from relatively close island sources is then obvious. The morphological segregation between detrital and authigenic smectites is sometimes difficult to determine; the latter appears more abundant within the lowermost part of these red clay units.

Lithologically comparable to the widespread recent deep-sea red clays in the central Pacific, the Pigafetta Basin red clay is more influenced by the detrital and eolian terrigenous input from nearby islands and continents, such as the deposit from the most northwestern part of the Pacific (Lenotre et al., 1985; Bryant and Bennett, 1988; Karpoff, 1989).

\section{GEOCHEMICAL COMPOSITION OF THE SEDIMENTS: THE MARK OF ENVIRONMENT}

Chemical data (Tables 8-11) are considered for all samples from Sites 800 and 801 . The major element compositions evidently reflect the petrographical composition of each facies. Whole sequences are silica-rich. The high silica contents relate both the biosedimentation, continuous during the long span of about $165 \mathrm{~m}$.y., and the subsequent intense diagenetic silicification. The minor and trace elements reflect the subtle differences of the deposits related to the variable inputs in various environments. Several types of diagrams allow the facies to be discriminated and related to the environments of deposition.

\section{Biosiliceous Background: Relationship to Plate Motion}

The variations in total silica content with depth are reflected as silica-rich chert, radiolarite, and silicified limestone. Pelagic input is diluted within the volcanogenic deposits and claystone. Variations of the $\mathrm{Si} / \mathrm{Al}$ ratio allow the main trend of biogenic input and diagenetic silicification to be specified (Figs. 4 and 5).

At Site 800 (Fig. 4), the curve for the maximum Si/Al ratio follows the paleolatitude curve. The highly chertified layers give the highest ratios; sites and episodes of intense silicification are near the basaltic basement (Early Cretaceous, stage 2) and during the early CampanianTuronian (stage 5). Considering also the calcite-rich facies occurring within Unit III (stage 4), the highest biogenic sedimentation ( $\mathrm{Si}$ and Ca) correlates with the nearest equatorial position of the site, during the Cenomanian. In these deposits the volcanogenic input decreases strongly as well (see "Mineral Associations" section above). A drastic 
Table 5. Mineralogical composition of the fine fraction $(<2 \mu \mathrm{m})$ of some samples of the Mesozoic siliceous biogenic deposits (Stages 1, 2, and 4).

\begin{tabular}{|c|c|c|c|c|c|c|c|}
\hline $\begin{array}{l}\text { Sample } \\
\text { (cm, top) }\end{array}$ & $\begin{array}{l}\text { Depth } \\
\text { (mbsf) }\end{array}$ & Stage & Smectites & Illite & $1-S$ & Palygorskite & Other \\
\hline \multicolumn{8}{|l|}{$129-800 \mathrm{~A}-$} \\
\hline $19 \mathrm{R}-1,37$ & 163.27 & 4 & $\mathrm{xxxx}$ & $x x$ & $x x$ & $x x$ & Opal \\
\hline $22 \mathrm{R}-1,19$ & 191.19 & 4 & $\operatorname{xxxxxxxxx}$ & $\mathrm{x}$ & & o & \\
\hline $51 \mathrm{R}-1,88$ & 450.48 & 2 & $\mathrm{xxxx}$ & $\mathrm{xx}$ & $\mathrm{xxx}$ & & x Quartz \\
\hline \multicolumn{8}{|l|}{ 129-801B- } \\
\hline $25 \mathrm{R}-1,1$ & 405.21 & 2 & $\operatorname{xxxxxx}$ & $x x$ & $x x$ & & Quartz \\
\hline $33 \mathrm{R}-1,43$ & 443.23 & 1 & $x x x$ & $x x x x x$ & $x x$ & & Quartz; broad $S$ peaks \\
\hline $35 \mathrm{R}-2,120$ & 455.00 & 1 & $\operatorname{xxxxxx}$ & $x$ & $\mathrm{xxx}$ & & \\
\hline $35 \mathrm{R}-2,140$ & 455.20 & 1 & $x x x x x$ & $x$ & $\mathrm{xxxx}$ & & Goethite, quartz \\
\hline 35R-3, 1 Red & 455.31 & 1 & $x x x x$ & $\mathrm{x}$ & $x x x x x$ & & Goethite, quartz \\
\hline $35 \mathrm{R}-3,19$ & 455.49 & 1 & $\operatorname{xxxxx}$ & $x$ & $x x x x$ & & Goethite, quartz \\
\hline
\end{tabular}

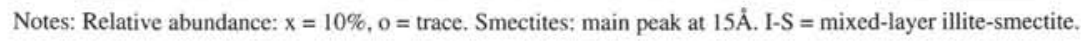

drop occurs at the chert-red clay boundary. The volcaniclastic deposits exhibit a constant $\mathrm{Si} / \mathrm{Al}$ ratio; the maxima are related to opal-rich intervals.

At Site 801 (Fig. 5), the Si/Al variations appears similar but less sharp. For the sedimentary cover, the maximum curve also follows the paleolatitude curve. Highly silicified intervals occur within the Upper Jurassic brown radiolarite (stage 2). The upper part of the crustal sequence displays a wide range of Si variations; highly silicified zones include the metasediments, a hydrothermal deposit, and an interlava flow breccia zone.

\section{Diagenetic Markers}

Strontium and barium are the trace elements commonly related to biogenic silica and calcium carbonate. During early diagenesis involving intense dissolution and recrystallization, these elements are released from the primary phases to secondary minerals or seawater. Some planktonic species (e.g., Acantharia, a radiolarian) exhibit a test made of celestine. $\mathrm{Sr}$ is frequently reused by the authigenic silicates (clay minerals and zeolites) and oxides, and depleted within highly trans-

Table 6. Mineralogical composition of the fine fraction $(<2 \mu \mathrm{m})$ of some intervals from Cretaceous volcaniclastic turbidites (Stage 3 ).

\begin{tabular}{|c|c|c|c|c|c|c|}
\hline $\begin{array}{c}\text { Sample } \\
\text { (cm, top) }\end{array}$ & $\begin{array}{l}\text { Depth } \\
\text { (mbsf) }\end{array}$ & Smectites & $10 \AA$ & I-S & $7 \AA$ & Other \\
\hline \multicolumn{7}{|l|}{$129-800 \mathrm{~A}-$} \\
\hline $26 \mathrm{R}-1,4$ & 228.64 & $x x x x x$ & $x x x x x$ & & & Clinoptilolite \\
\hline $26 \mathrm{R}-2.12$ & 230.22 & $x x x x x x x x x x$ & & & & \\
\hline $28 R-1.82$ & 248.02 & $x \times x x x \times x x$ & $x x$ & & & \\
\hline $28 R-4.2$ & 251.72 & $x x \times x x x x x x x$ & & & & \\
\hline 33R-2. 146 & 290.46 & $x x x x x x x x x$ & 0 & o & $x$ & \\
\hline $33 R-7.63$ & 296.33 & $x x x x x x x x x x$ & & o & & \\
\hline $35 R-2,98$ & 308.88 & $x x x x x x x x x x$ & & o & & Quartz \\
\hline $36 \mathrm{R}-2.39$ & 317.79 & 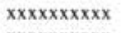 & & & 0 & \\
\hline $38 \mathrm{R}-1.12$ & 334.62 & $x x x x x x x x x x$ & & & & \\
\hline $38 \mathrm{R}-1.24$ & 334.74 & $x x x x x x x x x x$ & & & & Smectite at $14 \AA$ \\
\hline $41 R-1.93$ & 363.43 & $x x x x x x x x x$ & $x$ & & & \\
\hline \multicolumn{7}{|l|}{ 129-801B- } \\
\hline $16 \mathrm{R}-1.4$ & 145.64 & $x \times x \times x \times x$ & $\mathrm{xx}$ & $\mathrm{x}$ & & Clinoptilolite \\
\hline $19 \mathrm{R}-1.55$ & 175.25 & $x \times x \times x \times x x$ & $\mathrm{x}$ & $x$ & & \\
\hline \multicolumn{7}{|l|}{ 129-801C. } \\
\hline $3 R-1.100$ & 213.90 & $x x x x x x x x x x x$ & & & & Smectite at $13 \AA$ \\
\hline $5 R-2,84$ & 234.04 & $x x x x x x x x x$ & $x$ & & & Smectite at $14.5 \AA$ \\
\hline $6 R-4,62$ & 246.42 & $x x x x x x x x$ & $\mathrm{xx}$ & & & \\
\hline 8R-5. 102 & 267.72 & $x x x x x x x x$ & 0 & $x \mathrm{x}$ & & Clinoptilolite: broader peaks \\
\hline
\end{tabular}

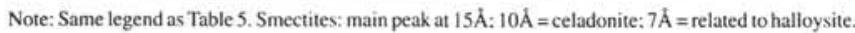

formed calcareous sediments (Veizer and Demovic, 1974; Karpoff, 1980, 1989; Manghnani et al., 1980; Garrison, 1981). The sediments from Sites 800 and 801 are mostly Ca-poor (Fig. 6). The Sr/Ca ratio of the Paleocene nannofossil ooze (Site 801-Unit I, stage 6) is like that of Cenozoic calcareous sediments. The calcitic beds from the silicified sediments from Site 800-Unit III (stage 4) are Sr-depleted, as is the ankerite-rich metasediment (Site 801 basalt sequence), indicating intense carbonate recrystallization. Among the siliceous facies with low $\mathrm{Sr}$ contents, the Jurassic basal red radiolarite (stage 1) has the higher $\mathrm{Sr}$ content. This facies is also barite-rich (Tables 4 and 11). A hydrothermal origin could also be evoked for $\mathrm{Sr}$ and $\mathrm{Ba}$ enrichments; nevertheless, the fairly preserved radiolarian fauna (Matsuoka, this volume), the medium compaction, and the relatively high water content of the sediment are arguments for a biogenic source and the preservation of $\mathrm{Ba}$ and $\mathrm{Sr}$ in this basal deposit.

The volcaniclastic sequence and the Cenozoic red clay are Sr-enriched; both alterations of biogenic phases and volcanic detritus supply the Sr enrichment of the secondary zeolites and clay minerals. Further isotopic analyses would discriminate the $\mathrm{Sr}$ origins in these facies (Hoffert et al., 1978; Clauer et al., 1982).

\section{Geochemical Expression of the Contribution of Basaltic Crust and Volcanogenic Phases}

In the pelagic realm, which is free of significant detrital input, major elements were derived from biogenic phases ( $\mathrm{Si}, \mathrm{Ca}$, and minor $\mathrm{Fe}$ and $\mathrm{Mn}$ ), from halmyrolysis of basaltic and volcanic phases ( $\mathrm{Si}$, $\mathrm{Fe}$, and to lesser extent $\mathrm{Mn}$ and $\mathrm{Al}$ ), and from hydrothermal fluids ( $\mathrm{Fe}$, $\mathrm{Mn}$, and $\mathrm{Si}$ ). The relationships among these major elements, and the related trace elements, define the various contributions of the primary phases and the environment of deposition. Analog diagrams such as those used by Boström (1970), Bonatti et al. (1972), Dymond et al. (1973), Toth (1980), and Bonatti (1981) are useful to discriminate the pelagic facies and enable the formation of hypotheses for similar origins of comparable sediments (Karpoff, 1989; Karpoff et al., 1985, 1988 , and references therein).

The relationships between $\mathrm{Fe} / \mathrm{Ti}$ and $\mathrm{Al} / \mathrm{Al}+\mathrm{Fe}+\mathrm{Mn}$ ratios differentiate detrital (as continental crust), basaltic (as mid-ocean ridge basalt), and hydrothermal (as East Pacific Rise, or EPR, deposits) contributions (Fig. 7). The value less than 0.4 for $\mathrm{Al} / \mathrm{Al}+\mathrm{Fe}+$ $\mathrm{Mn}$ ratio is indicative of metal enrichment of sediment (Boström, 1970, 1983). The main facts are:

1. Siliceous ochre, metasediments, celadonite-rich interpillow deposits, and breccia zones, all from the basaltic upper sequence, have a strong hydrothermal signature, 
Table 7. Mineralogical composition of the fine fraction $(<2 \mu \mathrm{m})$ of the Cenozoic pelagic red clay (Stage 1).

\begin{tabular}{|c|c|c|c|c|c|c|c|}
\hline $\begin{array}{c}\text { Sample } \\
\text { (cm, top) }\end{array}$ & $\begin{array}{l}\text { Depth } \\
\text { (mbsf) }\end{array}$ & Smectites & Illite & I-S & Kaolinite & Chlorite & Other \\
\hline \multicolumn{8}{|l|}{$128-800 \mathrm{~A}-$} \\
\hline IR-CC, 1 & 0.28 & $\operatorname{xxxxx}$ & $x x x$ & & $x$ & $\mathrm{x}$ & Quartz \\
\hline $3 \mathrm{R}-1,136$ & 11.96 & $\operatorname{xxxxxx}$ & $x x x$ & & $x$ & o & Quartz \\
\hline $4 \mathrm{R}-1,97$ & 21.27 & $\operatorname{xxxxxxx}$ & $x x$ & o & $\mathrm{x}$ & & Quartz. \\
\hline $4 \mathrm{R}-3,80$ & 24.00 & $\operatorname{xxxxxxx}$ & $x x$ & o & $\mathrm{x}$ & & Quartz \\
\hline $4 \mathrm{R}-4,17$ & 24.87 & $\operatorname{xxxxxxx}$ & $\mathrm{x}$ & $\mathrm{x}$ & $\mathrm{x}$ & & Quartz \\
\hline \multicolumn{8}{|l|}{$129-801 \mathrm{~A}-$} \\
\hline IR-1, 40 & 8.40 & $\operatorname{xxxxx}$ & $x x$ & $\mathrm{x}$ & $\mathrm{x}$ & $x$ & Quartz. \\
\hline $3 \mathrm{R}-1,63$ & 21.03 & $x x x x x$ & $x x$ & $\mathrm{x}$ & $\mathrm{x}$ & $x$ & Quartz. \\
\hline SR-1, 13 & 39.73 & $\operatorname{xxxxxxx}$ & $x x$ & $\mathrm{x}$ & o & & \\
\hline 5R-1, 62 Ca-ooze & 40.22 & $\mathrm{xxxxxx}$ & $x x$ & $\mathrm{xx}$ & & & Very broad peaks \\
\hline $5 \mathrm{R}-1,63$ & 40.23 & $\operatorname{xxxxxxx}$ & $\mathrm{x}$ & $x x$ & o & o & \\
\hline $7 R-1.67$ & 59.67 & xxxxxxxx & $\mathrm{x}$ & $\mathrm{x}$ & & & \\
\hline
\end{tabular}

Note: Same legend as Table 5 .

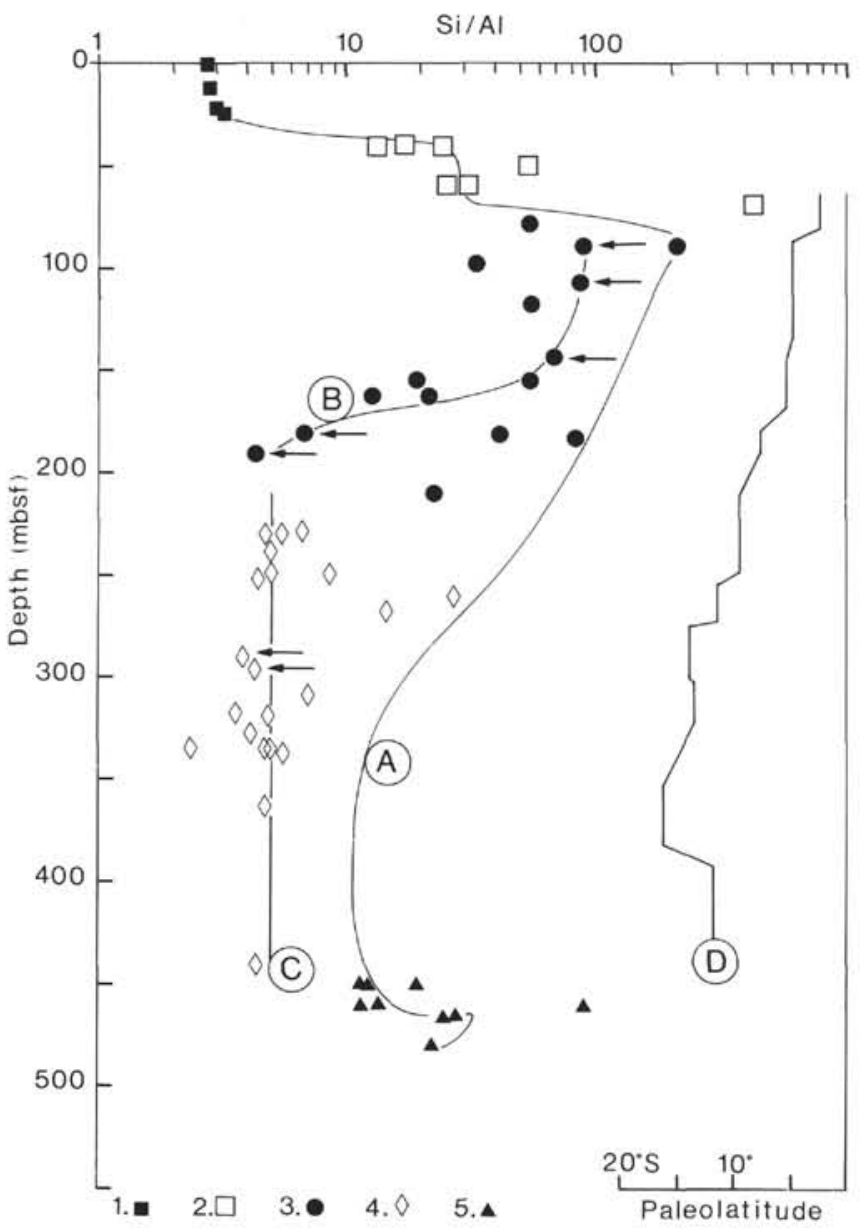

Figure 4. Variation of $\mathrm{Si} / \mathrm{Al}$ ratio vs. depth in sediments from Site 800 . A. Curve of the maximum biogenic silica input. B. Possible curve of biogenic calcite input and arrows showing the calcite-rich samples. C. Average line for volcaniclastic deposits. D. Paleolatitude curve (from Lancelot, Larson, et al., 1990). Key to symbols: (1) pelagic red clay (stage 6); (2) brown chert (stage 5); (3) chert and silicified limestone (stage 4); (4) volcaniclastic turbidites (stage 3); and (5) clayey radiolarite (stage 2 ).

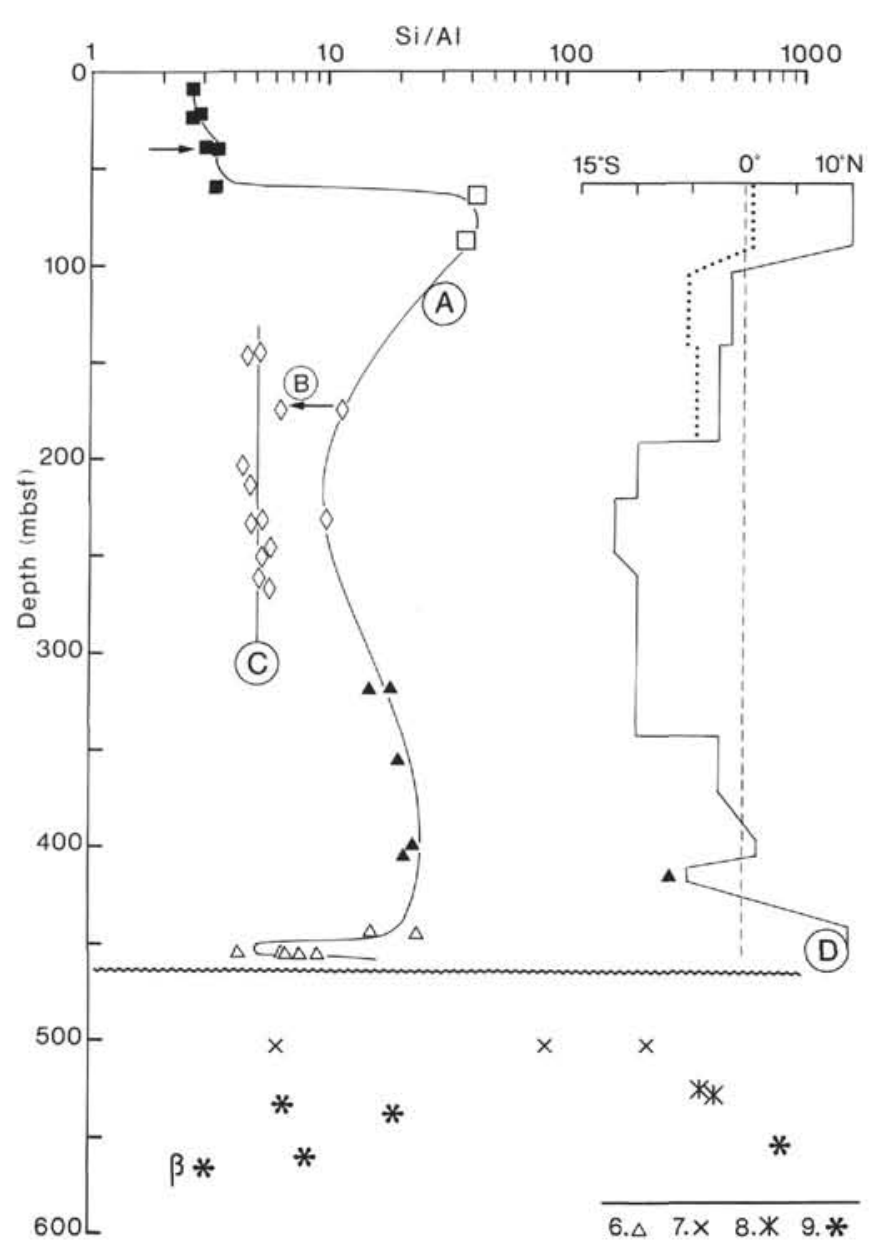

Figure 5. Variation of $\mathrm{Si} / \mathrm{Al}$ ratio vs. depth in sediments and alteration products of basaltic basement from Site 801. A-D. Same curves as in Figure 4. (Dashed line in (D) is error value). Key to symbols ( 1 to 5 ) same as in Figure 4 ; (6) Jurassic basal red radiolarite and claystone (stage 1); (7) metasediments; (8) hydrothermal deposit; and (9) interpillows material and basalt ( $\beta)$. 


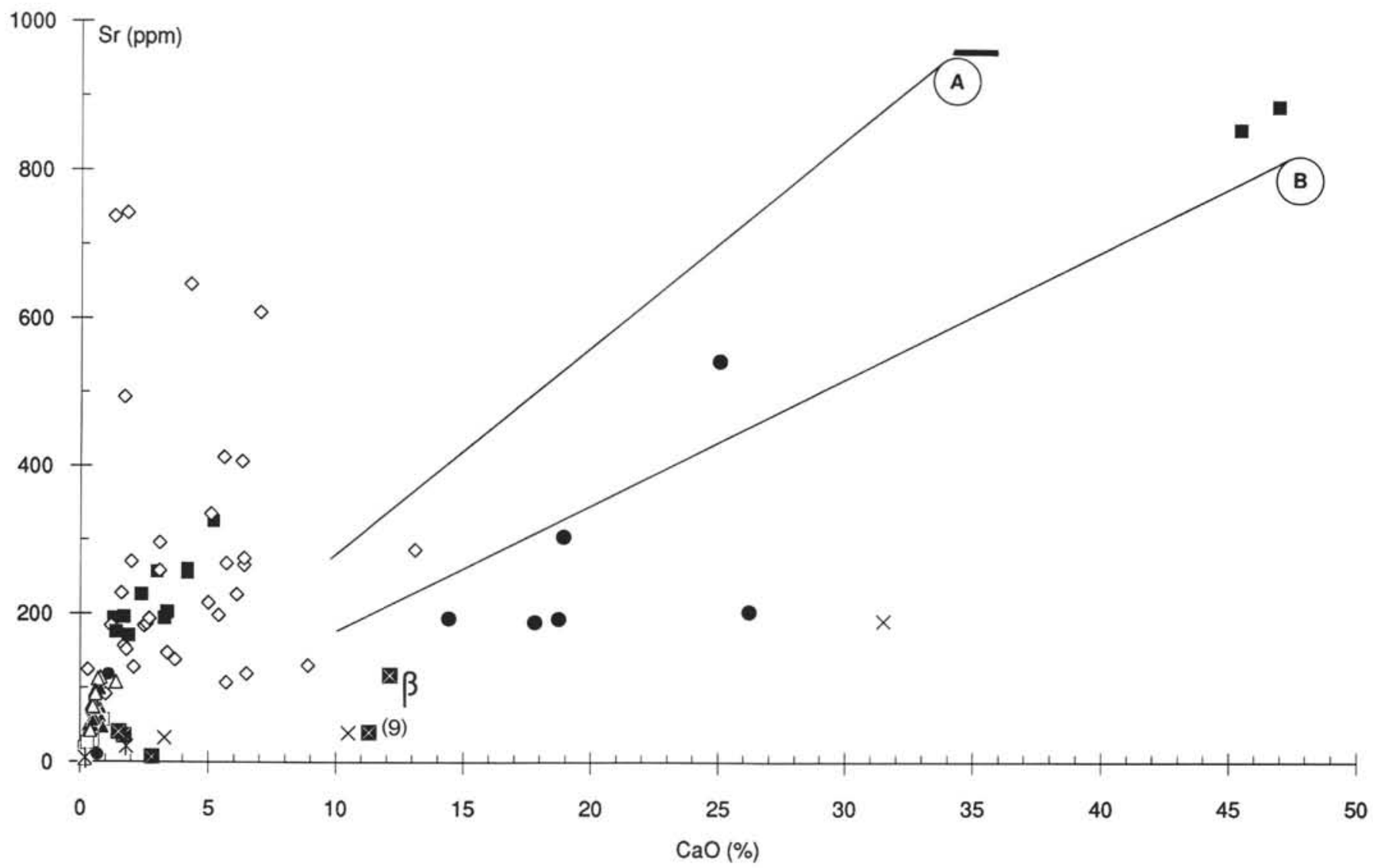

Figure 6. Relationship between $\mathrm{CaO}$ and $\mathrm{Sr}$ contents in lithologic facies from Sites 800 and 801 . Key to symbols same as in Figures 4 and 5 (1 to 8 ), (9) white-cross squares for basement samples. A. Relation of $\mathrm{Sr}$-Ca in the recent surface sediments, after Baker et al. (1982). B. Relation of Sr-Ca in Miocene calcareous oozes, after Graham et al. (1982).

2. Jurassic basal red radiolarite and claystone (stage 1) show a significant metal enrichment (and light trace metal enrichment, $\mathrm{V}, \mathrm{Zn}$, and $\mathrm{Zr}$ ),

3. Brown radiolarite from stage 2 is intermediate between the Jurassic basal red radiolarite and younger siliceous deposits (stages 4 to 5),

4. The volcanogenic supply (e.g., stage 3 ) to the biogenic sedimentation during stage 4 is well expressed,

5. The latest deposits, Campanian chert to Cenozoic red clay (stages 5 and 6), contain a detrital component.

Detailed geochemical discrimination between the successive biosiliceous sediments is given by Karl et al. (this volume).

These geochemical specifics are also shows by the $\mathrm{Ti}$ and $\mathrm{Fe}$ relationship (Fig. 8), which emphasizes iron enrichment of the products of altered basalt, particularly the interpillow celadonite, the iron enrichment of the basal red radiolarite with respect to the other siliceous sediments, and the titanium enrichment of the altered volcaniclastics with respect to the tholeiitic basalt reference. These high $\mathrm{Ti}$ contents, as well as the higher $\mathrm{Zr}$ contents, could also reflect a specific magmatic source for the volcanogenic phase. The red radiolarite samples are located between the hydrothermal trend in the basaltic crust and the halmyrolytic trend represented within the volcaniclastic deposits and Cenozoic pelagic clay. The latter are distinguished from each other by their $\mathrm{Al}$ contents. Possible contamination by a Fe- $\mathrm{Zn}-\mathrm{Cr}$ component is suspected in the uppermost superficial red clay corecatcher sample: this does not affect the ratio between other elements.

A ternary plot of Al-Fe-Mn allows the Pigafetta Basin deposits and other oceanic facies to be compared (Fig. 9). The data points for Cenozoic pelagic clay, UpperCretaceous chert, and Aptian-Cenomanian chert and limestone (stages 6, 5, and 4) are within the field of biogenic oozes, between the terrigenous end-member and the diagenetic deep-sea brown clays field. The points representative of the Lower Cretaceous to Upper Jurassic radiolarite and claystone (stage 2) reach the field of metalliferous sediments (EPR and Bauer Deep deposits). The Callovian-Bathonian basal radiolarite samples have their points between the basaltic pole and the Fe apex of the hydrothermal field. This trend appears to be that of the highly siliceous sediments formed close to basaltic basement. The metasediments, siliceous ochre, and alteration products from the crustal sequence lie within the hydrothermal field, which is also that of the interlava flow sediments from the Oman ophiolite (Robertson and Fleet, 1986; Karpoff et al., 1988).

The Bonatti ternary diagram [ Fe-Mn- $(\mathrm{Ni}+\mathrm{Co}+\mathrm{Cu}) \times 10]$ (Fig. 10) is primarily used as a classification to discriminate among the various oceanic metalliferous concretions and nodules as hydrogenous (from seawater), hydrothermal, or diagenetic (seawater-sediments interaction). With increasing data on such phases and on their host sediments, the apex significance and trends can be specified (Toth, 1980; Karpoff et al., 1985; Karpoff, 1989). The Fe apex area is characteristic of hydrothermal metallic ores and biogenic oozes. The diagenetic evolution of the latter yields the segregation between deep-sea nodules (hydrogenous and oxic diagenetic apex) and their host red clays. The Mn zone is the field of transition-element-poor hydrothermal crust, but also of biogenic origin and crusts formed at shallow depths (suboxic diagenetic environment). In these cases, the Mn concretions are enriched in other trace elements, particularly $\mathrm{Ba}$ and $\mathrm{Sr}$.

The data confirm the hydrothermal character of the alteration products in the basaltic sequence, and also that of the Middle Jurassic basal red radiolarite (stage 1). The subsequent sediments (radiolarite 
Table 8. Chemical composition of bulk samples of sediments from Site 800: major elements (wt \%).

\begin{tabular}{|c|c|c|c|c|c|c|c|c|c|c|c|c|c|}
\hline $\begin{array}{l}\text { Sample } \\
\text { (cm, top) }\end{array}$ & $\begin{array}{l}\text { Depth } \\
\text { (mbsf) }\end{array}$ & $\mathrm{SiO}_{2}$ & $\mathrm{Al}_{2} \mathrm{O}_{3}$ & $\mathrm{MgO}$ & $\mathrm{CaO}$ & $\mathrm{Fe}_{2} \mathrm{O}_{3}$ & $\mathrm{Mn}_{3} \mathrm{O}_{4}$ & $\mathrm{TiO}_{2}$ & $\mathrm{Na}_{2} \mathrm{O}$ & $\mathrm{K}_{2} \mathrm{O}$ & $\mathrm{P}_{2} \mathrm{O}_{5}$ & LOI & Total \\
\hline \multicolumn{14}{|l|}{$128-800 \mathrm{~A}-$} \\
\hline IR-CC, I & 0.28 & 46.1 & 14.6 & 3.03 & 1.3 & 15.8 & 1.310 & 0.78 & 3.58 & 2.69 & 0.41 & 9.93 & 99.53 \\
\hline $3 R-1,136$ & 11.96 & 48.5 & 15.3 & 3.15 & 3.0 & 7.6 & 2.690 & 0.66 & 3.69 & 3.52 & 1.56 & 10.83 & 100.50 \\
\hline $4 \mathrm{R}-1,97$ & 21.27 & 50.2 & 14.7 & 3.18 & 4.2 & 6.6 & 2.340 & 0.63 & 3.10 & 3.71 & 2.30 & 9.61 & 100.57 \\
\hline $4 \mathrm{R}-3,80$ & 24.00 & 50.6 & 14.3 & 2.77 & 5.2 & 5.4 & 2.110 & 0.53 & 3.16 & 4.19 & 2.87 & 9.01 & 100.14 \\
\hline $4 \mathrm{R}-4,17$ & 24.87 & 50.8 & 14.0 & 2.92 & 4.2 & 5.7 & 1.820 & 0.57 & 2.33 & 3.87 & 2.38 & 10.31 & 98.90 \\
\hline $6 \mathrm{R}-1,7$ & 39.67 & 85.5 & 4.4 & 1.04 & 0.4 & 2.0 & 0.274 & 0.20 & 1.00 & 1.07 & 0.14 & 4.30 & 100.32 \\
\hline 6R-1, 37 Clear & 39.97 & 80.8 & 5.3 & 1.36 & 0.7 & 2.5 & 0.438 & 0.23 & 1.14 & 1.38 & 0.40 & 5.54 & 99.79 \\
\hline 6R-1,38 Dark & 39.98 & 90.0 & 3.2 & 0.73 & 0.4 & 1.4 & 0.244 & 0.16 & 0.66 & 0.78 & 0.16 & 3.62 & 101.35 \\
\hline $7 \mathrm{R}-1,66$ & 49.86 & 92.0 & 1.5 & 0.42 & 0.2 & 1.0 & 0.204 & 0.13 & 0.39 & 0.44 & 0.05 & 2.74 & 99.07 \\
\hline $8 \mathrm{R}-1,1$ & 58.91 & 87.5 & 2.9 & 0.90 & 0.9 & 1.5 & 0.216 & 0.15 & 0.70 & 0.66 & 0.45 & 3.90 & 99.78 \\
\hline $8 \mathrm{R}-1,22$ & 59.12 & 89.0 & 2.5 & 0.83 & 0.2 & 1.3 & 0.113 & 0.14 & 0.70 & 0.69 & 0.12 & 3.50 & 99.09 \\
\hline $9 \mathrm{R}-1,1$ & 68.51 & 96.5 & 0.2 & 0.08 & 0.2 & 0.3 & 0.010 & 0.03 & 0.09 & 0.10 & 0.05 & 1.71 & 99.27 \\
\hline $10 \mathrm{R}-1,13$ & 78.33 & 92.8 & 1.5 & 0.33 & 0.2 & 1.7 & 0.010 & 0.16 & 0.37 & 0.48 & 0.05 & 2.85 & 100.45 \\
\hline $11 \mathrm{R}-1,90$ Clear & 88.70 & 63.3 & 0.6 & 0.29 & 18.9 & 0.5 & 0.063 & 0.06 & 0.21 & 0.30 & 0.05 & 16.33 & 100.60 \\
\hline 11R-1,91 Dark & 88.71 & 95.0 & 0.4 & 0.14 & 0.5 & 0.3 & 0.010 & 0.05 & 0.16 & 0.22 & 0.05 & 1.82 & 98.65 \\
\hline $12 \mathrm{R}-1,37$ & 97.67 & 90.6 & 2.4 & 0.75 & 0.3 & 1.3 & 0.011 & 0.16 & 0.51 & 0.88 & 0.12 & 2.62 & 99.65 \\
\hline $13 \mathrm{R}-1,46$ & 107.26 & 69.1 & 0.7 & 0.25 & 14.4 & 0.5 & 0.028 & 0.10 & 0.22 & 0.26 & 0.05 & 13.33 & 98.94 \\
\hline $14 \mathrm{R}-1,101$ & 117.21 & 93.0 & 1.5 & 0.54 & 0.3 & 1.1 & 0.010 & 0.13 & 0.44 & 0.57 & 0.05 & 2.52 & 100.16 \\
\hline $17 \mathrm{R}-1,25$ & 144.45 & 62.2 & 0.8 & 0.36 & 18.7 & 0.5 & 0.081 & 0.10 & 0.24 & 0.28 & 0.05 & 16.52 & 99.83 \\
\hline $18 \mathrm{R}-1,70$ & 154.40 & 83.6 & 3.9 & 1.28 & 0.7 & 2.9 & 0.021 & 0.37 & 0.92 & 1.14 & 0.19 & 3.63 & 98.65 \\
\hline $18 \mathrm{R}-1,121$ & 154.91 & 92.0 & 1.5 & 0.51 & 0.3 & 1.1 & 0.013 & 0.15 & 0.50 & 0.50 & 0.05 & 2.33 & 98.95 \\
\hline $19 \mathrm{R}-1,1$ & 162.91 & 85.5 & 3.5 & 1.24 & 0.4 & 2.5 & 0.013 & 0.28 & 0.69 & 1.13 & 0.05 & 3.59 & 98.89 \\
\hline $19 \mathrm{R}-1,37$ & 163.27 & 80.1 & 5.5 & 1.90 & 0.5 & 4.4 & 0.033 & 0.46 & 0.97 & 1.68 & 0.15 & 5.00 & 100.69 \\
\hline $21 \mathrm{R}-1,54$ Gray & 181.84 & 69.0 & 9.0 & 3.61 & 1.0 & 6.8 & 0.049 & 0.70 & 1.49 & 2.55 & 0.24 & 5.67 & 100.11 \\
\hline $21 \mathrm{R}-1,56$ White & 181.86 & 61.5 & 1.3 & 0.53 & 17.8 & 0.9 & 0.046 & 0.12 & 0.38 & 0.33 & 0.11 & 16.40 & 99.42 \\
\hline $21 \mathrm{R}-2,8$ & 182.88 & 48.7 & 0.5 & 0.31 & 26.2 & 0.3 & 0.086 & 0.08 & 0.17 & 0.11 & 0.05 & 23.10 & 99.61 \\
\hline $22 \mathrm{R}-1,19$ & 191.19 & 33.6 & 6.7 & 2.27 & 25.0 & 5.2 & 0.068 & 1.08 & 1.27 & 0.84 & 0.19 & 24.20 & 100.42 \\
\hline $24 \mathrm{R}-1,30$ & 210.20 & 85.3 & 3.3 & 1.20 & 0.5 & 2.7 & 0.072 & 0.31 & 0.73 & 0.93 & 0.05 & 3.28 & 98.37 \\
\hline $26 \mathrm{R}-1,4$ & 228.64 & 62.3 & 8.3 & 4.44 & 1.8 & 7.6 & 0.137 & 1.35 & 2.32 & 2.86 & 0.19 & 7.12 & 98.42 \\
\hline $26 \mathrm{R}-1,106$ & 229.66 & 55.6 & 8.9 & 6.56 & 7.0 & 7.9 & 0.161 & 1.45 & 2.28 & 1.79 & 0.21 & 7.52 & 99.37 \\
\hline $26 \mathrm{R}-2,12$ & 230.22 & 52.9 & 9.7 & 9.93 & 6.4 & 10.3 & 0.239 & 1.63 & 2.05 & 0.43 & 0.27 & 5.28 & 99.13 \\
\hline $27 \mathrm{R}-1,30$ & 238.30 & 57.2 & 10.2 & 6.08 & 6.3 & 9.5 & 0.162 & 1.73 & 2.63 & 0.98 & 0.19 & 5.19 & 100.16 \\
\hline $28 \mathrm{R}-1,82$ & 248.02 & 52.6 & 9.4 & 12.30 & 3.1 & 10.7 & 0.170 & 1.18 & 2.33 & 1.69 & 0.20 & 5.73 & 99.40 \\
\hline $28 \mathrm{R}-2,48$ & 249.18 & 72.3 & 7.4 & 3.29 & 1.3 & 3.7 & 0.061 & 0.56 & 2.05 & 1.47 & 0.18 & 6.40 & 98.71 \\
\hline $28 \mathrm{R}-4,2$ & 251.72 & 50.0 & 10.0 & 11.20 & 6.4 & 9.5 & 0.226 & 1.28 & 2.68 & 0.80 & 0.25 & 6.11 & 98.45 \\
\hline $29 \mathrm{R}-3,72$ & 260.22 & 87.0 & 2.8 & 1.41 & 0.5 & 2.4 & 0.050 & 0.22 & 0.68 & 0.93 & 0.05 & 3.37 & 99.41 \\
\hline $30 \mathrm{R}-2,25$ & 267.65 & 77.9 & 4.7 & 1.82 & 1.2 & 5.2 & 0.092 & 0.62 & 1.39 & 0.74 & 0.14 & 4.75 & 98.55 \\
\hline $33 R-2,146$ & 290.46 & 45.3 & 10.4 & 6.08 & 13.1 & 10.0 & 0.172 & 1.69 & 2.18 & 1.18 & 0.23 & 9.92 & 100.25 \\
\hline $33 \mathrm{R}-7,63$ & 296.33 & 46.4 & 9.5 & 10.80 & 6.5 & 9.3 & 0.162 & 1.36 & 1.64 & 2.95 & 0.18 & 9.85 & 98.64 \\
\hline $35 R-2,98$ & 308.88 & 63.5 & 7.9 & 5.87 & 1.7 & 9.6 & 0.098 & 0.91 & 1.70 & 1.81 & 0.17 & 6.53 & 99.79 \\
\hline $36 \mathrm{R}-2,39$ & 317.79 & 46.1 & 11.3 & 6.90 & 8.9 & 10.0 & 0.216 & 1.59 & 1.47 & 2.90 & 0.27 & 10.95 & 100.60 \\
\hline $36 \mathrm{R}-3,28$ & 319.18 & 49.7 & 9.0 & 17.40 & 2.1 & 10.1 & 0.181 & 0.99 & 2.83 & 1.00 & 0.26 & 6.87 & 100.43 \\
\hline $37 \mathrm{R}-\mathrm{CC}, 1$ & 328.02 & 44.7 & 9.5 & 13.50 & 5.7 & 11.7 & 0.305 & 1.68 & 1.92 & 0.86 & 0.25 & 8.41 & 98.53 \\
\hline $38 \mathrm{R}-1,12$ & 334.62 & 55.3 & 9.7 & 11.70 & 2.5 & 9.7 & 0.191 & 1.49 & 2.38 & 1.21 & 0.18 & 6.82 & 101.17 \\
\hline $38 \mathrm{R}-1,24$ & 334.74 & 52.8 & 9.8 & 8.43 & 2.0 & 10.7 & 1.270 & 1.35 & 2.28 & 1.52 & 0.27 & 8.21 & 98.63 \\
\hline $38 \mathrm{R}-1,29$ Nodule & 334.79 & 1.6 & 0.6 & 0.20 & 0.3 & 0.3 & 82.100 & 0.14 & 0.05 & 0.05 & 0.05 & 13.60 & 98.99 \\
\hline $39 \mathrm{R}-2,111$ & 337.15 & 54.2 & 8.6 & 11.60 & 1.8 & 9.9 & 0.117 & 1.37 & 2.24 & 1.04 & 0.17 & 7.25 & 98.29 \\
\hline $41 \mathrm{R}-1,93$ & 363.43 & 49.7 & 9.3 & 12.60 & 3.7 & 11.8 & 0.222 & 1.30 & 1.95 & 1.38 & 0.40 & 6.82 & 99.17 \\
\hline $50 R-1,59$ & 440.79 & 55.9 & 11.2 & 8.45 & 1.0 & 8.3 & 0.033 & 0.92 & 1.49 & 6.33 & 0.05 & 4.78 & 98.45 \\
\hline $51 \mathrm{R}-1,88$ & 450.48 & 80.8 & 5.9 & 1.83 & 0.8 & 3.7 & 0.089 & 0.38 & 1.00 & 1.60 & 0.27 & 3.83 & 100.20 \\
\hline 51R-1, 135 Clear & 450.95 & 79.9 & 5.6 & 1.50 & 0.7 & 3.8 & 0.150 & 0.37 & 0.87 & 1.54 & 0.13 & 3.63 & 98.19 \\
\hline 51R-1, 136 Dark & 450.96 & 83.3 & 3.7 & 1.25 & 0.8 & 4.1 & 0.308 & 0.35 & 0.70 & 1.14 & 0.16 & 2.87 & 98.68 \\
\hline $52 \mathrm{R}-1,141$ & 460.21 & 82.5 & 5.2 & 1.43 & 0.7 & 3.5 & 1.170 & 0.31 & 0.77 & 1.35 & 0.11 & 3.24 & 100.28 \\
\hline $52 \mathrm{R}-2,86$ & 461.16 & 78.3 & 5.8 & 1.64 & 0.8 & 5.2 & 0.537 & 0.36 & 0.99 & 1.71 & 0.19 & 3.71 & 99.24 \\
\hline 52R-2, 86 Fissure & 461.20 & 95.7 & 0.9 & 0.29 & 0.3 & 0.9 & 0.332 & 0.08 & 0.27 & 0.30 & 0.05 & 0.94 & 100.06 \\
\hline $53 \mathrm{R}-1,117$ & 466.07 & 87.7 & 2.7 & 0.90 & 0.5 & 2.3 & 0.284 & 0.17 & 0.36 & 0.78 & 0.05 & 2.61 & 98.35 \\
\hline $53 R-2,25$ Pink & 466.65 & 86.7 & 2.9 & 0.92 & 0.9 & 2.9 & 0.085 & 0.18 & 0.36 & 0.89 & 0.12 & 2.47 & 98.43 \\
\hline 53R-2, 27 Brown & 466.67 & 87.8 & 3.0 & 0.92 & 0.5 & 2.9 & 0.357 & 0.20 & 0.66 & 0.97 & 0.13 & 2.63 & 100.07 \\
\hline $55 \mathrm{R}-1,126$ & 480.36 & 88.5 & 3.4 & 0.88 & 0.5 & 2.2 & 0.143 & 0.18 & 0.61 & 1.13 & 0.12 & 2.49 & 100.15 \\
\hline
\end{tabular}

and claystone from the Late Jurassic-Early Cretaceous, stage 2) retain this metalliferous specificity, with a high $\mathrm{Fe} / \mathrm{Mn}$ ratio; however, the $\mathrm{Mn}$ enrichment is followed by a slight trace element concentration related to early oxic diagenesis (micronodules replacing tests). The high Si content of the chert (stage 4), as well as the detrital feature of the Mn-enriched-pelagic clay (stage 6), disperse the representative points on both side of the biogenic-diagenetic trendline.

A peculiarity of the volcaniclastic deposits from Site 800 is the manganite which forms concretions and vein infillings. The chemical composition of this manganese phase has a representative point lying within the hydrothermal field; but, as with the Mn-microconcretions from Site 550 Paleocene chert (Karpoff et al., 1985), this manganite has a very high Ba content with lesser amounts of Sr. The Atlantic Paleocene micronodules are fecal pellets made up of diatomaceous fragments diagenetically replaced by well-crystallized todorokite. The manganite concretions at Site 800 , like the pellets, are massive and do not show any columnar or concentric layering of deep-sea nodules; nevertheless, no traces of biogenic tests were found (PI. 2, Fig. 1). A probable primarily biogenic origin of the manganese oxides concentration is suspected; these oxides could have formed at shallow depths and settled with the turbidites beds. These concretions yielded a secondary diagenetic transformation onto the better-crystallized 
Table 9. Chemical composition of bulk samples of sediments from Site 800: trace elements (ppm).

\begin{tabular}{|c|c|c|c|c|c|c|c|c|c|c|}
\hline $\begin{array}{c}\text { Sample } \\
\text { (cm, top) }\end{array}$ & $\begin{array}{l}\text { Depth } \\
\text { (mbsf) }\end{array}$ & $\mathrm{Sr}$ & $\mathrm{Ba}$ & $\mathrm{v}$ & $\mathrm{Ni}$ & Co & $\mathrm{Cu}$ & $\mathrm{Cr}$ & $\mathrm{Zn}$ & $\mathrm{Zr}$ \\
\hline \multicolumn{11}{|l|}{ 129-800A- } \\
\hline IR-CC, 1 & 0.28 & 195 & 450 & 188 & 250 & 140 & 312 & 759 & 1882 & 190 \\
\hline $3 \mathrm{R}-1,136$ & 11.96 & 258 & 375 & 139 & 455 & 240 & 264 & 60 & 167 & 176 \\
\hline $4 \mathrm{R}-1,97$ & 21.27 & 256 & 395 & 120 & 507 & 230 & 290 & 50 & 158 & 166 \\
\hline $4 \mathrm{R}-3,80$ & 24.00 & 326 & 317 & 106 & 495 & 188 & 346 & 39 & 123 & 159 \\
\hline $4 \mathrm{R}-4,17$ & 24.87 & 262 & 348 & 101 & 340 & 164 & 277 & 44 & 205 & 154 \\
\hline $6 \mathrm{R}-1,7$ & 39.67 & 40 & 85 & 33 & 38 & 22 & 87 & 19 & 81 & 54 \\
\hline 6R-1, 37 Clear & 39.97 & 59 & 150 & 37 & 44 & 29 & 138 & 19 & 98 & 60 \\
\hline $6 \mathrm{R}-1,38$ Dark & 39.98 & 30 & 64 & 25 & 55 & 16 & 60 & 18 & 61 & 40 \\
\hline $7 \mathrm{R}-1,66$ & 49.86 & 17 & 59 & 15 & 7 & 6 & 32 & 12 & 385 & 27 \\
\hline $8 \mathrm{R}-1,1$ & 58.91 & 57 & 62 & 22 & 23 & 18 & 85 & 16 & 72 & 44 \\
\hline $8 R-1,22$ & 59.12 & 19 & 57 & 19 & 1 & 7 & 48 & 14 & 54 & 36 \\
\hline $9 \mathrm{R}-1,1$ & 68.51 & 4 & 39 & 7 & 1 & 10 & 14 & 8 & 10 & 7 \\
\hline $10 \mathrm{R}-1,13$ & 78.33 & 16 & 214 & 40 & 5 & 5 & 42 & 31 & 42 & 29 \\
\hline IIR-1,90 Clear & 88.70 & 306 & 392 & 11 & 22 & 14 & 15 & 10 & 15 & 15 \\
\hline IIR-1,91 Dark & 88.71 & 12 & 14 & 9 & 53 & 21 & 7 & 8 & 11 & 12 \\
\hline $12 \mathrm{R}-1,37$ & 97.67 & 25 & 291 & 39 & 26 & 16 & 20 & 30 & 30 & 37 \\
\hline $13 \mathrm{R}-1,46$ & 107.26 & 195 & 84 & 9 & 13 & 8 & 16 & 11 & 16 & 15 \\
\hline $14 \mathrm{R}-1,101$ & 117.21 & 19 & 127 & 20 & 28 & 18 & 20 & 52 & 15 & 29 \\
\hline $17 \mathrm{R}-1,25$ & 144.45 & 194 & 324 & 13 & 16 & 11 & 12 & 13 & 16 & 19 \\
\hline $18 \mathrm{R}-1,70$ & 154.40 & 66 & 494 & 79 & 35 & 24 & 37 & 50 & 54 & 69 \\
\hline $18 \mathrm{R}-1,121$ & 154.91 & 22 & 160 & 28 & 66 & 26 & 21 & 31 & 20 & 29 \\
\hline $19 \mathrm{R}-1,1$ & 162.91 & 44 & 568 & 38 & 34 & 14 & 59 & 25 & 32 & 45 \\
\hline $19 \mathrm{R}-1,37$ & 163.27 & 71 & 714 & 46 & 37 & 18 & 81 & 43 & 56 & 76 \\
\hline $21 \mathrm{R}-1,54$ Gray & 181.84 & 116 & 354 & 87 & 66 & 21 & 83 & 70 & 118 & 118 \\
\hline 21R-1, 56 White & 181.86 & 189 & 258 & 15 & 69 & 14 & 16 & 21 & 78 & 20 \\
\hline $21 \mathrm{R}-2,8$ & 182.88 & 204 & 199 & 8 & 22 & 10 & 6 & 7 & 20 & 8 \\
\hline $22 \mathrm{R}-1,19$ & 191.19 & 542 & 522 & 80 & 114 & 28 & 42 & 82 & 103 & 118 \\
\hline $22 \mathrm{R}-1,30$ & 210.20 & 57 & 82 & 26 & 46 & 19 & 29 & 29 & 55 & 48 \\
\hline $26 \mathrm{R}-1,4$ & 228.64 & 743 & 76 & 127 & 56 & 30 & 105 & 105 & 72 & 115 \\
\hline $26 \mathrm{R}-1,106$ & 229.66 & 609 & 206 & 202 & 124 & 43 & 125 & 399 & 86 & 112 \\
\hline $26 \mathrm{R}-2,12$ & 230.22 & 267 & 120 & 229 & 109 & 64 & 113 & 407 & 101 & 125 \\
\hline $27 \mathrm{R}-1,30$ & 238.30 & 407 & 98 & 206 & 499 & 35 & 80 & 667 & 96 & 181 \\
\hline $28 \mathrm{R}-1,82$ & 248.02 & 259 & 85 & 143 & 465 & 66 & 108 & 416 & 101 & 11 \\
\hline $28 \mathrm{R}-2,48$ & 49.18 & 738 & 79 & 121 & 88 & 26 & 62 & 113 & 56 & 76 \\
\hline $28 \mathrm{R}-4,2$ & 251.72 & 276 & 84 & 166 & 327 & 46 & 96 & 569 & 88 & 118 \\
\hline $29 \mathrm{R}-3,72$ & 50.22 & 63 & 37 & 41 & 30 & 17 & 52 & 28 & 28 & 37 \\
\hline $30 \mathrm{R}-2,25$ & 267.65 & 184 & 78 & 56 & 35 & 16 & 46 & 75 & 63 & 52 \\
\hline $\mathrm{R}-2,146$ & 0.46 & 287 & 86 & 199 & 194 & 41 & 46 & 555 & 68 & 135 \\
\hline $33 \mathrm{R}-7,63$ & 296.33 & 120 & 49 & 234 & 237 & 52 & 99 & 378 & 87 & 132 \\
\hline$R-2,98$ & 8.88 & 157 & 66 & 86 & 192 & 36 & 49 & 110 & 83 & 126 \\
\hline $36 \mathrm{R}-2,39$ & 317.79 & 131 & 34 & 158 & 143 & 35 & 107 & 293 & 80 & 114 \\
\hline$R-3,28$ & 19.18 & 128 & 33 & 129 & 290 & 47 & 88 & 225 & 89 & 86 \\
\hline 35R-CC, I & 328.02 & 108 & 67 & 161 & 386 & 41 & 49 & 780 & 94 & 141 \\
\hline $\mathrm{R}-1,12$ & 334.62 & 184 & 54 & 180 & 350 & 49 & 70 & 549 & 123 & 121 \\
\hline $38 \mathrm{R}-1,24$ & 334.74 & 271 & 214 & 60 & 395 & 54 & 551 & 325 & 99 & 125 \\
\hline $38 \mathrm{R}-1,29$ Nodule & 334.79 & 125 & 2526 & 66 & 1 & 19 & 853 & 46 & 33 & 11 \\
\hline $39 \mathrm{R}-2,111$ & 337.15 & 152 & 8 & 139 & 340 & 48 & 123 & 809 & 88 & 118 \\
\hline $41 \mathrm{R}-1,93$ & 363.43 & 139 & 15 & 122 & 287 & 60 & 33 & 629 & 91 & 104 \\
\hline $50 \mathrm{R}-1,59$ & 440.79 & 92 & 15 & 286 & 131 & 22 & 133 & 248 & 79 & 58 \\
\hline $51 \mathrm{R}-1,88$ & 450.48 & 74 & 116 & 34 & 48 & 25 & 120 & 36 & 78 & 71 \\
\hline 51R-1, 135 Clear & 450.95 & 68 & 97 & 33 & 40 & 15 & 132 & 46 & 89 & 73 \\
\hline 5IR-1, 136 Dark & 450.96 & 62 & 64 & 24 & 37 & 8 & 116 & 19 & 57 & 55 \\
\hline $52 \mathrm{R}-1,141$ & 460.21 & 105 & 682 & 36 & 62 & 21 & 110 & 21 & 81 & 58 \\
\hline $52 \mathrm{R}-2,86$ & 461.16 & 99 & 482 & 49 & 41 & 17 & 88 & 19 & 102 & 84 \\
\hline $52 \mathrm{R}-2,86$ Fissure & 461.20 & 50 & 556 & 10 & 19 & 11 & 27 & 7 & 19 & 14 \\
\hline $53 \mathrm{R}-1,117$ & 466.07 & 62 & 347 & 27 & 31 & 16 & 45 & 16 & 54 & 37 \\
\hline 53R-2, 25 Pink & 466.65 & 47 & 89 & 30 & 29 & 12 & 42 & 13 & 50 & 44 \\
\hline 53R-2, 27 Brown & 466.67 & 70 & 413 & 40 & 27 & 16 & 54 & 15 & 61 & 47 \\
\hline $55 \mathrm{R}-1,126$ & 480.36 & 49 & 329 & 28 & 23 & 13 & 45 & 14 & 47 & 42 \\
\hline
\end{tabular}

manganite phase. Further microprobe investigations will determine the sites of barium within the oxide structure or as barite.

\section{CONCLUSIONS}

Mineralogical and chemical investigations conducted on a large set of samples from both Sites 800 and 801 allow the main trends of the sedimentation of the Pigafetta Basin since the Middle Jurassic to be described and accurately defined with six major stages and events. At this stage of the study, it would be pretentious to declare all the mysteries and details of these sediments resolved. The results are good preliminary data for further work with two different objectives: (1) on a small scale, to determine the complex seawater-rock interactions and the conditions of formation of the specific minerals found in the deposits (i.e., apatite, manganite, celadonite, and zeolites) and thus to specify the environments of deposition and of the conditions of subsequent diagenesis (see also Behl and Smith, and France-Lanord et al., both this volume), and (2) on a large scale, to compare this complete sequence with those deposited at the same time elsewhere in the mega-Pacific, and thus to relate the plate motion and subsidence story (see Larson and Lancelot, this volume). 
Table 10. Chemical composition of bulk samples of sediments and basement alteration products from Site 801: major elements (wt \%).

\begin{tabular}{|c|c|c|c|c|c|c|c|c|c|c|c|c|c|}
\hline $\begin{array}{l}\text { Sample } \\
\text { (cm, top) }\end{array}$ & $\begin{array}{l}\text { Depth } \\
\text { (mbsf) }\end{array}$ & $\mathrm{SiO}_{2}$ & $\mathrm{Al}_{2} \mathrm{O}_{3}$ & $\mathrm{MgO}$ & $\mathrm{CaO}$ & $\mathrm{Fe}_{2} \mathrm{O}_{3}$ & $\mathrm{Mn}_{3} \mathrm{O}_{4}$ & $\mathrm{TiO}_{2}$ & $\mathrm{Na}_{2} \mathrm{O}$ & $\mathrm{K}_{2} \mathrm{O}$ & $\mathrm{P}_{2} \mathrm{O}_{5}$ & LOI & Total \\
\hline \multicolumn{14}{|l|}{$129-801 \mathrm{~A}-$} \\
\hline $1 \mathrm{R}-1.40$ & 8.40 & 48.3 & 16.0 & 2.79 & 1.7 & 8.7 & 1.520 & 0.86 & 4.67 & 3.31 & 0.63 & 10.10 & 98.6 \\
\hline $3 R-1,63$ & 21.03 & 47.9 & 14.8 & 3.08 & 2.4 & 8.2 & 2.860 & 0.55 & 3.98 & 3.68 & 1.07 & 10.20 & 98.7 \\
\hline $3 \mathrm{R}-2,145$ & 23.35 & 49.3 & 16.1 & 3.24 & 1.9 & 7.2 & 2.100 & 0.54 & 3.21 & 3.91 & 0.92 & 9.71 & 98.1 \\
\hline $5 \mathrm{R}-1,13$ & 39.73 & 50.7 & 14.7 & 3.17 & 3.3 & 6.3 & 1.720 & 0.53 & 3.12 & 4.51 & 1.66 & 8.86 & 98.6 \\
\hline $5 \mathrm{R}-1,15$ & 39.75 & 9.4 & 2.4 & 0.76 & 45.4 & 1.2 & 0.145 & 0.14 & 0.38 & 0.02 & 0.29 & 39.09 & 99.2 \\
\hline $5 \mathrm{R}-1,62$ & 40.22 & 8.2 & 2.1 & 0.70 & 46.9 & 1.0 & 0.119 & 0.12 & 0.28 & 0.02 & 0.28 & 39.72 & 99.4 \\
\hline $5 \mathrm{R}-1,63$ & 40.23 & 51.6 & 14.0 & 3.11 & 3.4 & 6.0 & 1.490 & 0.50 & 3.09 & 4.24 & 1.31 & 9.68 & 98.4 \\
\hline $7 \mathrm{R}-1,67$ & 59.67 & 57.2 & 15.1 & 3.35 & 1.4 & 6.1 & 0.770 & 0.51 & 2.98 & 3.94 & 0.70 & 8.32 & 100.4 \\
\hline 7R-CC, 1 & 63.96 & 90.8 & 1.9 & 0.53 & 0.5 & 1.1 & 0.135 & 0.10 & 0.42 & 0.49 & 0.18 & 2.50 & 98.7 \\
\hline $10 \mathrm{R}-1,11$ & 87.61 & 90.5 & 2.1 & 0.54 & 0.3 & 1.2 & 0.118 & 0.16 & 0.55 & 0.51 & 0.13 & 2.68 & 98.8 \\
\hline $16 \mathrm{R}-1,4$ & 145.64 & 53.6 & 9.1 & 6.01 & 5.6 & 9.4 & 0.128 & 2.12 & 2.77 & 2.58 & 0.37 & 8.38 & 100.1 \\
\hline $16 \mathrm{R}-1,140$ & 147.00 & 52.6 & 10.1 & 9.55 & 6.1 & 10.7 & 0.175 & 2.24 & 2.14 & 0.61 & 0.43 & 6.28 & 100.9 \\
\hline 19R-1, 55 & 175.25 & 59.3 & 8.2 & 4.57 & 5.1 & 7.9 & 0.121 & 1.45 & 2.46 & 2.64 & 0.27 & 9.03 & 101.0 \\
\hline $19 \mathrm{R}-1,70$ & 175.35 & 74.9 & 5.7 & 2.86 & 2.6 & 5.1 & 0.082 & 1.04 & 1.66 & 1.66 & 0.24 & 5.28 & 101.1 \\
\hline \multicolumn{14}{|l|}{ 129-801B- } \\
\hline $2 \mathrm{R}-1,41$ & 203.91 & 50.2 & 10.0 & 11.60 & 5.4 & 11.0 & 0.125 & 2.12 & 3.66 & 0.71 & 0.33 & 5.05 & 100.2 \\
\hline $3 R-1,100$ & 213.90 & 51.3 & 9.5 & 12.90 & 2.7 & 10.3 & 0.160 & 1.54 & 2.89 & 1.83 & 0.41 & 6.51 & 100.0 \\
\hline $5 \mathrm{R}-1,50$ Green & 232.20 & 67.8 & 6.0 & 5.41 & 3.1 & 6.0 & 0.097 & 1.11 & 2.12 & 1.60 & 0.26 & 5.64 & 99.1 \\
\hline 5R-1, 52 Brown & 232.22 & 56.0 & 9.2 & 7.16 & 4.3 & 8.5 & 0.189 & 2.86 & 3.45 & 1.67 & 0.32 & 7.33 & 101.0 \\
\hline $5 \mathrm{R}-2,84$ & 234.04 & 50.0 & 9.1 & 10.60 & 5.0 & 10.5 & 0.189 & 2.11 & 2.53 & 2.55 & 0.44 & 7.12 & 100.1 \\
\hline $6 \mathrm{R}-4,62$ & 246.42 & 57.0 & 8.7 & 7.14 & 3.4 & 9.7 & 0.150 & 1.71 & 1.91 & 4.11 & 0.35 & 6.94 & 101.1 \\
\hline $7 \mathrm{R}-1,34$ & 251.34 & 50.9 & 8.4 & 7.87 & 5.7 & 10.1 & 0.241 & 1.69 & 2.19 & 3.77 & 0.26 & 9.44 & 100.6 \\
\hline $8 \mathrm{R}-1,130$ & 262.00 & 55.7 & 9.5 & 7.52 & 1.6 & 11.1 & 0.192 & 1.98 & 2.58 & 2.67 & 0.34 & 6.92 & 100.1 \\
\hline $8 R-5,102$ & 267.72 & 63.0 & 9.7 & 3.50 & 1.7 & 5.7 & 0.122 & 1.14 & 2.48 & 3.10 & 0.39 & 7.53 & 98.4 \\
\hline $14 \mathrm{R}-1,24$ Gray & 318.54 & 82.5 & 4.8 & 1.42 & 0.6 & 3.4 & 0.561 & 0.30 & 1.19 & 1.36 & 0.05 & 4.51 & 100.7 \\
\hline 14R-1, 25 Pink & 318.55 & 84.1 & 3.9 & 1.19 & 0.6 & 2.7 & 0.228 & 0.22 & 1.04 & 1.15 & 0.05 & 4.05 & 99.2 \\
\hline $18 \mathrm{R}-1,24$ & 356.04 & 85.4 & 3.7 & 0.90 & 0.5 & 2.4 & 0.303 & 0.21 & 0.80 & 1.15 & 0.12 & 3.77 & 99.3 \\
\hline $24 \mathrm{R}-1,54$ & 401.14 & 85.3 & 3.2 & 0.97 & 0.4 & 2.7 & 0.528 & 0.17 & 0.80 & 0.94 & 0.05 & 3.21 & 98.3 \\
\hline $25 \mathrm{R}-1,1$ & 405.21 & 85.9 & 3.4 & 0.88 & 0.6 & 2.8 & 0.428 & 0.21 & 0.88 & 0.99 & 0.05 & 3.72 & 99.9 \\
\hline $27 \mathrm{R}-1,30$ & 415.00 & 96.8 & 0.3 & 0.06 & 0.3 & 0.5 & 0.110 & 0.05 & 0.19 & 0.13 & 0.05 & 1.60 & 100.1 \\
\hline $33 \mathrm{R}-1,43$ & 443.23 & 81.4 & 4.5 & 1.11 & 0.5 & 5.7 & 0.040 & 0.31 & 0.88 & 1.63 & 0.05 & 4.01 & 100.1 \\
\hline $33 \mathrm{R}-2,48$ & 444.78 & 83.7 & 3.0 & 0.77 & 0.4 & 5.4 & 0.039 & 0.20 & 0.68 & 1.22 & 0.05 & 3.55 & 99.0 \\
\hline $35 R-2,120$ & 455.00 & 56.3 & 11.3 & 2.84 & 1.4 & 15.3 & 0.402 & 0.85 & 1.43 & 3.67 & 0.21 & 6.85 & 100.6 \\
\hline $35 R-2,140$ & 455.20 & 64.8 & 8.3 & 1.96 & 0.8 & 13.3 & 0.157 & 0.56 & 1.41 & 2.78 & 0.22 & 6.17 & 100.5 \\
\hline 35R-3, 1 Red & 455.31 & 66.7 & 8.4 & 2.14 & 0.7 & 11.1 & 0.149 & 0.59 & 1.37 & 3.06 & 0.17 & 5.83 & 100.2 \\
\hline 35R-3, 3 Yellow & 455.33 & 67.0 & 6.3 & 1.63 & 0.6 & 12.7 & 0.149 & 0.39 & 1.13 & 2.38 & 0.26 & 5.70 & 98.2 \\
\hline $35 \mathrm{R}-3,19$ & 455.49 & 69.8 & 7.8 & 1.76 & 0.6 & 9.8 & 0.070 & 0.54 & 1.13 & 2.70 & 0.10 & 5.19 & 99.5 \\
\hline 44R-1, 125 Brown & 502.95 & 75.6 & 0.3 & 0.76 & 10.5 & 1.0 & 0.524 & 0.06 & 0.07 & 0.02 & 0.05 & 10.37 & 99.3 \\
\hline $44 \mathrm{R}-1,126$ Green & 502.96 & 2.1 & 0.3 & 14.10 & 31.5 & 6.5 & 1.040 & 0.05 & 0.11 & 0.02 & 0.05 & 43.16 & 98.9 \\
\hline $44 \mathrm{R}-1,132$ & 503.03 & 85.9 & 0.9 & 1.07 & 3.3 & 2.9 & 0.181 & 0.10 & 0.09 & 0.38 & 0.05 & 4.49 & 99.4 \\
\hline \multicolumn{14}{|l|}{$129-801 \mathrm{C}$ - } \\
\hline $4 \mathrm{R}-1.73$ & 522.43 & 83.8 & 0.2 & 0.09 & 0.2 & 14.0 & 0.016 & 0.02 & 0.08 & 0.06 & 0.20 & 2.36 & 101.0 \\
\hline $4 \mathrm{R}-2,101$ & 524.08 & 95.4 & 0.2 & 0.08 & 0.2 & 2.4 & 0.010 & 0.02 & 0.10 & 0.23 & 0.17 & 0.74 & 99.6 \\
\hline 4R-2, 102 White & 524.09 & 94.1 & 0.2 & 0.11 & 1.8 & 1.9 & 0.010 & 0.02 & 0.12 & 0.28 & 0.99 & 0.51 & 100.0 \\
\hline SR-2, 99 Green & 533.45 & 40.6 & 5.4 & 4.97 & 1.7 & 32.5 & 0.130 & 0.10 & 0.70 & 4.45 & 0.22 & 9.93 & 100.7 \\
\hline SR-5, 124 Green & 537.93 & 41.4 & 1.9 & 4.20 & 11.3 & 19.9 & 0.295 & 0.02 & 0.34 & 5.63 & 0.05 & 15.40 & 100.4 \\
\hline $7 \mathrm{R}-3,120$ & 554.18 & 90.4 & 0.1 & 0.25 & 2.8 & 2.6 & 0.063 & 0.02 & 0.02 & 0.24 & 0.05 & 3.21 & 99.8 \\
\hline $8 \mathrm{R}-1,23$ & 559.73 & 44.0 & 4.7 & 4.87 & 1.5 & 25.4 & 0.286 & 0.22 & 0.71 & 4.01 & 0.13 & 12.72 & 98.5 \\
\hline $9 \mathrm{R}-2,97$ & 565.57 & 50.2 & 14.2 & 6.77 & 12.1 & 11.6 & 0.190 & 1.40 & 2.59 & 0.02 & 0.20 & 1.13 & 100.4 \\
\hline
\end{tabular}

The hydrothermal alteration of the upper crustal sequence, during the latest stages of the setting of upper tholeiitic lava flows, pillows, and alkali lava flows, is fairly comparable to that of the Cyprus and Oman ophiolites. Peculiarly, the siliceous and ferruginous hydrothermal deposit, with scarce apatite, is similar to the Cyprus hydrothermal ochre.

The basal Callovian-Bathonian red sediments (stage 1) are identical to the commonly observed metalliferous deposits found as a layer between the basement and the overlying true pelagic sediments in oceanic basins. Biogenic siliceous tests are mixed with the iron supply from the hydrothermal activity of the nearby ridge crest (oxidation of hydrothermal metallic ores, alteration of basalts). The Pigafetta Basin basal red radiolarite is like the basal red radiolarites found over Tethyan ophiolites (i.e., Oman, Apennines). Without secondary tectonic metamorphism, their "simple" two phases, $\mathrm{Si}$ and $\mathrm{Fe}$, both relate to the variability of the episodic inputs. A ridge crest oxic environment also seems more favorable for the preservation of the primary biogenic markers as $\mathrm{Ba}$ and $\mathrm{Sr}$ during early diagenetic processes.

Mesozoic sedimentation in the open Pacific Ocean was dominated by siliceous biomineralization, making it significantly different from the Atlantic realm (stages 2, 4, and 5). The supply of biogenic phases is a function of productivity, and the siliceous trend follows the paleolatitudinal migration of the sites. The heaviest biogenic ( $\mathrm{Si}$ and Ca) contribution to sedimentation occurred during the AlbianCenomanian at Site 800 when it was at a subequatorial location.

The middle Cretaceous event (stage 3 ) is well recorded in both sedimentary sequences. A "mineral stratigraphy" related to the type of the redeposited volcaniclastic facies (as a function of the proximity to the volcanic source) allows the upper part of the section at Site 800 and the lower part of that at Site 801 to be correlated. Thus, the sites 
Table 11. Chemical composition of bulk samples of sediments and basement alteration products from Site 801: trace elements (ppm).

\begin{tabular}{|c|c|c|c|c|c|c|c|c|c|c|}
\hline $\begin{array}{c}\text { Sample } \\
(\mathrm{cm}, \text { top })\end{array}$ & $\begin{array}{l}\text { Depth } \\
\text { (mbsf) }\end{array}$ & $\mathrm{Sr}$ & $\mathrm{Ba}$ & V & $\mathrm{Ni}$ & Co & $\mathrm{Cu}$ & $\mathrm{Cr}$ & $\mathrm{Zn}$ & $\mathrm{Zr}$ \\
\hline \multicolumn{11}{|l|}{$128-801 \mathrm{~A}-$} \\
\hline IR-1, 40 & 8.40 & 196 & 267 & 155 & 228 & 176 & 308 & 70 & 132 & 182 \\
\hline $3 R-1,63$ & 21.03 & 227 & 347 & 131 & 414 & 244 & 342 & 50 & 148 & 179 \\
\hline $3 R-2,145$ & 23.35 & 171 & 371 & 121 & 433 & 202 & 429 & 60 & 190 & 162 \\
\hline $5 \mathrm{R}-1,13$ & 39.73 & 195 & 318 & 102 & 399 & 162 & 341 & 43 & 172 & 157 \\
\hline $5 \mathrm{R}-1,15$ & 39.75 & 856 & 55 & 18 & 46 & 8 & 64 & 8 & 35 & 32 \\
\hline $5 R-1,62$ & 40.22 & 888 & 50 & 15 & 45 & 6 & 54 & 7 & 23 & 28 \\
\hline $5 R-1,63$ & 40.23 & 203 & 342 & 92 & 317 & 138 & 299 & 39 & 156 & 145 \\
\hline $7 R-1,67$ & 59.67 & 176 & 280 & 92 & 147 & 52 & 308 & 44 & 159 & 135 \\
\hline 7R-CC. 1 & 63.96 & 28 & 43 & 14 & 34 & 11 & 77 & 12 & 16 & 23 \\
\hline $10 \mathrm{R}-1,11$ & 87.61 & 26 & 100 & 18 & 23 & 11 & 42 & 9 & 32 & 14 \\
\hline $16 \mathrm{R}-1,4$ & 145.64 & 413 & 260 & 181 & 121 & 34 & 73 & 312 & 125 & 215 \\
\hline $16 \mathrm{R}-1,140$ & 147.00 & 227 & 70 & 233 & 137 & 39 & 92 & 567 & 99 & 187 \\
\hline $19 \mathrm{R}-1,55$ & 175.25 & 336 & 226 & 129 & 78 & 26 & 78 & 199 & 79 & 152 \\
\hline $19 \mathrm{R}-1,70$ & 175.35 & 187 & 158 & 81 & 63 & 28 & 57 & 136 & 63 & 109 \\
\hline \multicolumn{11}{|l|}{ 129-801B- } \\
\hline $2 \mathrm{R}-1,41$ & 203.91 & 199 & 195 & 203 & 292 & 44 & 63 & 671 & 108 & 191 \\
\hline $3 R-1,100$ & 213.90 & 194 & 107 & 135 & 271 & 47 & 80 & 346 & 103 & 159 \\
\hline $5 R-1,50$ Green & 232.20 & 297 & 41 & 111 & 128 & 37 & 49 & 244 & 62 & 116 \\
\hline 5R-1, 52 Brown & 232.22 & 647 & 111 & 244 & 151 & 42 & 96 & 725 & 121 & 240 \\
\hline $5 R-2,84$ & 234.04 & 216 & 81 & 180 & 311 & 53 & 96 & 576 & 99 & 204 \\
\hline $6 R-4,62$ & 246.42 & 148 & 116 & 203 & 151 & 39 & 80 & 332 & 74 & 166 \\
\hline $7 \mathrm{R}-1,34$ & 251.34 & 269 & 189 & 169 & 186 & 42 & 94 & 432 & 84 & 157 \\
\hline $8 \mathrm{R}-1,130$ & 262.00 & 228 & 155 & 170 & 172 & 45 & 160 & 250 & 166 & 199 \\
\hline $8 \mathrm{R}-5,102$ & 267.72 & 494 & 223 & 234 & 114 & 44 & 129 & 173 & 76 & 135 \\
\hline 14R-1, 24 Gray & 318.54 & 82 & 236 & 29 & 46 & 12 & 62 & 11 & 78 & 68 \\
\hline 14R-1, 25 Pink & 318.55 & 58 & 142 & 32 & 29 & 8 & 46 & 12 & 106 & 58 \\
\hline $18 \mathrm{R}-1,24$ & 356.04 & 56 & 1059 & 35 & 30 & 10 & 64 & 16 & 51 & 53 \\
\hline $24 \mathrm{R}-1,54$ & 401.14 & 78 & 2629 & 33 & 29 & 10 & 73 & 14 & 47 & 46 \\
\hline $25 \mathrm{R}-1,1$ & 405.21 & 72 & 1544 & 34 & 18 & 8 & 69 & 8 & 66 & 49 \\
\hline $27 \mathrm{R}-1,30$ & 415.00 & 11 & 88 & 7 & 1 & 5 & 32 & 1 & 4 & 10 \\
\hline $33 \mathrm{R}-1,43$ & 443.23 & 75 & 1849 & 81 & 29 & 11 & 59 & 20 & 66 & 86 \\
\hline $33 R-2,48$ & 444.78 & 42 & 923 & 102 & 29 & 12 & 94 & 16 & 39 & 73 \\
\hline $35 \mathrm{R}-2,120$ & 455.00 & 108 & 1227 & 157 & 142 & 19 & 137 & 54 & 159 & 148 \\
\hline $35 R-2,140$ & 455.20 & 114 & 2560 & 172 & 82 & 24 & 119 & 39 & 124 & 155 \\
\hline $35 \mathrm{R}-3,1$ Red & 455.31 & 112 & 2449 & 146 & 76 & 15 & 87 & 43 & 109 & 140 \\
\hline 35R-3, 3 Yellow & 455.33 & 96 & 2297 & 210 & 85 & 22 & 128 & 32 & 137 & 140 \\
\hline $35 \mathrm{R}-3,19$ & 455.49 & 92 & 2036 & 125 & 60 & 15 & 62 & 13 & 104 & 112 \\
\hline 44R-1, 125 Brown & 502.95 & 40 & 17 & 16 & 10 & 7 & 11 & 7 & 7 & 31 \\
\hline 44R-1, 126 Green & 502.96 & 191 & 18 & 75 & 43 & 17 & 11 & 27 & 83 & 185 \\
\hline $44 \mathrm{R}-1,132$ & 503.03 & 33 & 28 & 33 & 34 & 8 & 1 & 5 & 18 & 44 \\
\hline \multicolumn{11}{|l|}{ 129-801C. } \\
\hline $4 \mathrm{R}-1,73$ & 522.43 & 1 & 1 & 81 & 26 & 14 & 15 & 6 & 14 & 11 \\
\hline $4 \mathrm{R}-2,101$ & 524.08 & 6 & 9 & 17 & 17 & 8 & 9 & 10 & 5 & 11 \\
\hline 4R-2, 102 White & 524.09 & 21 & 10 & 13 & 20 & 9 & 8 & 8 & 7 & 9 \\
\hline 5R-2, 99 Green & 533.45 & 37 & 5 & 412 & 148 & 21 & 48 & 151 & 130 & 50 \\
\hline 5R-5, 124 Green & 537.93 & 41 & 1 & 264 & 105 & 18 & 9 & 56 & 78 & 32 \\
\hline $7 \mathrm{R}-3,120$ & 554.18 & 7 & 1 & 24 & 5 & 5 & 5 & 3 & 1 & 6 \\
\hline $8 \mathrm{R}-1,23$ & 559.73 & 41 & 7 & 228 & 95 & 53 & 62 & 39 & 93 & 48 \\
\hline $9 R-2,97$ & 565.57 & 118 & 6 & 369 & 70 & 44 & 74 & 199 & 89 & 94 \\
\hline
\end{tabular}

successively occupied the same geological setting, at a relatively distal location from a fixed volcanic source (hotspot edifice[s]). The activity of the source was recorded from the early Aptian to Cenomanian by the deposits of the Pigafetta Basin, at the time when both sites were at their southernmost paleoposition.

Detrital and eolian terrigenous input began to be significant during the Late Cretaceous and early Cenozoic. The surficial, condensed red clay (stage 6) exhibits a "zeolite stratigraphy" with older clinoptilolite and recent phillipsite. This surface deep-sea clay has a higher detrital content than its central Pacific equivalent.

\section{ACKNOWLEDGMENTS}

This article is dedicated to the memory of Professor Georges Millot. I am grateful to Y. Lancelot, who gave me the opportunity to discover the "Old Pac" realm. Sincere thanks are due to the Leg 129 Scientific Party and the ODP Technical and Operations staff for the successful cruise. This article has benefited from the review and useful corrections of T. A. Davies, M. Underwood, and E. L. Winterer. I am indebted to A. Fisher for careful improvement to the English version of the manuscript. The analytical work was performed using facilities at Centre de Géochimie de la Surface (CNRS), Strasbourg. This study was supported by a INSU-IST Grant, 90/ATP/781/AP90803911-GEO307.

\section{REFERENCES}

Alt, J. C., Honnorez, J., Laverne C., and Emmermann, R., 1986. Hydrothermal alteration of a $1 \mathrm{~km}$ section through the upper oceanic crust, Deep Sea Drilling Project Hole 504B: mineralogy, chemistry and evolution of seawater-basalt interactions. J. Geophys. Res., 91:10309-10335. 
Arrhenius, G. O., and Bonatti, E., 1965. Neptunism and vulcanism in the ocean. Progress Oceanogr., 3:7-22.

Baker, P. A., Gieskes, J. M., and Elderfield, H., 1982. Diagenesis of carbonate in deep-sea sediments: evidence from $\mathrm{Sr} / \mathrm{Ca}$ ratios and interstitial dissolved $\mathrm{Sr}^{2+}$ data. J. Sediment. Petrol., 52:71-82.

Besnus, Y., and Rouault, R., 1973. Une méthode d'analyse de roches au spectromètre d'arc à lecture directe par un dispositif d'électrode rotative. Analusis, 2:111-116.

Bohkle, J. K., Alt, J. C., and Muehlenbachs, K., 1984. Oxygen isotope-water relations in altered deep-sea basalts: low temperature mineralogical controls. Can. J. Earth Sci., 21:67-77.

Bonatti, E., 1981. Metal deposits in the oceanic lithosphere. In Emiliani, C. (Ed.), The Sea (Vol. 7): New York (Wiley), 639-686.

Bonatti, E., Kraemer, T., and Rydell, H. S., 1972. Classification and genesis of submarine iron-manganese deposits. In Horn, D. R. (Ed.), Ferromanganese Deposits on the Ocean Floor. Natl. Sci. Found., 149-16.

Boström, K., 1970. Submarine volcanism as a source of iron. Earth Planet. Sci. Lett., 9:348-354.

1983. Genesis of ferromanganese deposits - diagnostic criteria for recent and old deposits. In Rona, P. A., et al. (Eds.), Hydrothermal Processes at Seafloor Spreading Centers. NATO Conf. Ser. IV, 12:473-489.

Bryant, W. R., and Bennett, R. H., 1988. Origin, physical and mineralogical nature of red clays: the Pacific ocean as a model. Geo-Mar. Lett., 8:189-249.

Buatier, M., Honnorez, J., and Ehret, G., 1989. Fe-smectite-glauconite transition in hydrothermal clays from Galapagos Spreading Center. Clays Clay Min., 37:532-541.

Church, T. M., 1979. Marine barite. In Burns, R. G. (Ed.), Marine Minerals. Mineral. Soc. Am., Short Courses, 6:175-210.

Clauer, N., Hoffert, M., and Karpoff, A. M., 1982. The Rb-Sr isotope system as an index of origin and diagenetic evolution of southern Pacific red clays. Geochim. Cosmochim. Acta, 46:2659-2664.

Cole, T. G., 1985. Composition, oxygen isotope geochemistry, and origin of smectite in metalliferous sediments of Bauer Deep, southeast Pacific. Geochim. Cosmochim. Acta, 49:221-235.

Crovisier, J. L., Honnorez, J., and Eberhart, J. P., 1987. Dissolution of basaltic glass in seawater: mechanism and rate. Geochim. Cosmochim. Acta, 47:377-387.

Duplay, J., Paquet, H., Kossovskaya, A., and Tardy, Y., 1989. Estimation de la température de formation des paragenèses saponite-céladonite et glauconite-nontronite dans les altérations sous-marines de basaltes, par la méthode des corrélations entre éléments au sein de populations monominérales. C. R. Acad. Sci. Ser. 2, 309:53-58.

Dymond, J., Corliss, J. B., Heath, G. R., Field, C. W., Dasch, E. J., and Veeh, H. H., 1973. Origin of metalliferous sediments from the Pacific Ocean. Geol. Soc. Am. Bull., 84:3355-3372.

Eberhart, J. P., 1989. Analyse structurale et chimique des matériaux: Paris (Dunod Ed.).

Froelich, P. N., Bender, M. L., and Heath, G. R., 1977. Phosphorus accumulation rates in metalliferous sediments on the East Pacific Rise. Earth Planet. Sci. Lett., 34:351-359.

Garrison, R. E., 1981. Diagenesis of oceanic sediments: a review of the DSDP perspectives. In Warme, J. E., Douglas, R. G., and Winterer, E. L. (Eds.), The Deep Sea Drilling Project: A Decade of Progress. Spec. Publ.-Soc. Econ. Paleontol. Mineral., 32:181-207.

Goldberg, E. D., and Arrhenius, G., 1958. Chemistry of the Pacific pelagic sediments. Geochim. Cosmochim. Acta, 48:2469-2482.

Graham, D. W., Bender, M. L., Williams, D. F., and Keigwin, L. D., Jr., 1982. Strontium-calcium ratios in Cenozoic planktonic foraminifera. Geochim. Cosmochim. Acta, 46:1281-1292.

Heath, G. R., Burckle, L. H., et al., 1985. Init. Repts. DSDP, 86: Washington (U.S. Govt. Printing Office).

Heezen, B. C., MacGregor, I. D., et al., 1973. Init. Repts. DSDP, 20: Washington (U.S. Govt. Printing Office).

Hoffert, M., Karpoff, A. M., Clauer, N., Schaaf, A., Courtois, C., and Pautot, G., 1978. Néoformations et altérations dans trois faciès volcanosédimentaires du Pacifique Sud. Oceanol. Acta, 1:187-202.

Honnorez, J., Karpoff, A. M., and Trauth-Badaut, D., 1983. Sedimentology, mineralogy and geochemistry of green clays samples from Galapagos Hydrothermal mounds, Holes 506, 506C and 507D, Deep Sea Drilling Project, Leg 70. In Honnorez, J., Von Herzen, R. P., et al., Init. Repts. DSDP, 70: Washington (U.S. Govt. Printing Office), 225-233.

Karpoff, A. M., 1980. The sedimentary deposits of Suiko seamount (Leg 55, Site 433 ): from the reef environment to the pelagic sedimentation. In
Jackson, E. D., Koizumi, I., et al., Init. Repts. DSDP, 55: Washington (U.S. Govt. Printing Office), 491-501.

1989. Les facies pélagiques condensés Cénozoiques des océans Pacifique et Atlantique: témoins des grandes crises géodynamiques [Thèse Doc. Sci.]. Univ. Louis Pasteur, Strasbourg.

Karpoff, A. M., Bourbon, M., Ancel, B., and de Graciansky, P. C., 1985. Diagenetic polymetallic crusts at Sites 550 and 548 of Leg 80, northeastern Atlantic ocean. In de Graciansky, P. C., Poag, C. W., et al., Init. Repts. DSDP, 80: Washington (U.S. Govt. Printing Office), 823-844.

Karpoff, A. M., Hoffert, M., and Clauer, N., 1981. Sedimentary sequences at Sites 464: silicification processes and transition between siliceous biogenic oozes and brown clays. In Thiede, J., Vallier, T. L., et al., Init. Repts. DSDP. 62: Washington (U.S. Govt. Print. Office), 579-571.

Karpoff, A. M., Peterschmitt, I., and Hoffert, M., 1980. Mineralogy and geochemistry of sedimentary deposits on Emperor Seamounts, Site 430, 431 432: authigenesis of silicates, phosphates and ferromanganese oxides. In Jackson, E. D., Koizumi, I., et al., Init. Repts. DSDP, 55: Washington (U.S. Govt. Printing Office), 463-489.

Karpoff, A. M., Walter, A.-V., and Pflumio, C., 1988. Metalliferous sediments within lava sequences of the Sumail ophiolite (Oman): mineralogical and geochemical characterization, origin and evolution. Tectonophysics, 151:223-245.

Kastner, M., 1979. Zeolites. In Burns, R. G. (Ed.), Marine Minerals. Mineral. Soc. Am., Short Courses, 6:99-122.

1981. Authigenic silicates in deep-sea sediments: formation and diagenesis. In Emiliani, C. (Ed.), The Sea (Vol. 7): New York (Wiley), 915-980.

Keller, W. D., Reynolds, R. C., and Inoue, A., 1986. Morphology of clay minerals in the smectite-to-illite conversion series by scanning electron microscopy. Clays Clay Min., 34:187-197.

Kennett, J. P., 1982. Marine Geology: Englewood Cliffs, NJ (Prentice Hall).

Kent, D. V., and Gradstein, F. M., 1985. A Cretaceous and Jurassic geochronology. Geol. Soc. Am. Bull., 96:1419-1427.

Khoury, H. N., and Eberl, D. D., 1979. Bubble-wall shards altered to montmorillonite. Clays Clay Min., 27:291-292.

Kolodny, Y., 1981. Phosphorites. In Emiliani, C. (Ed.), The Sea (Vol. 7): New York (Wiley), 981-1024.

Konta, J., 1986. Textural and composition of bentonite derived from volcanic ash. Clays Clay Min., 34:257-265.

Kurnosov, V. B., Chudaev, O. V., and Shevchenko, A. Y., 1983. Mineralogy and geochemistry of sediments from Galapagos Hydrothermal mounds, Leg 70, Deep Sea Drilling Project. In Honnorez, J., Von Herzen, R. P., et al., Init. Repts. DSDP, 70: Washington (U.S. Govt. Printing Office), 225-233.

Lancelot, Y., Larson, R. L., et al., 1990. Proc. ODP., Init. Repts., 129: College Station, TX (Ocean Drilling Program).

Larson, R. L., Moberly, R., et al., 1975. Init. Repts. DSDP, 32: Washington (U.S. Govt. Printing Office).

Lenotre, N., Chamley, H., and Hoffert, M., 1985. Clay stratigraphy at Deep Sea Drilling Project Sites 576 and 578, Leg 86 (Western North Pacific). In Heath, G. R., Burckle, L. H., et al., Init. Repts. DSDP, 86: Washington (U.S. Govt. Printing Office), 571-579.

Manghnani, M. H., Schlanger, S. O., and Milholland, P. D., 1980. Elastic properties related to depth of burial, strontium content and age, and diagenetic stage in pelagic carbonates sediments. In Kuperman, W. A., and Jensen, F. B. (Eds.), Bottom-Interacting Ocean Acoustics: New York (Plenum), 41-51.

McKenzie, J. A., Isern, A., Karpoff, A. M., and Swart, P. K., 1990. Basal dolomitic sediments, Tyrrhenian Sea, Ocean Drilling Program, Leg 107. In Kastens, K. A., Mascle, J., et al., Proc. ODP., Sci. Results, 107: College Station, TX (Ocean Drilling Program), 141-152.

McMurtry, G. M., and Yeh, H.-W., 1981. Hydrothermal clay mineral formation of the East Pacific Rise and Bauer Basin sediments. Chem. Geol., $32: 189-205$

Palmer, A. R., 1983. The decade of North American geology: 1983 geological time scale. Geology, 11:503-504.

Pisciotto, K. A., 1981. Distribution, thermal histories, isotopic composition, and refection characteristics of siliceous rocks recovered by the Deep Sea Drilling Project. In Warme, J. E., Douglas, R. G., and Winterer, E. L., et al. (Eds.), The Deep Sea Drilling Project: A Decade of Progress. Spec. Publ.-Soc. Econ. Paleontol. Mineral., 32:129-148.

Robertson, A.H.F., and Fleet, A. J., 1986. Geochemistry and palaeo-oceanography of metalliferous and pelagic sediments from the Late Cretaceous Oman ophiolite. Mar. Pet. Geol., 3:315-337. 
Samuel, J., Rouault, R., and Besnus, Y., 1985. Analyse multiélémentaire standardisée des matériaux géologiques en spectrométrie d'emission par plasma à couplage inductif. Analusis, 13:312-317.

Shipboard Scientific Party, 1990a. Site 800. In Lancelot, Y., Larson, R. L., et al., Proc. ODP, Init. Repts., 129: College Station, TX (Ocean Drilling Program), 33-89.

, 1990b. Site 801. In Lancelot, Y., Larson, R. L., et al., Proc. ODP., Init. Repts, 129: College Station, TX (Ocean Drilling Program), 91-170.

Thiede, J., Vallier, T. L., et al., 1981. Init. Repts. DSDP, 62: Washington (U.S. Govt. Printing Office).
Toth, J. R., 1980. Deposition of submarine crusts rich in manganese and iron. Geol. Soc. Am. Bull., 91:44-54.

Veizer, J., and Demovic, R., 1974. Sr as a tool of facies analysis. J. Sediment. Petrol., 44:93-115.

Date of initial receipt: 6 June 1991

Date of acceptance: 6 January 1992

Ms 129B-110

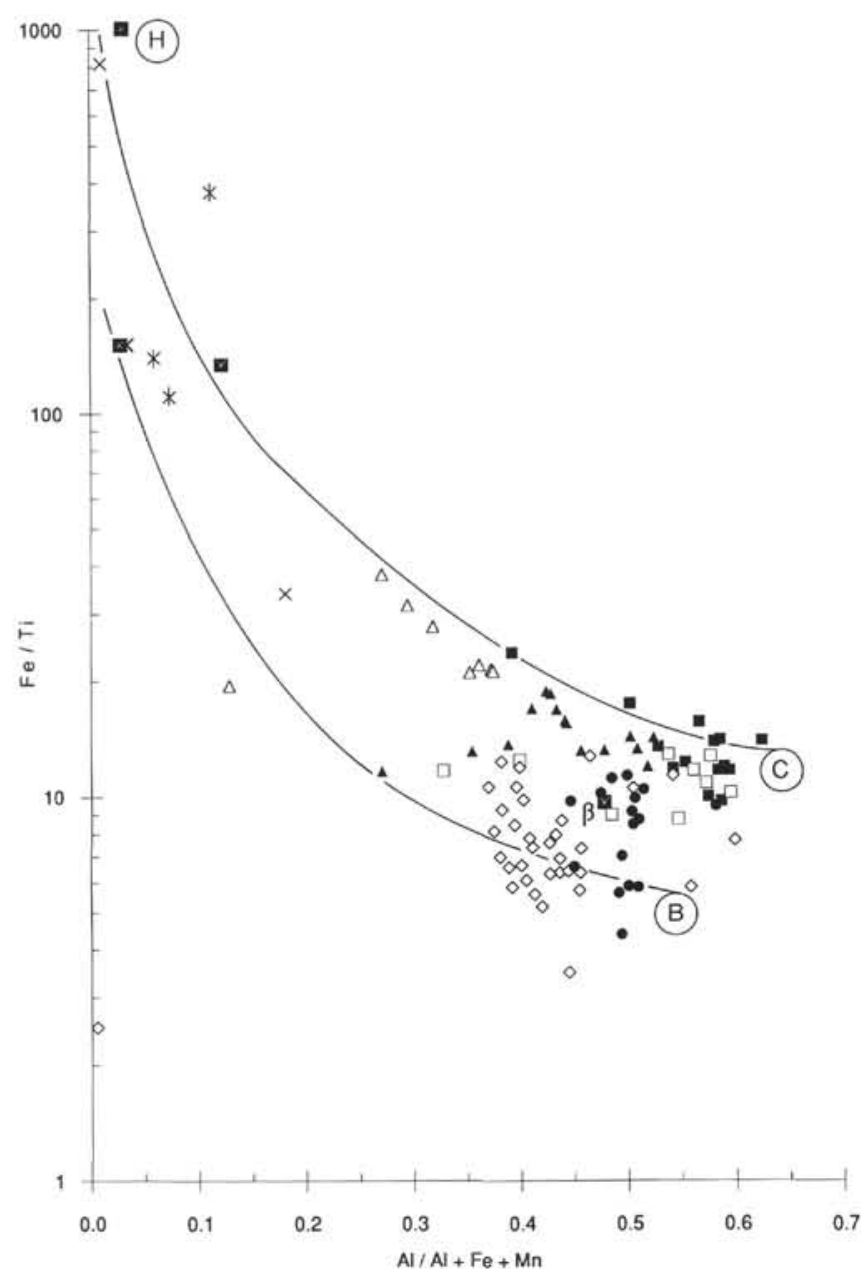

Figure 7. Relationship between $\mathrm{Al} / \mathrm{Al}+\mathrm{Fe}+\mathrm{Mn}$ and $\mathrm{Fe} / \mathrm{Ti}$ in lithologic facies from Sites 800 and 801 (after Boström, 1970, 1983). Ideal mixing curves: from hydrothermal and EPR deposits $(\mathrm{H})$ to mean value of continental crust or terrigenous material (C), and to mean value of oceanic crust or basalts (B). Same symbols as in Figure 6. 


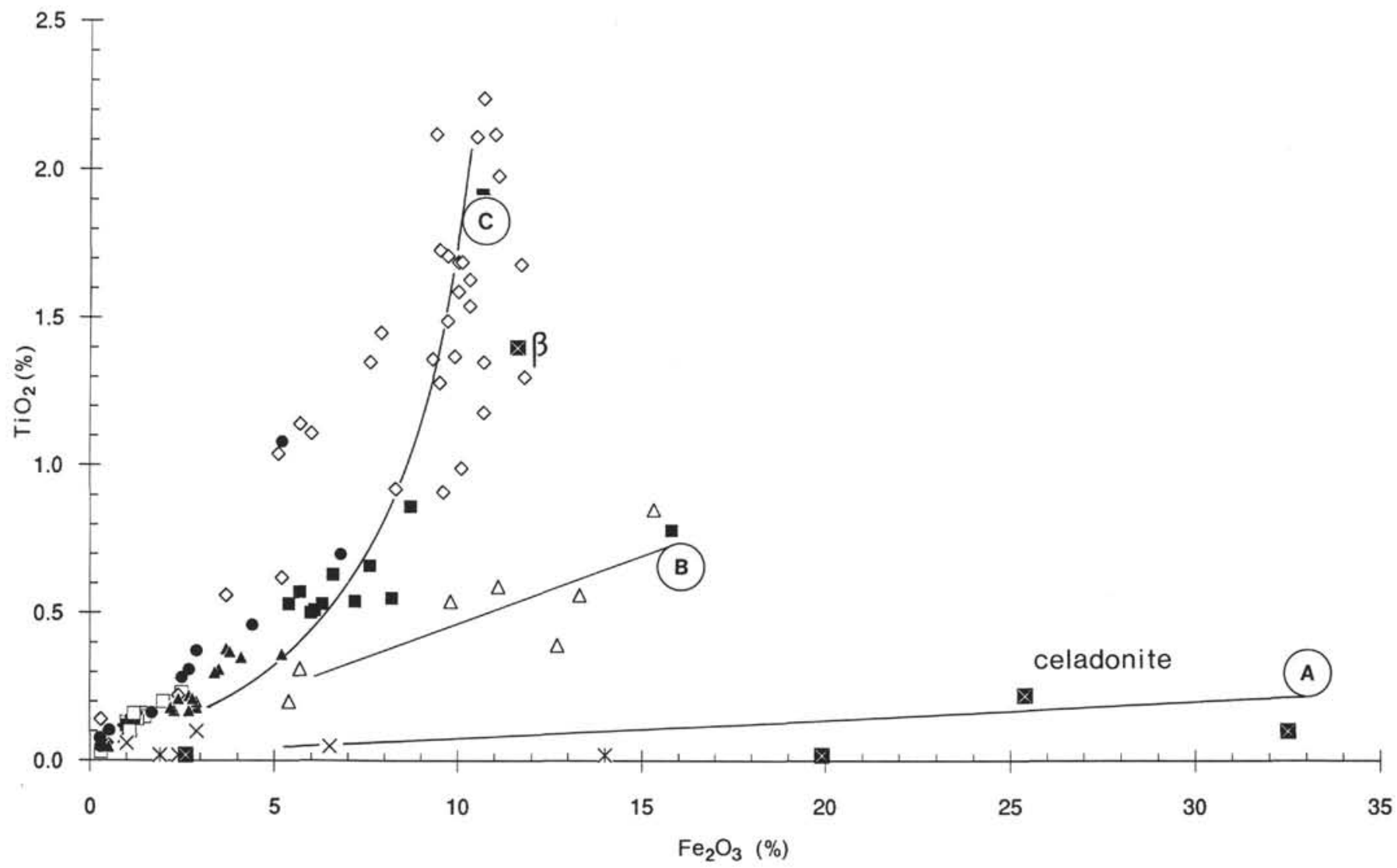

Figure 8. Relationship between Fe and Ti oxides contents in the sedimentary deposits from Sites 800 and 801 . A. Basaltic alteration trend (hydrothermalism). B. Basal red radiolarite trend. C. Volcaniclastic deposits and detrital trend (halmyrolysis). Same symbols as in Figure 6. 


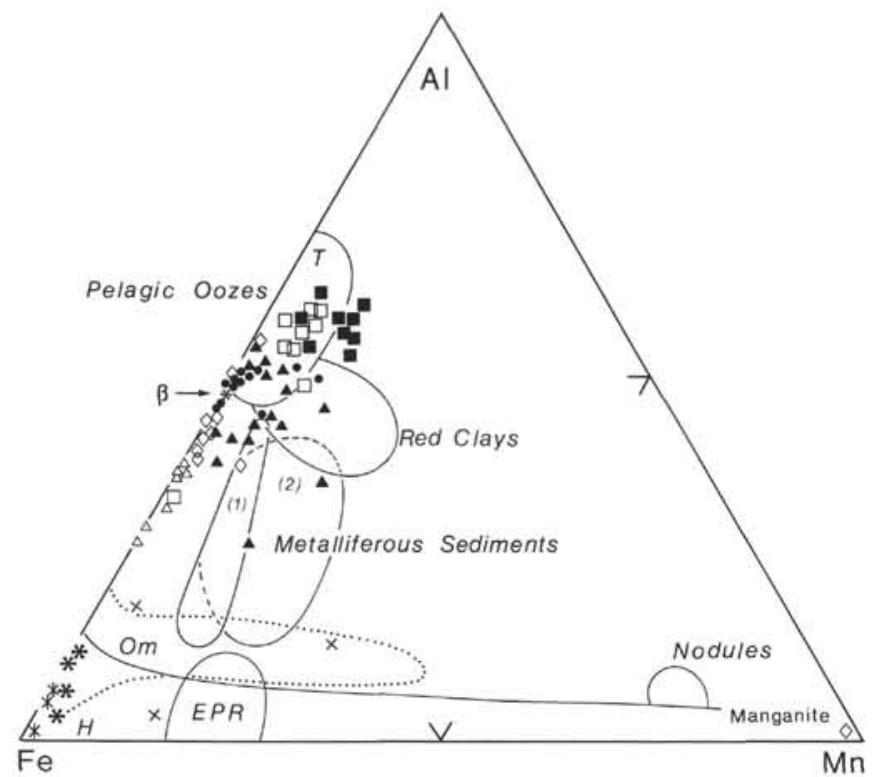

Figure 9. Ternary diagram for the relation between $\mathrm{Fe}, \mathrm{Mn}$, and $\mathrm{Al}$ contents of oceanic sediments (after Dymond et al., 1973; Toth, 1980; Karpoff et al., 1988; Karpoff, 1989). $\mathrm{T}=$ terrigenous sediments pole in the upper part of the biogenic oozes field. $\mathrm{EPR}=$ metal-rich deposits from the East Pacific Rise axial zone. Metalliferous sediments field: (1) EPR crest and ridge flanks sediments, (2) Bauer deep surface sediments. $\mathrm{H}=$ hydrothermal deposits field between $\mathrm{Fe}$ and $\mathrm{Mn}$ apices. $\mathrm{Om}=$ interlava flow metalliferous sediments from Oman ophiolite. Nodules $=$ Central East Pacific hydrogenous polymetallic nodules . Same symbols as in Figures 4 and 5.

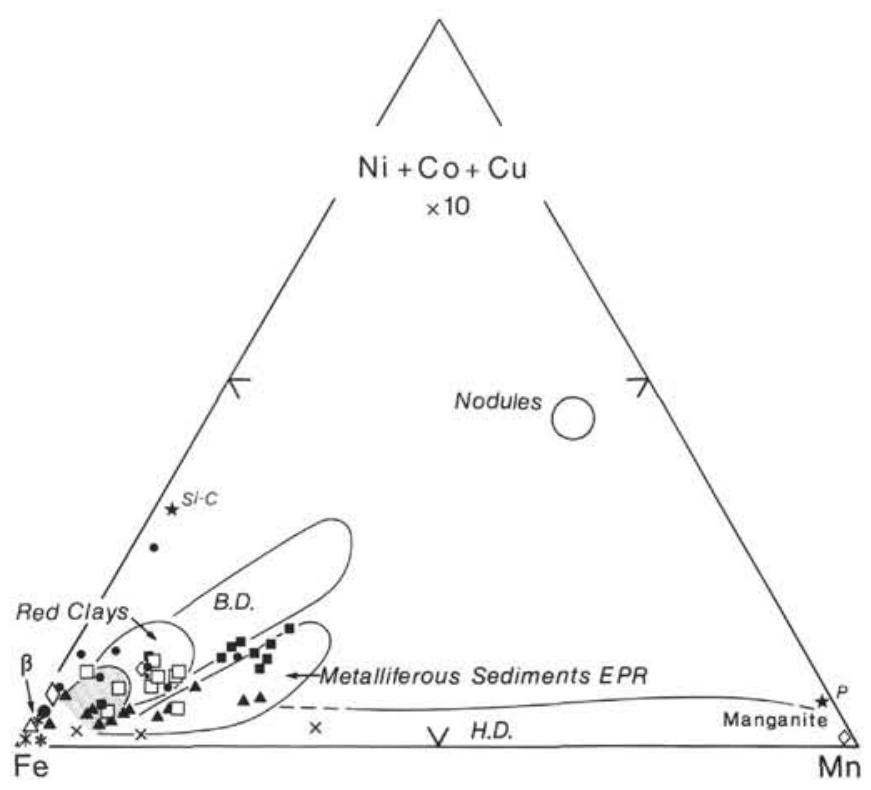

Figure 10. Ternary diagram $[\mathrm{Fe}-\mathrm{Mn}-(\mathrm{Ni}+\mathrm{Co}+\mathrm{Cu}) \times 10]$ (after Bonatti et al., 1972; Toth, 1980; Karpoff et al., 1985; Karpoff, 1989) for lithologic facies from Sites 800 and 801 and their relationship with oceanic facies. H.D. $=$ hydrothermal deposits between $\mathrm{Fe}$ and $\mathrm{Mn}$ apices. EPR = East Pacific Rise basal metalliferous sediments from various sites: from left (higher Fe values) to right (Mn enrichment), deposits from the axial zone, crest sides, and deeper ridge flanks. B.D. = Bauer Deep surface metal-rich sediments and brown clays from the high productivity zone. Red clays = surficial red clays from central East Pacific Ocean and their associated polymetallic nodules (nodules). Lowermost area near $\mathrm{Fe}$ apex $=$ biogenic siliceous and calcareous oozes. $\mathrm{Si}-\mathrm{C}=$ siliceous concretion from Pliocene clayey siliceous ooze at Site 464, DSDP Leg 62. $\mathrm{P}=$ manganese pellet from Paleocene brown clay at Site 550, DSDP Leg 80. Same symbols as in Figure 9. 


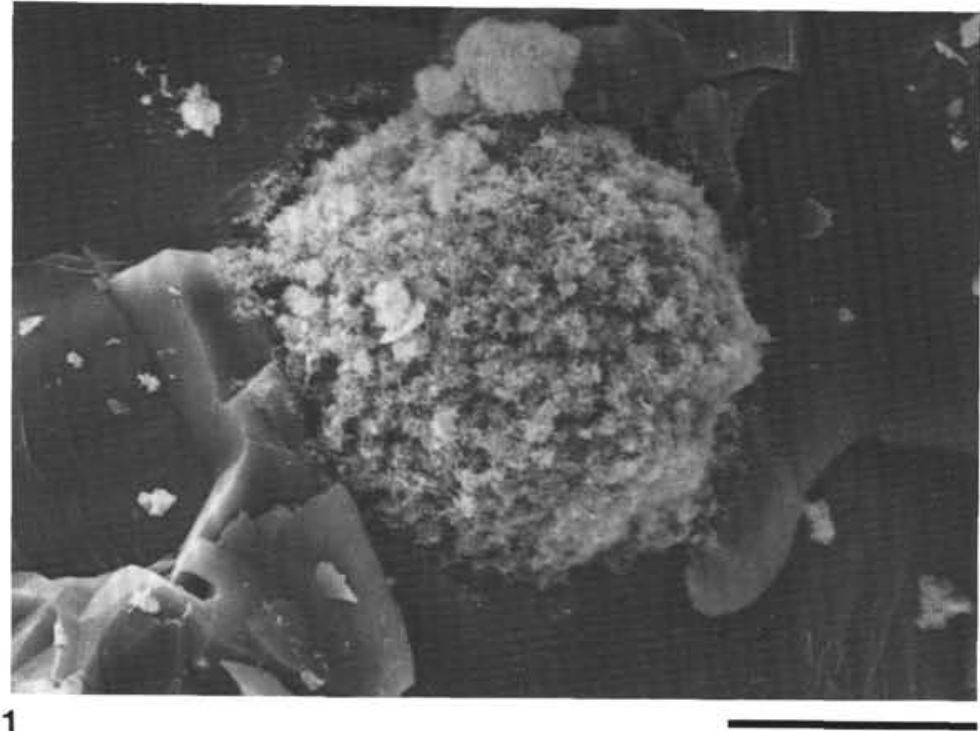

1
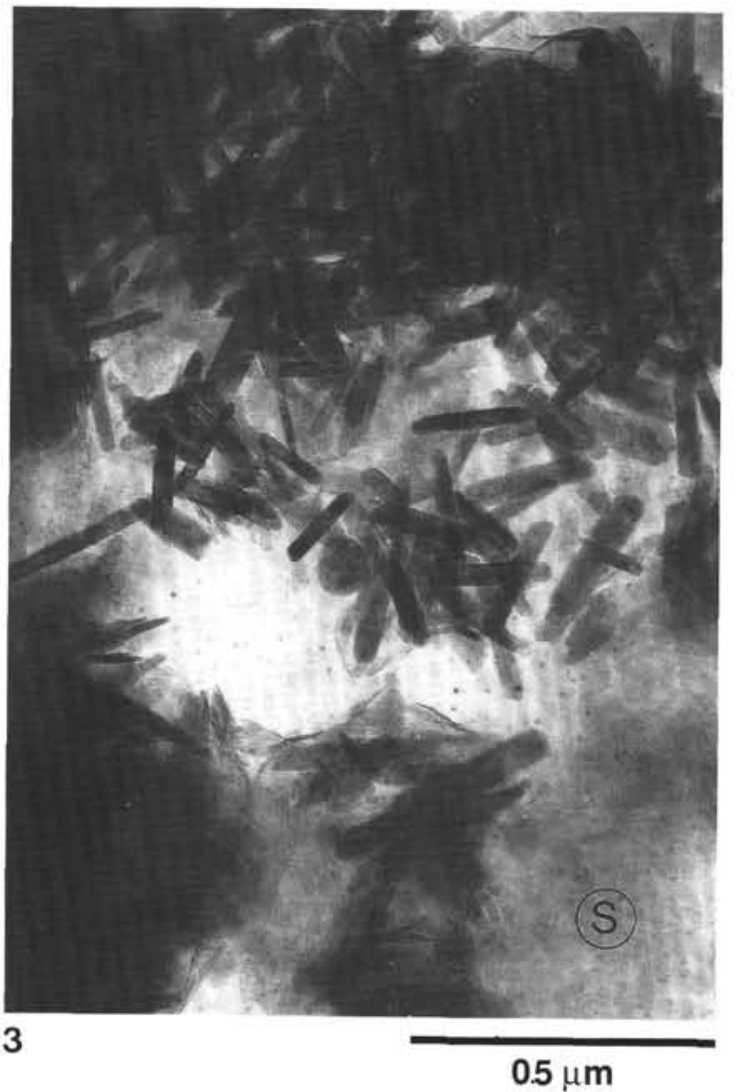

4
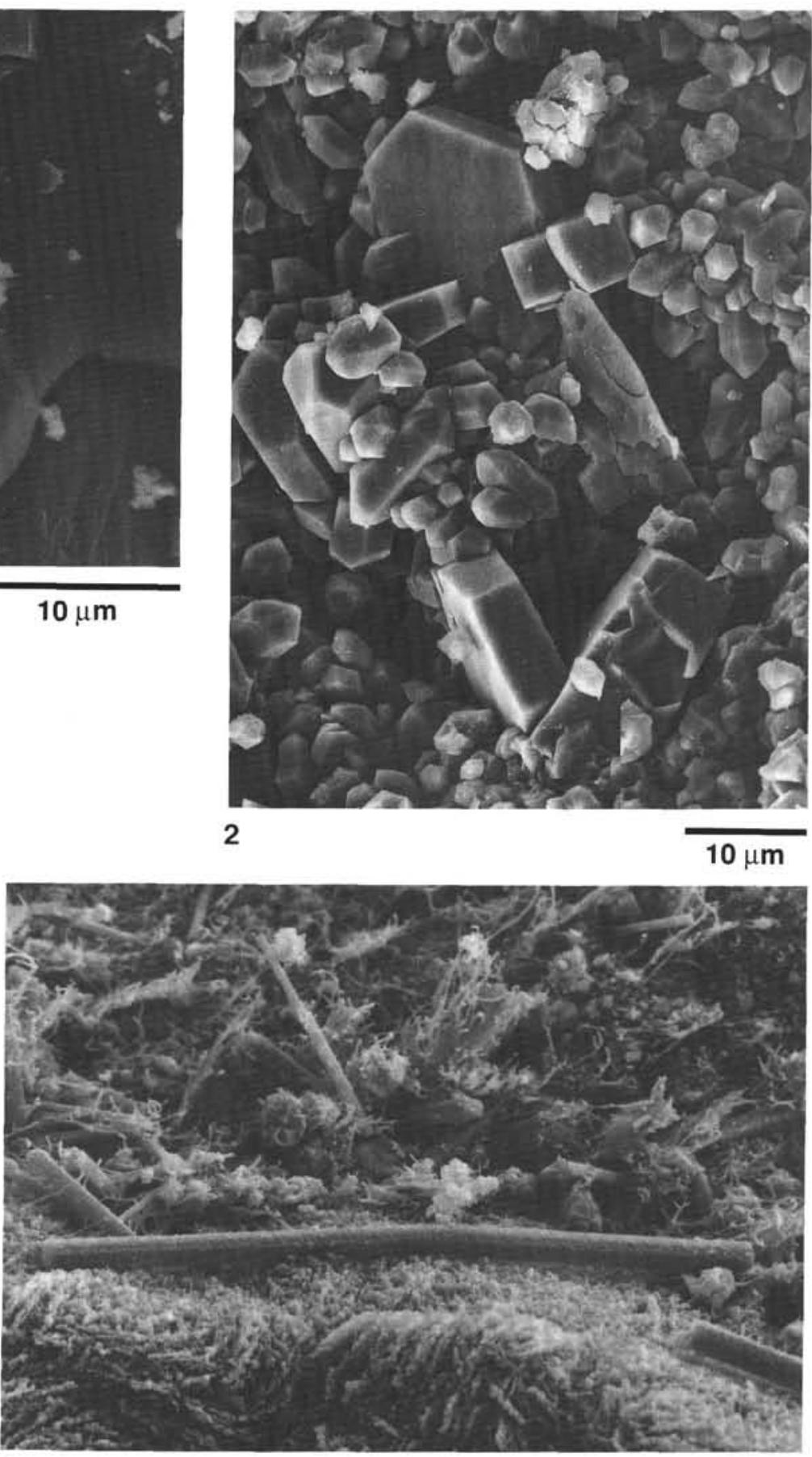

$10 \mu \mathrm{m}$

Plate 1. Jurassic basement and basal deposits at Site 801. 1. SEM photomicrograph of the ochre hydrothermal layer with quartz and goethite globule (Sample 129-801C-4R-2, $101 \mathrm{~cm}$ ). 2. Bipyramidal quartz and larger apatite crystals from the white lamina of the hydrothermal layer (Sample 129-801C-4R-2, 102 cm, SEM). 3. TEM microphotograph of the untreated clay fraction of the basal red radiolarite (Unit V, stage 1; Sample 129-801B-35R-3,1 cm): flaky smectite particles (S) and small iron oxide grains. 4. Valanginian brown radiolarite (Unit IV, stage 2; Sample 129-801B-14R-1, $24 \mathrm{~cm}$, SEM): Mn-oxide rods around opaline lepispheres from a radiolarian test. 


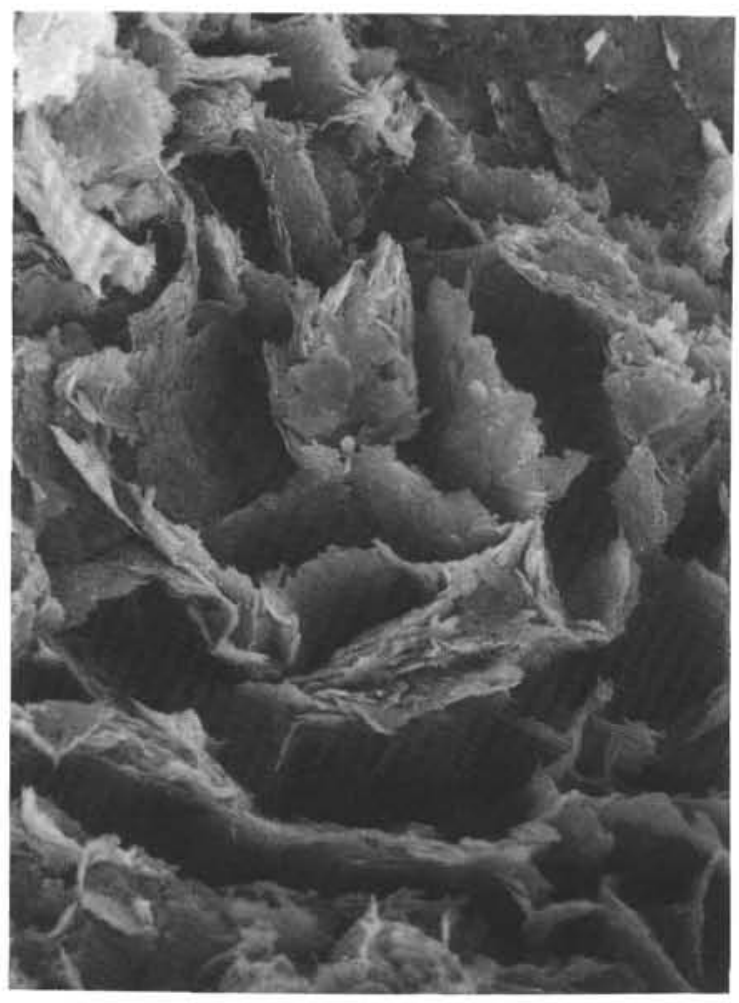

1

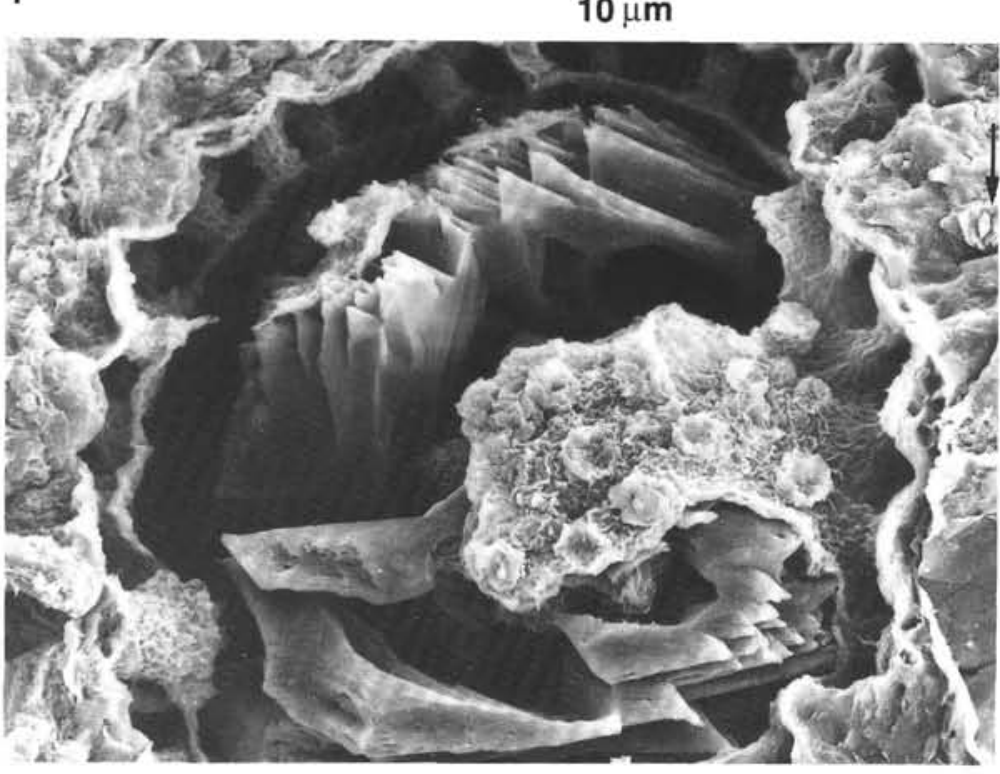

4

Plate 2. SEM microphotographs of the Cretaceous volcaniclastic turbidite deposits (stage 3). 1. Well-crystallized manganite (Site 800, Unit IV; Sample 129-800A-38R-1, 29 cm). 2. Authigenic Mg-rich smectite and K-zeolite crystals (Site 800, Unit IV; Sample 129-800A-41R-1,93 cm). 3. Authigenic honeycomb smectites and small zeolite crystals (Site 800, Unit IV; Sample 129-800A-33R-2, $146 \mathrm{~cm}$ ). 4. Clayey layer in the volcaniclastic turbidite at Site 801 (Unit III; Sample 129-801B-5R-2, $84 \mathrm{~cm}$ ): clay-replaced and quartz-filled radiolarian test and very small clinoptilolite crystals in the matrix (arrow).
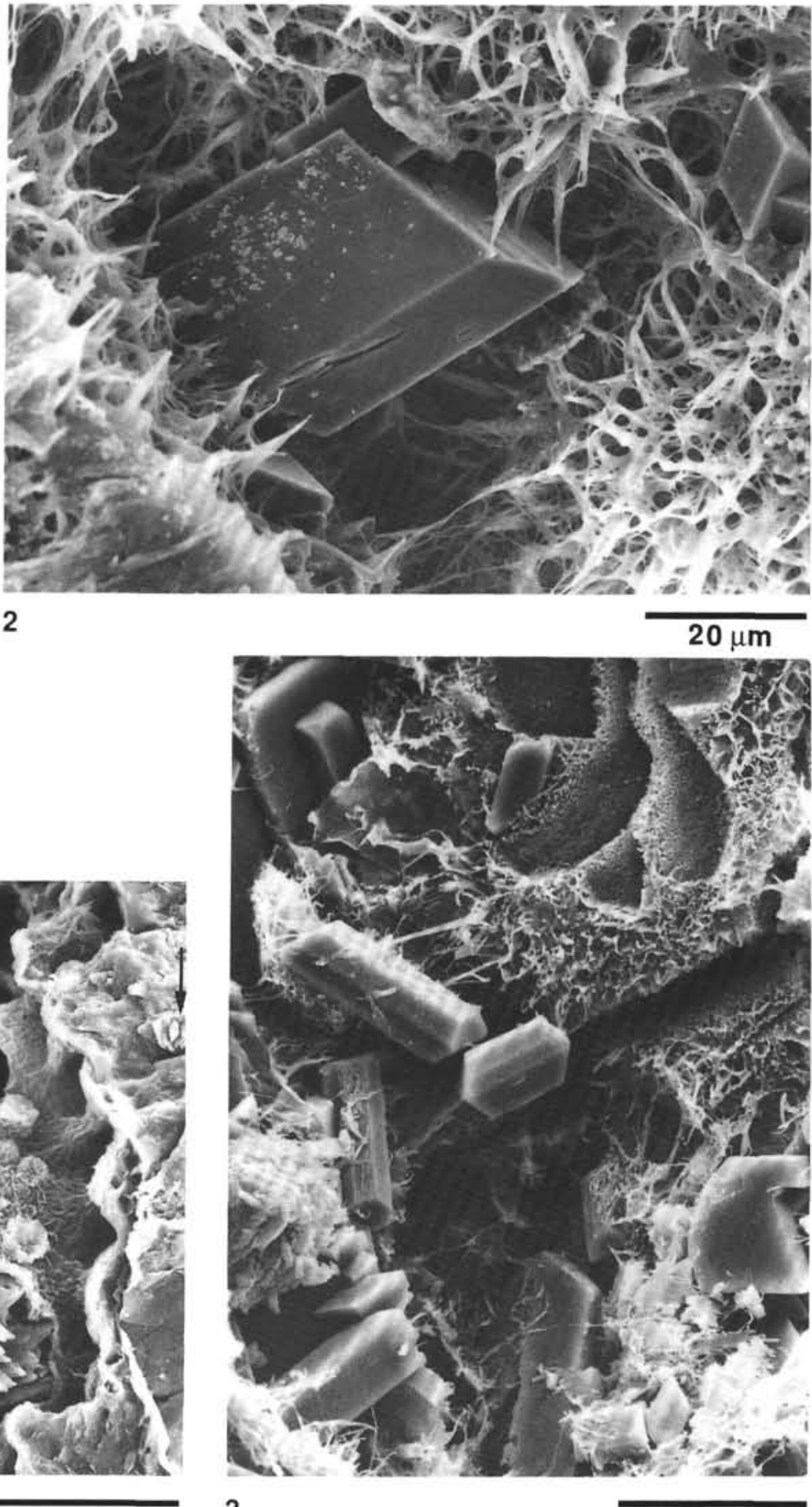

$10 \mu \mathrm{m}$ 


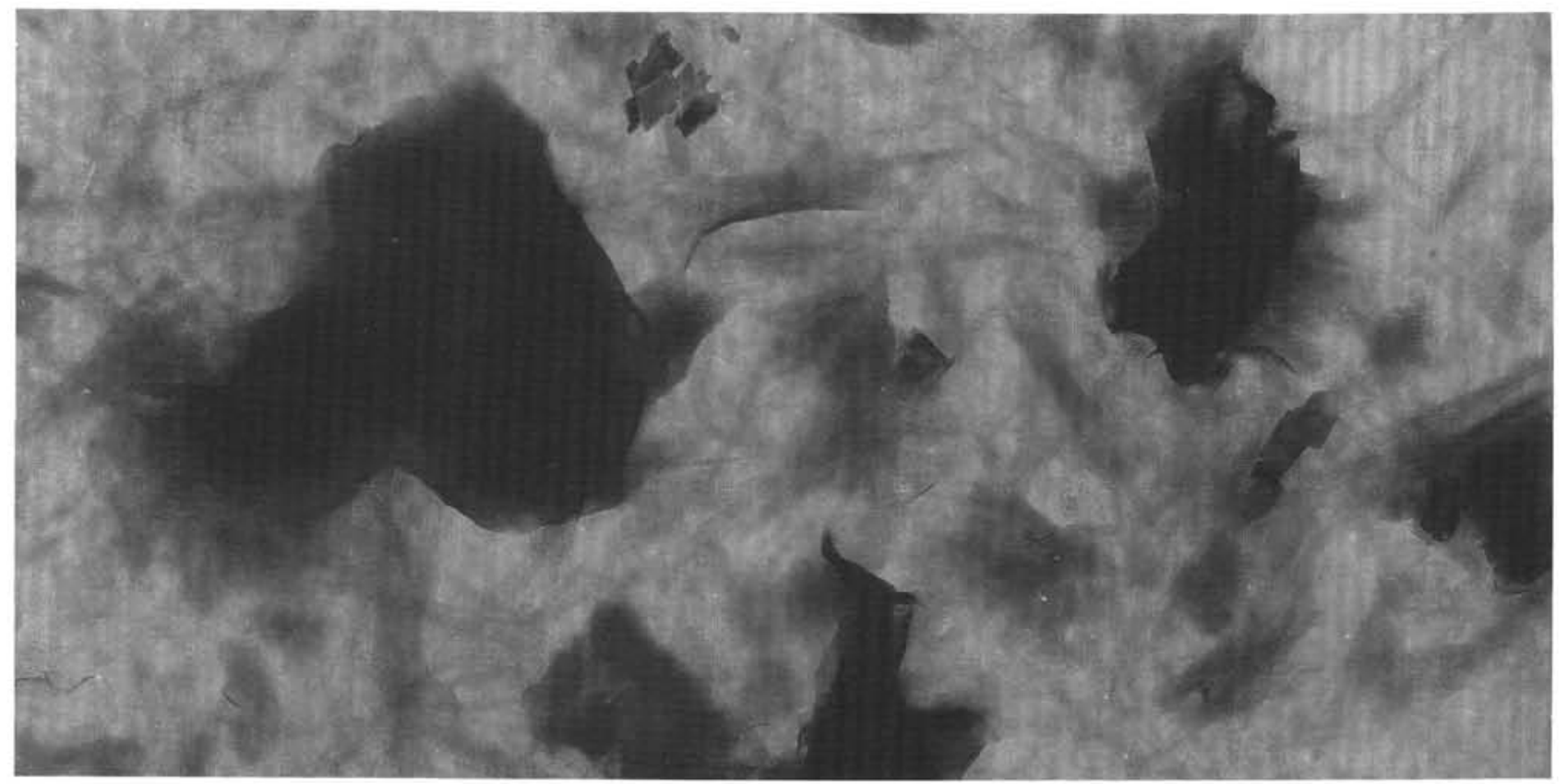

$1 \mu \mathrm{m}$
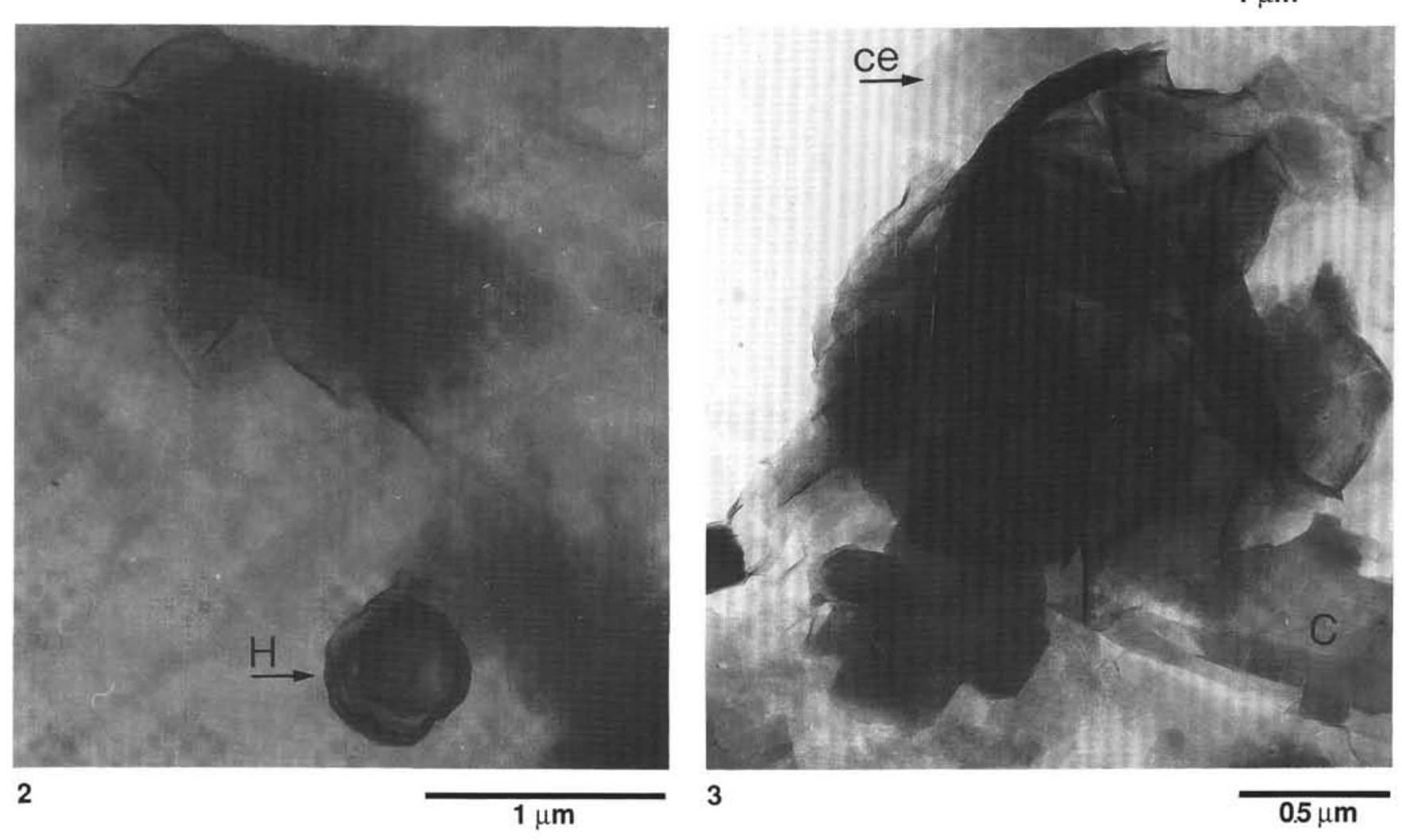

2

$1 \mu \mathrm{m}$

Plate 3. TEM microphotographs of untreated clay fractions $(<2 \mu \mathrm{m})$ of the Cretaceous volcaniclastic turbidite deposits (stage 3 ). 1. The two types of smectite particles with flakes and thin laths (Sample 129-800A-38R-1,12 cm). 2. Flaky particles and diffuse laths of smectite and halloysite cylinder (H) (Sample 129-800A-36R-2, 39 $\mathrm{cm}$ ). 3. Slightly crumpled smectite particle, clinoptilolite fragment (C), and celadonite platelets (ce) in the background (Sample 129-800A-26R-1,4 cm). 

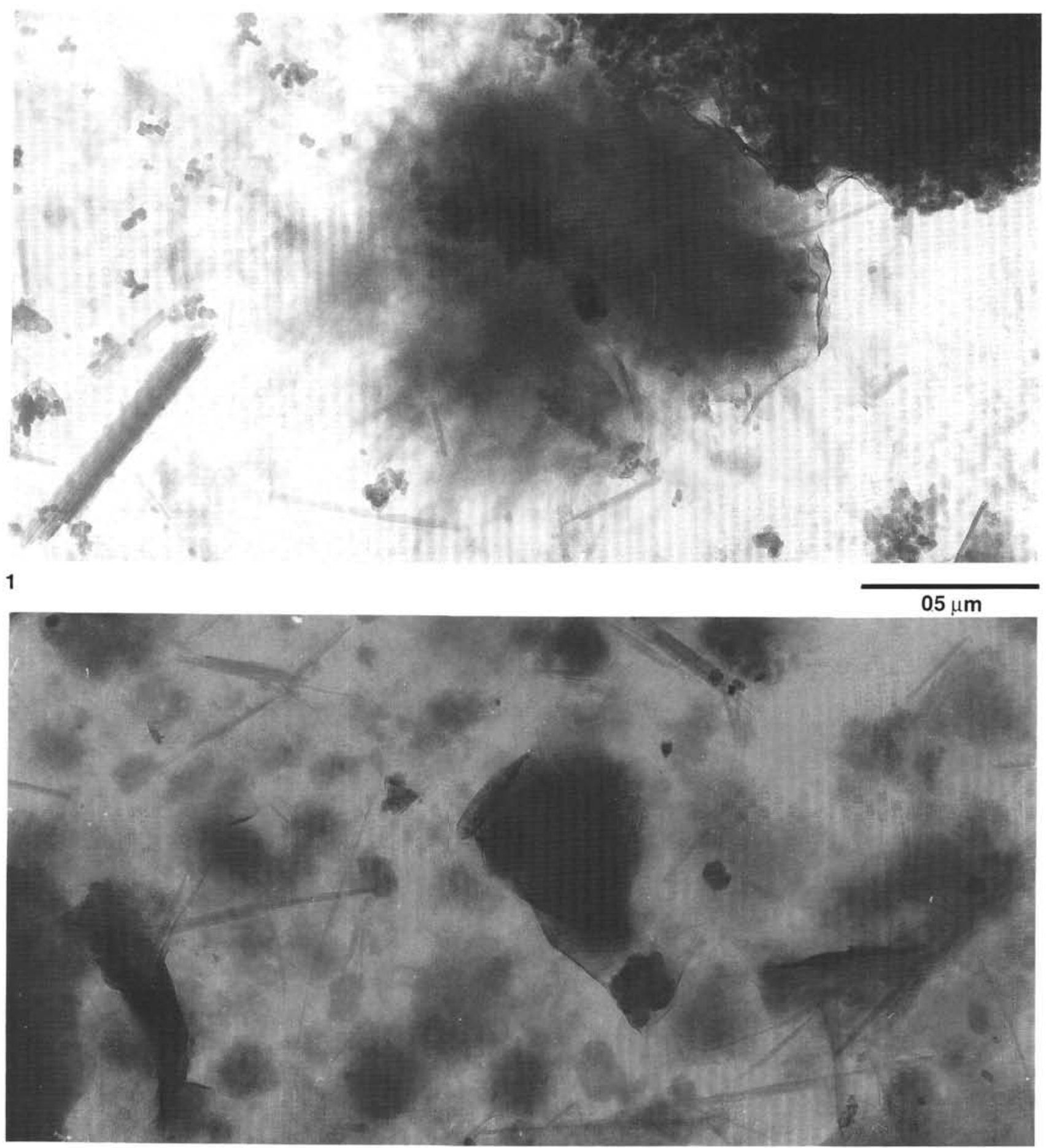

2

Plate 4. TEM microphotographs of untreated clay fractions $(<2 \mu \mathrm{m})$. 1. Late Albian radiolarian chert (stage 4; Sample 129-800A-19R-1, 37 cm): smectite particle with diffuse lath-shaped edges and curled overgrowths commonly observed for authigenic and/or diagenetically transformed smectites, longer laths of palygorskite, and aggregates of siliceous globules. 2. Cenozoic pelagic red clay (stage 6; Sample 129-801 A-7R-1, $27 \mathrm{~cm}$ ): small flaky smectite particles and rare thin and short palygorskite fibers. 